\title{
Market-Based Bank Capital Regulation
}

\author{
Jeremy Bulow and Paul Klemperer*
}

September 2013

The latest version of this paper, and related material, will be at www.paulklemperer.org

\begin{abstract}
Today's regulatory rules, especially the easily-manipulated measures of regulatory capital, have led to costly bank failures.

We design a robust regulatory system such that (i) bank losses are credibly borne by the private sector (ii) systemically important institutions cannot collapse suddenly; (iii) bank investment is counter-cyclical; and (iv) regulatory actions depend upon market signals (because the simplicity and clarity of such rules prevents gaming by firms, and forbearance by regulators, as well as because of the efficiency role of prices).

One key innovation is "ERNs" (equity recourse notes--superficially similar to, but importantly distinct from, "cocos") which gradually "bail in" equity when needed. Importantly, although our system uses market information, it does not rely on markets being "right".
\end{abstract}

*Bulow: Stanford University; ibulow@stanford.edu.

Klemperer: University of Oxford; paul.klemperer@economics.ox.ac.uk.

This paper is based upon an Op-Ed written jointly with Jacob Goldfield, and extensive discussions with him. We also particularly thank Peter Blaustein, lain de Weymarn, Darrell Duffie, Zach Frankel, John Geanakoplos, Andy Haldane, Jeff Horwitz, Thomas Kempner, Antoine Lallour, Will Levine, Ian Martin, Meg Meyer, Pascal Paul, Ken Rogoff, Myron Scholes, Andrei Shleifer, Lawrence Summers, Misa Tanaka, Kevin Warsh, Nancy Zimmerman, and seminar participants at the IMF. Bulow is a member of the Mountain View board of American Century Investment Management Inc. 


\section{Introduction}

Current bank regulatory capital systems fail in three important ways:

First, regulatory capital measures bear little relation to firms' financial health. Financial institutions ranging from Lehman, Wachovia, and Citigroup in the U.S. to Bankia and Dexia in Europe were rated as well capitalized on the day they failed, got bailed out, or were acquired. Dexia passed the 2011 European stress tests with flying colors, with its core equity projected to fall no lower than $€ 15.3$ billion (about 10\%) in the "adverse scenario", just two months before it requested a €90 billion bailout guarantee. Gaming of the regulatory rules distorts both investment decisions and risk-management.

Second, "too big to fail" means the "property rights" in bank losses are not clearly and credibly allocated. We don't know which debt holders will be asked to contribute how much to rescue insolvent institutions. While efforts are being made to make bankruptcy less costly and so more plausible (through e.g. living wills, bail-in, and ring-fencing), it is hard to know whether politicians will allow these mechanisms to operate as planned. It will always be more expedient to push off a default, and sometimes it might even be the right policy. But the consequence is that tail risk gets shifted, both explicitly and implicitly, to citizens who are ill-equipped to bear it. And because regulatory capital rules allow banks to overstate assets, and encourage them to gamble on "mean reversion" in asset prices, taxpayers' losses can be enormous.

Third, the current system is pro-cyclical. Distressed banks (those with little market capital relative to their regulatory capital and liabilities) find it unappealing or impossible to raise the new equity required to make new risky loans, because so much of any equity raised will simply go to reducing the expected losses of the creditors, including the government who is insuring the deposits. So troubled banks contract instead---see, e.g., Europe 2008-present. That is, as we show more fully below, the current regulatory system creates an unusually severe "debt overhang" problem that acts just like a tax on new investment in bad times. ${ }^{1}$

Simply doubling or trebling capital requirements won't do. For example, in 2008-11 the US Federal Deposit Insurance Corporation (FDIC) lost money on 413 bank failures. Say that those banks --- which required 6 percent core tier 1 regulatory equity to be classified as "well capitalized"-- each held an extra 14 percent of assets in cash, but no extra debt on the day they failed. This infusion would have been insufficient to cover losses in 372 (90\%) of these cases. ${ }^{2}$ Of course most of these banks were relatively simple; more complex large banks might have better risk management, but also more scope for trouble.

Furthermore, high capital requirements have costs too, creating incentives to move assets to "shadow banks" and other differently regulated institutions. Moreover, merely changing capital requirements would do nothing about the problems of pro-cyclicality, or the pressures on regulators to relax

\footnotetext{
${ }^{1}$ By "debt overhang" problem, we mean a requirement that new investments be funded with securities that are on average sufficiently junior that wealth is transferred from existing shareholders to creditors (by transferring expected costs of default in this way). In particular, regulatory capital requirements may force a bank wishing to make a new investment to increase its share capital by a sufficiently greater fraction than the fraction by which it increases its debt that the total value of its deposit insurance falls, even though its guaranteed outstanding debt increases-see section $2 b$, and see Appendix 1 for full details.

${ }^{2}$ Source: FDIC Historical Statistics on Banking, as of December 10, 2012.
} 
requirements in a recession. We need to transition to a fundamentally more robust system while banks are temporarily less reliant on government support.

Our solution is based on two rules. First, any systemically important financial institution (SIFI) that cannot be quickly wound down must limit the recourse of non-guaranteed creditors to assets posted as collateral plus equity plus unsecured debt that can itself be converted into equity--so these creditors have some recourse but cannot force the institution into re-organization. Second, any debt guaranteed by the government, such as deposit accounts, must be backed by government-guaranteed securities. This second rule can only realistically be thought of as a very long-run ambition - our interim objective would involve a tight ring-fence of government-guaranteed deposits collateralized by assets that are haircut at rates similar to those applied by lenders (including central banks ${ }^{3}$ and the commercial banks themselves!) to secured borrowers.

Specifically: first, we would have banks replace all (non-deposit) existing unsecured debt with "equity recourse notes" (ERNs). ERNs are superficially similar to contingent convertible debt ("cocos") but have important differences. ERNs would be long-term bonds, subject to certain term-structure requirements, with the feature that any interest or principal payments payable on a date when the stock price is lower than a pre-specified price would be paid in stock at that pre-specified price. The pre-specified price would be required to be no less than (say) 25 percent of the share price on the date the bond was issued. For example, if the stock were selling at $\$ 100$ on the day a bond was issued and then fell below $\$ 25$ by the time a payment of $\$ 1000$ was due, the firm would be required to pay the creditor $(1000 / 25)$ $=40$ shares of stock in lieu of the payment. If the stock rebounded in price, future payments could again be in cash.

Crucially, for ERNs, unlike cocos:

$>$ any payments in shares are at a pre-set share price, not at the current share price or at a discount to it-so ERNs are stabilizing because that price will always be at a premium to the market

$>$ conversion is triggered by market prices, not regulatory values-removing incentives to manipulate regulatory measures, and making it harder for regulators to relax requirements

$>$ conversion is payment-at-a-time, not the entire bond at once (because ERNs become equity in the states that matter to taxpayers, they are, for regulatory purposes, like equity from their date of issuance so there is no reason for faster conversion)--further reducing pressures for "regulatory forbearance" and also largely solving a "multiple equilibria" problem raised in the academic literature

$>$ we would replace all existing unsecured debt with ERNs, not merely a fraction of it-ensuring, as we show below, that ERNs become cheaper to issue when the stock price falls, creating countercyclical investment incentives when they are most needed.

Creditors could still acquire short-term unsecured (i.e., non-collateralized) bank debt in much the way they can acquire short-term debt from, say, mortgage securities. Investment trusts could purchase ERNs and pool and tranche them, issuing more senior and shorter-term claims to those who want them. The difference is that in a panic, which might cause an investment vehicle to sell some of its bonds to pay short-term claims, losses would be borne by those who took levered, junior claims in the trust without any short-term repercussions for the underlying banks' financial condition. Furthermore, investors who

\footnotetext{
${ }^{3}$ See for example the Federal Reserve Discount Window and Payment System Risk Collateral Margins Table and the Bank of England Summary of haircuts eligible for the Bank's lending operations.
} 
wanted to reduce or eliminate the tail risk of their ERNs could do so by buying equity puts. They could transfer the risk to any willing buyer-just not to the taxpayer.

Furthermore, secured (i.e., collateralized) borrowing by banks would also undergo a subtle but crucial transformation. Currently a secured creditor has a claim against the posted assets plus an unsecured claim against the bank for any shortfall, should the asset be insufficient to cover the debt. If there is a good chance that the government will bail out a failing bank the terms of the loan will be based partially on the government's credit rather than on the quality of the bank's. The solution is to limit the recourse that a creditor would have, beyond the posted collateral, to either shares of stock or ERNs.

Second, in our ideal world, deposit accounts would follow a money market fund model. Government guaranteed accounts would essentially be like existing money market funds that invest in governmentguaranteed debts, along the lines of $100 \%$ reserve proposals. Currently, depositors in effect receive short-term government-guaranteed debt, acquired from banks that obtain it in return for unsecured bank debt plus mispriced, cheap, deposit insurance. We would eliminate the "middle man", so that depositors directly hold loans from the government, and banks place their unsecured debt with investors who are willing (and allowed) to bear risk. ${ }^{4}$ Non-guaranteed accounts would operate like money market funds, with rules akin to those proposed by the US Securities and Exchange Commission in 2012. Similar principles could be applied to the funding of derivatives and other potential liabilities.

Our system generates strong countercyclical pressures:

$>$ debt payments automatically convert to equity in times of stress, so automatically repair the capital structure

$>$ ERNs become cheaper to issue when the stock price falls. If, e.g., the stock price declines from 100 to 40, new ERNs can be issued with a conversion price of 10 instead of 25-so the new bonds will only suffer losses after the old bonds have already taken a 60 percent haircut. The more the stock price declines the more senior new issues can be; if a stock hits a low new, ERNs will be senior to all other unsecured capital and so especially cheap to issue

$>$ issuing new senior debt (ERNs) can send a better signal about the company's prospects than selling assets, because issuing ERNs is relatively cheap; by contrast, raising new funds in the existing system is a worse signal than selling off assets, because of the need to raise equity to maintain its regulatory-capital ratio

$>$ the existing system's "debt-overhang" problem that acts like an investment tax in bad times is reversed.

Because all creditors' final recourse is to ERNs--which become equity in bad world-states--our system alleviates liquidity as well as solvency problems. So our system also mitigates "downward spirals" and liquidity crises, while allowing poorly-run firms to gradually fail.

\footnotetext{
${ }^{4}$ An interim ring-fence proposal would not achieve this but if, as we envision, other liabilities are excluded from the ring-fence, then at least the taxpayer would be insuring something like secured debt instead of unsecured debt. In our system, ring fencing is not so much a way of limiting the activities of commercial banks as a way of reducing banks' reliance on deposit insurance--we are closer to the U.K. Independent Commission on Banking (2011) in this regard than we are to some other proposals aimed at separating retail banking. Importantly, in our system, making deposits safe ensures that countercyclical ERNs can be issued in bad times.
} 
Banks will still fail in our system--just not as fast. While the ability to issue senior debt in bad times can help a firm stay in business for longer, new investors will know that they can become junior in the future too, so poor firms inevitably peter out. The difference is they fail with a whimper rather than a bang.

There have been many proposals to add ever-more elaborate regulations to a baroque regulatory system that has already proved unmanageable. We propose instead to make things much simpler. ERNs are a counterweight against pro-cyclicality. Jettisoning complex capital rules, and simply transferring tail risk back where it belongs -- with private investors, takes taxpayers off the hook and ensures that banks with profitable opportunities can use them. We proceed as follows: section 2 discusses the current dysfunctional regulatory system in more detail. Section 3 outlines our new proposed market-based system. In section 4 we explain how our system mitigates "downward spirals" and liquidity crises while allowing poorly-run firms to gradually fail. Section 5 describes how ERNs would have worked in the financial crisis, and how they would affect bond yields and capital structure. We discuss the relationship between our plan and other proposals for reform in section 6 .

Finally, section 7 discusses transition to our system. In the short run, some of the features of our ERNs could improve the existing design of cocos; in the medium-term, a full transition to ERNs, ideally in conjunction with "ring fencing", would substantially stabilise the financial system even prior to the full implementation of our plan. Section 8 concludes.

\section{Failures of the Current Banking Regulatory Capital System}

While regulatory systems differ around the world, existing and--under current plans-likely future regimes of the U.S., the U.K., and the Eurozone, among others, suffer from a similar set of general problems. In particular:

- Regulatory capital is a poor measure of firms' financial health. Accounts are (legally) manipulated, incentives are distorted, and losses may not be confronted until well after a bank has become insolvent.

- The systems generate pro-cyclical investment incentives in bad times.

- Regulators have incentives to forbear from implementing the rules.

- Large amounts of risk are inefficiently allocated to taxpayers.

While the details differ, and many of the specific difficulties we mention below may not be too hard to fix, these general features seem inherent in regulatory regimes modeled on current lines.

\section{a. Regulatory Capital Measures vs. Banks' Financial Health}

The regulatory capital system reflects changes in financial health very slowly at best. As Haldane $(2011)^{5}$ has shown, financial institutions that fell into crisis maintained regulatory capital ratios that were solid as a rock, right to the bitter end. Bear Stearns and Washington Mutual, to take two examples, held large excesses of regulatory capital on the days they failed. ${ }^{6}$ Bankia, chaired by the former head of the IMF, reported 9.9 percent "core tier 1" equity (€16 billion) until May 2012 when it announced the need for a

\footnotetext{
${ }^{5}$ See especially charts 5 and 6 .

${ }^{6}$ For Bear Stearns, see for example "Chairman Cox Letter to Basel Committee in Support of New Guidance on Liquidity Management". For Washington Mutual (and Wachovia) see e.g. Rosengren (2011) Fig. 1.
} 
$€ 19$ billion bailout. Meanwhile, the 2010 European stress tests indicated that no privately controlled bank required additional capital, ${ }^{7}$ and the U.S. Federal Reserve's "stress tests" assessed only whether banks I had enough regulatory capital to avoid being closed by regulators over the next two years, not whether they were solvent. ${ }^{8}$

Bank equity levels, the numerator in determining capital ratios, are subject to manipulation (see e.g. Laux and Leuz (2010) and Ellul et al. (2012)), with different banks using significantly different valuations for identical assets (see Table 1). ${ }^{9}$ At the end of June 2008, fundamentally insolvent RBS reported the second-highest total capital ratio of the five large UK banks, and the highest tier 1 ratio, just four months before its $£ 37$ billion bailout. ${ }^{10}$ While RBS would have had a lower capital ratio than others, given its portfolio, under Basel III standards, regulatory arbitrageurs will of course game the system in other ways when these new standards are actually implemented.

Risk weighted assets (RWA), the denominator for computing capital ratios, are also manipulated, or at least subject to tremendous discretion. ${ }^{11}$ Regulators are asked to do an impossible job in determining the valuations and risk weights of trillions of dollars of assets, only a small percentage of which trade directly on liquid markets. In reality, regulators rely on banks' internal models and the reports of credit rating agencies. ${ }^{12}$ A modeling change for JP Morgan caused it to halve its estimated "value at risk" (VAR)

${ }^{7}$ A bank $77 \%$ owned by the Greek government, several cajas controlled by regional governments in Spain, and one German bank already in receivership were told to raise small amounts of capital. The 2011 tests were tougher but have been met with skepticism because of the limited reserving against sovereign defaults. For test results see Committee of European Banking Supervisors (2010, 2011).

${ }^{8}$ Consider the Federal Reserve's (2012) stress tests: while the declines in the equity (59\%) and housing (20\%) markets and the increases in unemployment (to 13\%) considered in the stress tests ${ }^{8}$, combined with the assumption of no changes in capital distributions, would almost surely make many or most large banks insolvent on a market value basis, for the purposes of the stress tests the tier one equity capital of those banks would only decline by an (equally weighted) average of about 3.8 percent of assets. Risk-weighted equity capital ratios may fall both because of losses and because of increases in the risk weight applied to assets as they become less safe. However, calculations of regulatory capital for a fixed portfolio of assets can vary tremendously depending on a bank's internal models --- and be quite unrelated to the bank's underlying financial strength (Haldane, 2011).

${ }^{9} \mathrm{AIG}$ (2008) gives many examples. Commercial banks appear to be more aggressive than investment banks, perhaps because of the regulatory regime: while some investment banks surely overstated their assets' values in the crisis, they marked them much less aggressively than the commercial banks. The probable reason is that, in the absence of deposit insurance, a reputation for marking to market commits to raising more equity when there are losses and so permits cheaper borrowing. It is notable that it was the commercial banks that lobbied against fair value and mark to market accounting, even though it affected far more of investment banks' assets.

So while commercial banks will not get into trouble as quickly as investment banks, because their government guarantees let them get away longer with their asset marking, they have the potential for enormous losses relative to assets.

${ }^{10}$ See FSA Board Report (2012) p. 195.

${ }^{11}$ See Haldane (2013), Mariathasan and Merrouche (2012), and Basel Committee on Banking Supervision (2013), in which Table 10 shows that for the same hypothetical portfolio banks' estimates of their capital requirements ranged from 13.4 (million euros) to 34.2.

12 "The OCC doesn't validate every specific model, it validates the framework by which the institutions construct and validate their own models... it is not possible to dig deeply into each model" according to a 
in the first quarter of 2012, in the midst of suffering a $\$ 6$ billion loss on its infamous "London Whale" trades. ${ }^{13}$ In 2007 Deutsche Bank allegedly failed to recognize up to $\$ 12$ billion in losses, representing a quarter of its regulatory capital, by not recognizing increased counterparty risk in a set of derivatives trades; the bank reported a tier 1 capital ratio increasing from 8.6 percent to 10.1 percent between 2007 and 2008, even as the bank's ratio of accounting equity to total assets fell from 2 percent to $1.4 .{ }^{14}$ Minimum leverage ratios effectively assign all assets an equal risk weight, and so when binding create incentives to shift portfolios from treasury bills to junk bonds and stock options.

According to Federal Deposit Insurance Corporation (FDIC) data, the nine years in which United States banks have had the highest ratios of equity to assets in the last 70 are 2004-2012--- not exactly the Golden Age of bank capital adequacy. ${ }^{15}$ Based on the ratio of risk-weighted assets to assets, U.S. bank balance sheets steadily contained less risk from mid-2006 (75.90\%) to the end of 2010 (66.96\%), and the total Tier 1 capital of U.S. commercial banks has risen every year in this century.

The regulatory system distorts incentives in several ways. One of the motivations for Citigroup to sell out of Smith, Barney at what was generally believed to be a low price, was that it allowed Citi to book an increase in regulatory capital. Conversely, selling risky "toxic assets" with a regulatory value greater than market is discouraged because doing so raises capital requirements even while reducing risk. ${ }^{16}$

former senior regulator at the Office of the Comptroller of the Currency (OCC), quoted in Carver and Watt (2012).

${ }^{13}$ See Carver (2012). "[A]nalysts were told that the [CIO] analysts were told the unit changed its VAR model at the start of this year, only to change it back again at the end of the first quarter. When the old model was reinstated, JP Morgan's average VAR for the first three months of 2012 leapt to $\$ 129$ million - almost double the $\$ 67$ million disclosed in the bank's first-quarter earnings". According to the J.P. Morgan Management Task Force Review (2013), a review of the model uncovered "an operational error in the calculation of the relative changes in hazard rates and correlation estimates. Specifically, after subtracting the old rate from the new rate, the spread sheet divided by their sum instead of their average, as the modeller had intended. This error likely had the effect of muting volatility by a factor of two and of lowering the VaR...." (pp. 128-29) While errors in complex calculations are always a risk, it seems likely that if an error had doubled rather than halved J.P. Morgan's VAR the error would have been found before the model was employed.

${ }^{14}$ See Plender (2012). Note that because of differential accounting treatment Deutsche Bank would have reported the same amount of equity but only about half as many assets in the U.S. as in Europe. We do not claim any insight into whether Deutsche Bank's books should or should not have been marked down.

${ }^{15}$ See FDIC Historical Statistics on Banking, Table CB14.

${ }^{16}$ Liquidity reduction is another consequence of the current regulatory system, as firms will avoid pricediscovery by avoiding buying as well as selling over-marked assets. For example, Goldman Sachs stood ready to sell assets at marks that AIG protested were too low, but AIG did not take up these offers. See Goldman Sachs (2009). For an example of traders not buying even though they claimed the price was too low, see the FCIC transcript of a July 30, 2007 telephone call between AIG executives. "We can't mark any of our positions, and obviously that's what saves us having this enormous mark to market. If we start buying the physical bonds back ... then any accountant is going to turn around and say, well, John, you know you traded at 90, you must be able to mark your bonds then." Duarte (2012) discusses the recent trend of European banks to meet their requirements to raise regulatory capital by repurchasing their own junk bonds, arguably increasing the exposure of government insurers. 
The regulatory system also distorts banks' choices about which businesses to participate in. For example, under Basel II publicly traded, unhedged, equity is assigned a 300 percent risk weight, so a capital requirement of 24 percent if the bank needs to hold capital equal to 8 percent of risk weighted assets. ${ }^{17}$ Even at the height of the financial crisis it was possible to borrow 90 percent of the value of a publicly traded portfolio from a money market fund, so the market capital requirement was only 10 percent. Uncollateralized commercial loans are arguably economically more risky but have only a 100 percent risk weight, so even if assets were marked to fair value there would be a bias towards commercial loan risk remaining in banks, because of the implicit government financing. JP Morgan CEO Jamie Dimon told securities analysts "The way Basel III is set up, certain products have much higher capital charges than others. And so we have choices and options to make...we can just sell things or hedge them differently and that could make a difference. So yes, we're going to manage the hell out of RWA." ${ }^{18}$ Banks also have an incentive to hold illiquid hold-to-maturity assets that will be systematically mis-marked in a downturn, rather than assets which might have less economic risk but more accounting risk. $^{19}$

The regulatory system's incentives to avoid loss recognition also distort risk management and the information available to senior management. The profitability and risk of mortgage securitizations was overestimated because of the mis-valuation of unsold securities and the assumption that highly rated securities were nearly riskless--Citigroup and Merrill Lynch were almost destroyed by the huge holdings of AAA rated subprime securities that they were having difficulty selling, but it appears that so long as these securities were kept on the books at 100 some key decision makers were unaware of their exposure. ${ }^{20}$

While bad accounting can't help a non-financial firm avoid financial distress, banks, especially commercial banks, are "protected" in various ways. First, commercial bank deposit insurance is heavily subsidized, especially for weaker banks. ${ }^{21}$ Second, other rules and institutions also make it easier for

${ }^{17}$ For risk weights see Department of Treasury et al. (2012). "Basel III" documents are available from the Bank for International Settlements (BIS).

${ }^{18}$ See JP Morgan Chase's Q3 2011 Earnings Call Transcript. Or "the guys putting on trades figure out the weaknesses in the new VAR model, and put on positions that do not result in increased modelled risks", as one observer quoted in Carver (2012) suggested.

${ }^{19}$ In fact, the over-optimistically marked assets that banks have incentives to hold may be especially risky if their "toxicity" is due to a decline in the value of their underlying collateral-see section $2 \mathrm{~b}$.

${ }^{20}$ McLean and Nocera (2010) document, for example, that estimates of Merrill Lynch's subprime exposure provided to CEO Stan O'Neal assumed that there was no risk in its AAA holdings, and he did not know how the calculations were being made.

${ }^{21}$ Government-provided insurance on the investments of depositors and other creditors is both grossly underpriced, and also mispriced - it is not appropriately risk rated, either across banks, or across the cycle. The enormous gaps between regulatory and market capital automatically imply distortions even if insurance premia are high enough to let the insurer break even over the cycle. For example, at the end of 2011 the FDIC based its assessments on \$11.99 trillion of liabilities, calculated as total assets less tangible equity, including $\$ 6.98$ trillion in insured deposits. Total assessments for 2011 were $\$ 13.50$ billion, or .1125 percent of the liability base. Only 206 of the 813 institutions on the FDIC "problem list" paid assessments of more than 25 basis points; just 27 representing 0.28 percent of the asset base paid more than 35 basis points. See FDIC Quarterly (2012). By contrast, as of December 14, 2012 the credit default swaps of the two safest U.S. banks, Wells Fargo and J.P. Morgan, traded at 77 and 90 basis points respectively. Similarly, the UK's deposit insurance, i.e., the Financial Services Compensation 
troubled banks to access additional government-guaranteed funds. In the U.S., for example, unsecured borrowing could easily be replaced by lending from the Federal Home Loan Banks, because the FHLBs receive priority over the FDIC in bankruptcy. From June 30, 2007 until September 30, 2008 FHLB borrowing expanded from $\$ 608$ billion to $\$ 911$ billion. ${ }^{22}$ Banks are also allowed to offer premium (though capped) interest rates to attract "brokered deposits", which have historically represented a disproportionate share of the balance sheet of troubled U.S. banks. ${ }^{23}$ Also important, some larger banks receive some of their funding in the short-term unsecured debt market, and the slow adjustment of regulatory capital can allow these banks to borrow debt that is theoretically risk-bearing, but in fact has time to exit prior to a regulatory default.

Laux and Leuz (2010) and the SEC (2008) provide evidence that the limited use of fair value accounting for commercial banks did not cause the financial crisis. We would go further and argue that inadequate accounting for losses made things worse.

\section{b. Pro-cyclicality}

The sclerotic response of regulatory capital to changes in market capital, combined with implicit and explicit government guarantees, allows banks to avoid recapitalizing when moderate market losses are suffered. In the short run, firms not being pressed to repair balance sheets can smooth shocks. ${ }^{24}$ But, especially because (as described above) the rules encourage banks to hold on to those assets whose market values are furthest below their regulatory values, banks face increasing difficulties if losses then become large. ${ }^{25}$

The problem is that large divergences between regulatory and market capital create a severe "debt overhang" problem, strongly deterring both capital raising and risk taking. When a bank is constrained

Scheme, is funded by levies on banks that are independent of bank risk, and limited in that a bank cannot be required to pay an amount such that it and all previous amounts paid by the bank amount to more than $0.3 \%$ of the bank's protected deposits (according to section 6.3.5 of the FSA handbook).

${ }^{22}$ Because of FHLB priority a bank would have to lose more than it held in deposits for the FHLB to lose money, even if it accepted inferior collateral. (See Federal Home Loan Bank Office of Finance (2013) for current collateral rates.) Of course, when FHLB loans replace unsecured debt, risk is transferred from private creditors to the taxpayer.

${ }^{23}$ See FDIC (2011). Practice differs across jurisdictions. According to the European Central Bank (2002), "In the United States, banks sometimes rely on brokered deposits.... They can represent consistent and heavy borrowings by institutions that have only a limited access to the borrowed funds market, to support unsound an (sic) expansion of the loan and investment portfolios. Brokered deposits, however, are of significance in virtually none of the EU countries. But in the UK, such deposits have always been a significant factor... In BE, IE and NL, the phenomenon exists, but is in practice limited".

${ }^{24}$ By contrast, uninsured firms face pressure to repair their balance sheets by raising equity and reducing assets and risk when asset values fall (more specifically, when the value of existing assets as collateral falls). Because a bank has unsecured creditors who do not have an incentive to run in bad times, or even to monitor its finances, the pressure on the bank comes from regulatory requirements instead.

${ }^{25}$ The sale of an asset with a market value of 30 and a mark of 60 increases the regulatory requirement for a bank to raise equity, even if the sale actually reduces risk. For example, Merrill Lynch's sale of risky mortgage securities that it had marked at $\$ 11.1$ billion to Lone Star for $\$ 6.7$ billion (and lending Lone Star $3 / 4$ of the price on a non-recourse basis) had to be booked as a reduction in regulatory capital, and Merrill simultaneously announced a capital raise. See for example Keoun and Harper (2008). 
(only) by its regulatory capital requirement, new investment requires it to increase regulatory equity in proportion to assets. The lower the market value of assets relative to the regulatory value, therefore, the greater the proportionate increase in equity required for any increase in assets. For example, if a bank's shares are selling at 2 and its assets are marked at a regulatory value of 10, then marginal investment requires increasing equity by 10 percent for every 2 percent increase in total assets. Just as for an unregulated firm, the larger the relative increase in equity, the more risk is removed from creditors (in this case the government who insures the bank's liabilities), and the more existing shareholders are hurt. So for distressed banks with low asset market values, the regulatory system acts just like a tax on new investment.

The debt-overhang effect is more complicated when, as has been the case, the government insures liabilities at a price that is not adequately adjusted for risk. We show in Appendix 1 that in this case the marginal subsidy to new investment peaks when the market value of assets equals the regulatory value $^{26}$, so the system gives mildly counter-cyclical investment incentives when market values exceed regulatory values. But when the market value of assets falls below the regulatory value marginal incentives become pro-cyclical and in very bad times the effect in the previous paragraph is the important one, so even though insurance has a larger and larger value as asset prices fall there is also a larger and larger tax on marginal investment. ${ }^{27}$

The large debt-overhang effect for distressed banks is compounded by a further problem. A decline in the value of the collateral backing a loan not only reduces the value of the loan but also increases its risk. ${ }^{28}$ So even if old loans that have become more risky are marked to market, if their risk weights are not appropriately updated, then these loans will allow the firm to bear more risk per dollar of equity (and transfer more risk to the government) than will new loans. This creates a bias to retaining old loans (which place more risk on the insurer) rather than selling the old loans and originating new ones. Furthermore, an increase in the riskiness of old debt will reduce the incentive to make new investments with historic levels of risk if the additional riskiness increases the probability of a default; see Appendix $1^{29}$

Furthermore, in part because of a regulatory system that allows commercial banks to raise money on the basis of a government guarantee rather than their own strength, financial firms have a reputation

\footnotetext{
${ }^{26}$ Because of the deposit insurance subsidy the market value of the firm will exceed the regulatory value when the market value of assets equals the regulatory value.

${ }^{27}$ An unregulated bank with the same assets and liabilities and with debt covenants that restricted new financing in the same way would face an even bigger disincentive to raise money, because it would not be able to raise its new debt at a subsidized insured price, but all else will not be equal. Without the tax payer guarantee, banks funded by unsecured short-term debt would be compelled to raise additional equity well before the market value of assets falls below liabilities, while deposit insurance is so valuable to banks, and so distorting in incentives, precisely because they will not be so compelled.

${ }^{28}$ For example, say a bank had made an old non-recourse loan of 80 against collateral worth 100 . If the collateral's value fell to 50, the bank would then effectively own the asset and all the risk associated with it. A new loan against similar collateral might only be for 40 , so might require less equity per dollar of value.

${ }^{29}$ Not every firm that has suffered large losses will opt to increase risk if given the opportunity. If management is more concerned about avoiding bankruptcy instead of maximizing expected shareholder returns, it may be biased towards disposing of or retaining riskier assets depending on how dire the situation is.
} 
for being particularly difficult to understand. ${ }^{30}$ This magnifies the usual signaling problem of raising equity. ${ }^{31}$ The problem is exacerbated if regulatory capital is manipulable, because even equity raises made to meet regulatory requirements may be thought to be voluntary. So selling new equity is expensive for signaling reasons, and especially so in bad times. ${ }^{32}$

The pro-cyclicality of the current system is not only damaging, per se. It also contributes to the system's lack of credibility, by accentuating the pressures for regulatory forbearance.

\section{c. Regulatory Forbearance}

Even when rules for the allocation of losses and the determination of regulatory capital adequacy are clearly defined, will regulators and politicians stick to them?

The slow incorporation of market losses into regulatory capital means that by the time regulators can act, an insured firm may already be deeply insolvent. It also means that even when debt is nominally junior to deposits (as is currently the case in the U.S. and is planned in the U.K. ${ }^{33}$ ), short-term unsecured debt can front-run the deposit insurer, leaving the government holding the bag for losses. So by the time regulators are confronted with the choice of closing an insolvent bank, the set of protected liabilities may extend well beyond core deposits and fully collateralized debt. The regulators then face the choice of closing the bank, injecting new equity capital, or "kicking the can down the road" by forbearing and guaranteeing new debt. Since tax payers are hurt regardless, it may often be most efficient to forbear, either by changing the rules or bending them, but regulators who feel under pressure from politicians are likely to forbear at other times too. And the expectation of forbearance may be even more damaging. Regulatory forbearance creates risk through adding uncertainty about outcomes; it also distorts incentives; and it confuses market signals since prices reflect the probability of a bailout as well as financial health.

${ }^{30}$ Even when firms report asset "fair values" in footnotes, it is not clear how meaningful those numbers are, and there are clearly major differences between firms. Because firms with insured liabilities don't face market pressure from creditors to prove that their assets are worth what they claim, there is less incentive to be transparent. And much less about the value of the firm's assets can be inferred from debt prices, if the firm is potentially eligible for a bailout.

${ }^{31}$ While there may be an asymmetric information problem deterring asset sales, sometimes even because the potential buyer (e.g. a hedge fund, investment bank, or private equity firm) is likely to know more than the commercial bank seller, there is much more likely to be a problem with voluntary equity sales. The reason is that equity involves a pooled claim against all the assets of the firm, including intangibles, and management should have an informational advantage in estimating this value even if it has no advantage in estimating the value of any individual tangible asset offered for sale.

${ }^{32}$ For example, say management knows the true value of shares but investors only know they are worth between 70 and 130, with an expectation (and so current stock price) of 100. Management acts in the shareholders' best interest. Then equity can be sold without any adverse selection if it is needed to finance a project commonly known to be worth 130 percent of cost, since in that case shareholders will gain regardless of the true value of the current shares. If on the other hand the value of the firm declines to the range of 0 to 60 with an expectation (and stock price) of 30 , shares will not be sold to finance a new project, due to "unraveling", unless returns from the project are at least twice the cost.

${ }^{33}$ Draft legislation introduced by the U.K. government in October 2012 would force banks to give retail depositors preference over bondholders and other creditors if a bank fails (Goff, 2012). In a U.S. bank insolvency, domestic deposits (both insured and uninsured) are already senior to general creditors. Insured depositors provide no market discipline because of their immunity from losses. 
A clear example of regulatory forbearance was the pressure placed on the US Financial Accounting Standards Board to change its treatment of losses stemming from other than temporary impairment of asset values. Because of the Federal Deposit Insurance Corporation Improvement Act (FDICIA), enacted in 1991 in response to the savings and loan crisis, regulatory accounting was required to be at least as tough as financial accounting. So in 2009 Congress pressured the FASB to make financial accounting rules more lenient in the ways necessary to make regulatory accounting more lenient. ${ }^{34}$ Another example is when regulators bent the rules to allow IndyMac to make retroactive transfers to retain "well capitalized" status and access to brokered deposits two months before it collapsed with a loss of 42 percent (\$13 billion) of assets in the U.S.'s largest bank failure in 2009. ${ }^{35}$

The U.S. is hardly unique in this way: consider the creation of Japanese "zombie banks", and the European stress tests. The perceived need to bail out the banks can affect more than just accounting and the guarantee of banks' senior debt; for example, Europe's decision to postpone recognizing Greece's insolvency may have been partly related to the regulatory impact of banks' being forced to recognize the fair value of their risky sovereign loans.

\section{d. Inefficient Allocation of Risk to Taxpayers}

Allowing investors to transfer risk to taxpayers through the regulatory capital and bank insurance system is hugely inefficient because governments are much poorer risk-bearers than private investors in the capital markets. First, the stakeholders in the government are not as wealthy, on a weighted average basis, as the stakeholders in the capital markets. ${ }^{36}$ While one can claim that people with no financial wealth might optimally bear at least some financial market risk, this argument depends on financial market risk not being highly correlated with the risks people with no financial wealth already bear. ${ }^{37}$ It is clear that even people who do not own any stock already suffer financial hardship during a banking crisis

\footnotetext{
${ }^{34}$ The subcommittee Chairman argued it was outrageously tough, for example, that the Federal Home Loan Bank of Atlanta had to recognize a loss of $\$ 87$ million, or less than 1/30 of the bank's own estimate of its fair value losses of $\$ 2.7$ billion on securities; see U.S. House of Representatives (2009). Congress is not solely to blame for this forbearance. The Office of Thrift Supervision, in writing the FDICIA regulations, decided, in contradiction with the plain language of the statute, to exclude from the calculation of regulatory capital any fair value losses due on "other than temporarily impaired" (OTTI) assets. See Kroeker (2009).

${ }^{35}$ By allowing the parent company to book a May 9, 2009 transfer from the parent to the banking subsidiary on March 31, IndyMac was able to retain the "well capitalized" status necessary to be allowed to pay more than 75 basis points above the "prevailing market rate" to attract brokered insured deposits; see Andrews (2008). For example, IndyMac offered $4.10 \%$ on six month insured CDs at the time of its demise in July 2008 vs. a national average rate of $3.10 \%$. IndyMac had $\$ 6.8$ billion in such funding (22 percent of liabilities) when it collapsed.

${ }^{36}$ If losses were paid for using the 2012 "French model" of no spending cuts and a progressive wealth tax this argument would not hold, but even in France there is no prospect of this approach covering more than a small fraction of losses.

${ }^{37}$ Of course governments already are exposed to enormous financial market risk through myriad guarantee programs including the residual responsibility for any shortfalls in insured defined benefit pension funds.
} 
because of the decline in the economy, both in terms of short-run and long-run income. ${ }^{38}$ That decline, more than the direct costs of a bailout, stresses government finances. ${ }^{39}$

A second reason why governments are poor risk bearers is that they are generally poor at saving or smoothing, because when more income and borrowing capacity comes available in boom times there is a strong political temptation to spend it. ${ }^{40}$ For example, the U.S. temporarily ran a budget surplus in 2000-2001, reducing debt as a fraction of GDP, before returning to deficits by a combination of large spending increases and tax cuts, even while its economy was still doing well. ${ }^{41}$ The recent U.K. experience is similar. Mexico's sovereign debt crisis in 1982 came about after a decade in which oil export income rose from almost nothing to $\$ 20$ billion per year, but sovereign debt rose from $\$ 5$ billion to $\$ 50$ billion. ${ }^{42}$ Certainly looking at the recent financial crisis, it would be difficult to argue that government finances have held up nearly as well as those of financial market investors--one of the main concerns of financial markets now is that government balance sheets are so stressed. Ireland's depression provides an extreme example of the cost of transferring tail risk to the taxpayer.

\section{A Market-Based Bank Capital System}

\section{a. Objectives}

Our system is designed to meet four objectives:

- First, "property rights" in losses must be well defined, and credibly allocated to the private sector. Once these losses are allocated, private investors can re-allocate them amongst themselves, if doing so creates value.

\footnotetext{
${ }^{38}$ For example, Oyer (2008) argues convincingly that career incomes are affected by whether a young person starts his or her career during a boom or a bust.

${ }^{39}$ See e.g. Carmen M. Reinhart and Kenneth S. Rogoff (2009), "This Time is Different", Princeton University Press, e.g. p. xxxvii. "On average, government debt rises by 86 percent during the three years following a banking crisis. These indirect fiscal consequences are thus an order of magnitude larger than the usual cost of bank bailouts". Also see Reinhart and Rogoff (2011). In the U.S. public debt securities held by private investors rose from $\$ 3,635$ billion at the end of fiscal 2007 to $\$ 7,676$ billion at the end of fiscal 2010. See Table B-88 in the Economic Report of the President.

${ }^{40}$ See for example, Tornell and Velasco (1992) and Tornell and Lane (1999).

${ }^{41}$ The U.S. went from a primary surplus of 4.8 percent in fiscal 2000 to a primary deficit of 2.0 percent in 2003.

${ }^{42}$ A classic example involves state pension funds in the U.S. These funds have earned approximately their projected rates of return over the past 30 years. However, because of a tendency to dissipate surpluses when returns are good and to defer increasing plan contributions when times are bad, these plans are now deeply in deficit. That is, they are deeply in deficit based on their own discount rate assumptions. This is separate from the point that a 7 to 8 percent discount rate, while appropriate 20 years ago, is ridiculously high when long-term treasury rates are 3 percent. For underfunded private pensions, governed by Pension Benefit Guaranty Corporation regulations, Congress "takes care" of problems like this by regularly relaxing funding requirements. Starting in 2012, for example, firms are to be allowed to average interest rates over the previous 25 years in computing their discount rate for funding purposes.
} 
- Second, the system must be robust to error, without permitting the sudden collapse of any SIFI. Risks must be taken, and SIFIs will have losses and may eventually fail. But even when large losses occur, SIFIs must still be able to operate efficiently without either a sudden failure or a bailout. ${ }^{43}$

- Third, the system should be counter-cyclical, where regulation dampens or at least does not intensify business cycles. It should be at least as cheap, if not cheaper, for banks to invest in bad times as in good times.

- Fourth, as much as possible, the capital requirements for the same portfolio should be essentially the same regardless of the form of the asset holder. Efficient organizational forms will be chosen only if the regulatory system does not bias such choices.

To achieve these goals, we rely on markets to determine banks' capital requirements, much as they determine the capital requirements of banks' customers. Most important, using market information yields simple, clear rules. Well-defined, bright-line, rules prevent regulators exercising (non-transparent) forbearance; simple rules are hard to game; and rules that are independent of organizational form avoid regulatory arbitrage.

Because our system avoids government subsidies, the market signals it generates are not obscured by the prospect of bailout, and so are more meaningful. However, while market information should not be ignored, there will sometimes be large disagreements between markets and executives or regulators, ${ }^{44}$ and our system does not depend upon markets being right. Crucially, our market-based system protects taxpayers regardless of whether markets are right or wrong. By contrast, current regulatory systems leave taxpayers vulnerable to the possibility that the markets are right when the markets are more bearish than the regulators. The trick, of course, is to find a way to use the markets given the constraint that certain institutions are regarded as too important to suddenly fail.

In the next section we describe how we do this by implementing the two basic principles we set out in the Introduction --- that any SIFI that cannot be quickly wound down must limit the recourse of nonguaranteed creditors to assets posted as collateral plus equity plus unsecured debt that can itself be converted into equity, and that any debt that is to be guaranteed by the government, such as stable value retail deposit accounts, must be backed by government-guaranteed securities --- for five types of bank obligations: unsecured debt; secured debt and derivatives; deposits; lines of credit; and wages,

\footnotetext{
${ }^{43}$ Academic economists can debate the wisdom of bailing out SIFls. The fact is that governments now do so, and markets behave in the expectation of this. A plan that assumes the sudden collapse of a SIFI may be permitted is not a credible plan. Section $6 \mathrm{~d}$ discusses why "big bang" bail-in/living-will proposals may not suffice.

${ }^{44}$ For example, AIG'S CEO, Martin Sullivan, complained of having to write down assets by $\$ 11.1$ billion at the end of 2007 when the firm's model "stress test worst-case scenario" was a loss of $\$ 900$ million. See McSheehy and Son (2008). For criticism of mark-to-market or fair value accounting see American Bankers Association, "Fair Value and Mark to Market Accounting". Most Congressmen attending the hearings on fair value accounting ( U.S. House of Representatives (2009)) bitterly attacked "fair value", which is something like estimated mark-to-market with "fire sale" transactions ignored. Rep. Alan Grayson (pp. 53-54) is a humorous exception. On January 12, 2009, the FASB issued an exposure draft of FSP No. EITF 99-20-1, "Amendments to the Impairment and Interest Income Measurement Guidance of EITF Issue No. 99-20" removing the requirement to use "market participant" assumptions for purposes of testing for "other than temporarily impaired" loss write-downs.
} 
trade credits, and legal claims. In terms of the academic literature, we are closest in spirit to Robert Merton and Zvi Bodie (1993) and Merton Miller (1995). ${ }^{45}$

We then address issues such as the potential for downward spirals, which is a flaw in some contingent capital plans but not ours, and how our plan helps resolve both solvency and liquidity issues, before contrasting our plan with others, and discussing transition issues. In particular, a realistic medium-term goal might be to implement ERNs and "ring-fence" deposits, but leave until later the requirement that government-guaranteed-debt be fully backed by government-guaranteed securities.

\section{b. Unsecured Debt}

All unsecured debt would be in the form of securities we call "equity recourse notes" (ERNs). Specifically ERNs would be convertible, payment by payment, into shares of stock at a minimum percentage (say 25 percent) of the share price on the day the ERNs were issued. So, for example, if an ERNholder were due a payment of $\$ 1000$ but the bank's common stock had fallen from $\$ 100$ when the ERN was issued to below $\$ 25$ on the day the price for conversion was determined then the ERNholder would receive 40 shares of stock in lieu of cash. The issuer would not have the option to pay in cash when the stock price was below the trigger-price. ${ }^{46}$

This proposal differs from existing contingent convertible "coco" bonds in four important ways. ${ }^{47}$

- First, conversion is triggered by market values, not regulatory value. The typical (non-academic) coco proposal involves the conversion of debt to equity when a regulatory capital level is breached, because it is designed to assure that the bank will have adequate regulatory equity. Because regulatory equity can be manipulated it is possible that a bank could fail before a coco converts, and pressure on the regulators for regulatory forbearance ("a conversion will destroy confidence in the banking system", "now is the worst possible time for this to happen") can make conversion a political rather than an economic event. Academic proposals, tend to base conversion on aggregate values rather than share prices. ${ }^{48}$

\footnotetext{
${ }^{45}$ See also Black, Miller, and Posner (1978) for an earlier article which shared some of the same sentiments.

${ }^{46}$ The reason is that the option of paying in cash when the stock price is low might make managers feel a de facto obligation to do this to signal strength. (Regulators would also retain authority over stock buybacks and dividends to prevent pressure on firms to announce repurchase plans to undo conversions.) If the stock were selling above 25 the bank would have the option of paying in stock valued at 25. If a payment were due to be made in stock a bondholder would have the option of deferring payment for six months at a time at zero interest in the hopes of receiving cash later. Of course, we would expect these alternatives to be rarely used.

${ }^{47}$ Two discussions of cocos by regulators are Basel Committee on Banking Supervision (2011) and Financial Oversight Stability Council (2012).

${ }^{48}$ Chen et al. (2013) is a recent paper that briefly discusses the growing co-co literature starting with Flannery (2005). Conversion based on aggregate market values would be more complicated for investors to hedge than conversion based on stock price. A requirement for a minimum ratio of market value of equity to unsecured debt would greatly complicate our goal of allowing banks to issue more senior securities when asset values fell. In our system, firms would still be able to negotiate covenants with creditors that could be based on aggregate market values or even Basel-like rules. For example, new junior ERNs (issued in good times) might be made more attractive to investors through constraints on
} 
- Second, ERN conversion prices are set on the date securities are issued, not on the market price near the conversion date. Crucially, securities that convert on a formula based on the conversion date market price can contribute to a "downward spiral"; by contrast, our securities should stabilize equity prices, as we discuss later. Each coupon bundles a riskless bond and a short of a simple (European) equity put option. Because the conditions for a conversion are so well-defined and transparent, ERN risk is straightforward to hedge.

- Third, because our system effectively counts ERNs as equity from when they are issued, there is no regulatory reason to convert an entire bond at one time, rather than just a single payment. In our system, conversion of an individual (interest or principal) payment is determined by whether the stock price is above or below the conversion price on the determination date. In typical market-price coco schemes the entire bond issue converts when a stock price barrier is breached, even if no payments are due at the time. ${ }^{49}$ As we will argue later, this difference is important for mitigating or eliminating perverse incentives (e.g., bondholders rooting for the stock to go down to trigger conversion) and closely related problems of multiple equilibria. ${ }^{50}$

- Fourth, we envision ERNs replacing all unsecured long-term debt, not just a small amount. So while co-cos are junior capital that banks will find hard to issue as their finances worsen, ERNs issued in times of distress will be senior securities.

The last point-that new ERNs issued in bad times will be senior securities--is crucial. The reason is that the conversion price of ERNs is proportional to the share price on the issue date. The more the stock price falls, the more senior are new ERNs to old. If new ERNs are issued when the share price is half as high as when old ERNs were issued, then the holders of the new security lose nothing until the older bondholders have lost half their investment, after which (if and when both issues are converted to equity) they share losses proportionately. The seniority creates a "reverse debt overhang", and also makes it possible to raise capital without either creating an overall more risky capital structure by selling conventional debt or sending an adverse signal by selling equity.

So ERNs reduce cycles in four inter-connected ways:

- Debt repayments are automatically converted to equity as asset values fall, conserving funds in times of stress.

- Eliminating the concept of regulatory capital and the role of government insurance reduces "debt overhang". ERNs then create the reverse effect by permitting the issuance, in bad times, of claims that are senior to existing unsecured debt.

- Because issuing ERNs is relatively cheap in bad times, doing so can send a better signal about the bank's prospects (involve less adverse selection) than selling even moderately informationintensive assets, and much less than selling stock.

dividends and share repurchases. But as taxpayers are protected in other ways these terms would not be determined by regulators.

${ }^{49}$ Glasserman and Nouri (2012) is an example of a proposal which converts bonds gradually, bailing in whatever amount is needed to remedy a regulatory capital shortfall.

${ }^{50}$ It also means that investors who are not allowed to hold equity will only have to sell the proceeds of the current payment, rather than the entire bond, when a conversion occurs. 
- Conversely, ERNs will be harder for a bank to issue than conventional bonds when its stock has risen: the bonds will be junior rather than equal to other unsecured debt. So ERNs also slow "upward spirals".

While ERNs counteract the pro- cyclicality problem that is inherent to conventional debt by giving some priority to new debt issued after a stock price decline, bonds issued in good times take on more equitylike characteristics (become more junior) as the stock price falls. New debt can be raised in bad times at prices above the average debt price and no new equity has to be issued to fund new investment, so the marginal cost of funds in bad times is below the average cost, implying a counter-cyclical investment incentive. But the ability to issue subsidized debt in bad times comes from what is effectively insurance sold by bondholders who supplied money in better times; these creditors will charge for the risk that they will bear, and if investors regard management as making dissipative investments they will be less willing to make new loans despite the current seniority.

We would insist on substantial significant average minimum maturity, for any SIFI's ERNs. There are two reasons for this. First, we want to clearly communicate that ERN holders will take losses in bad states of the world. If ERNs were short-term, there would have to be a significant chance of a short-term share price collapse for them to bear any significant risk. Second, banks will always have a signaling incentive to issue the shortest allowable ERNs--we want to coordinate on an equilibrium where they can raise longer-term capital without any negative signaling implications.

We would also constrain the term structure of a SIFI's ERNs so that, with de minimis exceptions, not more than some fraction (say $1 / 3$ or $1 / 4$ ) of debt scheduled to be outstanding at any time could be due within the following year. ${ }^{51}$ The reason for this is to allow new ERNs to be issued with a maturity structure that matches the maturity structure of remaining old debt, so newly issued bonds will not be de facto junior to outstanding old bonds because of a longer duration.

We suggest a 25 percent minimum conversion price as a percentage that will make a conversion unlikely but not implausible given current capital structures. This rate would provide a clear signal that things have changed from the current system. An advantage of a higher conversion price is that it will allow the mechanism to be tested and demonstrated before a new crisis. The away-from-zero conversion price gives us a market-based "Prompt Corrective Action" approach to troubled banks that allows new capital to be raised passively.

A gradual conversion reduces incentives for manipulation by managers and market participants, and for forbearance by regulators, as we discuss below. How effective the conversion mechanism would be at providing a gentle bail-in will depend on the ratio of equity to ERNs in the bank's initial capital structure. The very simple simulations described in section $5 b$ assume ratios of ERNs per share similar to those for unsecured (non-deposit) debt outstanding for major banks prior to the financial crisis. But because the total value of required unsecured capital will be determined by secured lenders, and all ERNs will be

\footnotetext{
${ }^{51}$ For example, we might require that if a bank issued $\mathrm{N}$ bonds at time 0 (and no others), then at most $\mathrm{N}\left(1-(2 / 3)^{t}\right)$ bonds could be scheduled for repayment through year $\mathrm{t}$. A de minimus exception could be made to allow all remaining bonds from an issuance to be paid back after say 10-12 years. Government securities could be counted as the negative of ERNs due at time 0 , allowing a well-capitalized bank with excess reserves to issue a greater proportion of debt with shorter maturities. Of course a repayment constraint of this sort automatically sets a minimum duration for ERNs--as we advocated in the previous paragraph.
} 
convertible, the solvency of the firm will remain absolute, independent of the ERN/equity breakdown. So our instinct is to largely leave the choice of the ERN/equity ratio, which will go up and down as stock prices fall and conversions kick in, largely to the market. We would, however, limit the ability of banks to constrain their future issuance of ERNs through debt covenants, to ensure that any distressed firm can always raise new senior funds; ${ }^{52}$ and we would also give regulators the discretion to limit stock dividends and buybacks, and to require additional equity if they believe conditions warrant. ${ }^{53}$

As we show in section $5 \mathrm{~b}$ a 25 percent rate would have meant that relatively well capitalized banks would have had few if any conversions in 2008-9, assuming the same share price history. Weaker banks would have been infused with large amounts of new equity, moderating declines in share price and likely leading to less dilution than actually occurred in the worst cases. We note in section $5 \mathrm{~b}$ that a bank like Citigroup might have had similar aggregate dilution with a conversion rate of 10 percent as with 25 percent, but in the 10 percent case almost all the conversions would have occurred over a much shorter period.

With a 25 percent conversion rate a bank would only have to raise its equity by less than a third to make its unsecured debt as unlikely to suffer any losses as under the current system without bailouts (see footnote 87). Note that regardless of the conversion rate, new bonds issued with the same conversion rate and repayment dates when the stock has fallen $\mathrm{x} \%$ will be immune from losses on all repayments unless old bondholders have lost $\mathrm{x} \%$ of their promised repayment, for all $\mathrm{x} .{ }^{54}$

Whatever the conversion rate and repayment rate (duration), the combination of 100 percent reserve banking for guaranteed accounts and ERNs will require banks to compensate for shortfalls in unsecured capital through some combination of asset sales and raising additional unsecured capital, and will make the raising of unsecured capital easier.

Investors will still be able to acquire short-term bank debt, even when all unsecured debt is issued as ERNs or equity. First, it would still be possible to acquire short-term secured bank debt, as we discuss in section 3c below. Second, trusts could purchase ERNs and securitize and tranche them, as is currently done with mortgage debt and municipal bond debt. The trust may issue senior short-term debt that rolls over. While some might describe such ERN trusts as "shadow banks", regulating them would be much more like regulating a mutual fund than a commercial bank, because they would hold only easily-valued assets. They would be much simpler than mortgage trusts, where the value of securities can be affected

\footnotetext{
${ }^{52}$ Banks could write debt covenants that limited dividends and share buybacks. They could also commit that if the ratio of equity to ERNs fell below a specified level, that for every one percent increase in the face value of ERNs outstanding, the firm would issue at least $z$ percent additional shares. We would insist that $z \leq 1$ to ensure firms in bad times could issue bundles of equity and debt that were senior on average to old securities (because the new debt would be senior to old), and so (at least somewhat) countercyclical. Regulators could also adopt such an equity issuance requirement.

${ }^{53}$ We would, for example, wish to avoid a troubled firm raising the price of its stock (and hurting existing ERNholders) by selling assets and using the proceeds to buy back most of its stock (though private debt covenants would probably take care of this issue).

${ }^{54}$ It would be possible to make ERNs even more countercyclical by making the minimum conversion rate tied to a national variable such as the unemployment rate as well as to the stock price at issuance (e.g. a conversion rate of 40 percent less twice the unemployment rate). However, it would then be necessary to assure ERN buyers that the formula will not be changed to give more seniority to future issues, and that might be less credible than simply committing to a minimum conversion rate.
} 
by servicers' decisions about modification and foreclosure. Investors in the securities sold by ERN trusts would have to be taught that even senior short-term claims eligible to be held in prime money market funds would not be riskless. We would achieve this partly through our money fund reforms, which would anyway make these funds much safer (see section $3 \mathrm{~d}$ ). ${ }^{55}$

The corporate finance literature (e.g., Hart and Moore (1995)) argues that an important role for conventional debt is to make it more difficult for firms to raise more funds for bad projects after they have suffered losses, creating a trade-off with debt-overhang's constriction on fund-raising for good projects. In principle, ERNs reduce the ability to commit to a structure that limits the ability to raise funds when performance is poor. Furthermore, when equity increases in value, ERNs increase the cost of unsecured debt because newly issued bonds are then junior to old ones. ${ }^{56}$ So ERNs' counter-cyclicality can also slow the flow of funds from firms that have performed poorly to those that have performed well. However, relative to a world where either bank creditors are provided with subsidized insurance or unsubsidized banks are required to issue much more equity than the market would demand, ERNs reduce the overall potential for asset dissipation by poorly performing firms, and so improve efficiency. We discuss this further in section $4 d$.

\section{c. Secured Debt and Derivatives}

In the current system, secured debt is typically backed by collateral worth more than the amount of the loan, plus an unsecured claim against the borrower for any shortfall. The better funded a firm is, the smaller the haircut it is likely to have to pay on a secured loan, but all else equal an insured institution that would be bailed out if it failed would have to put up less collateral. That is, any implicit or explicit government backing of a financial institution will distort the terms on which it can borrow in the secured market.

We wish to roughly duplicate current secured debt, while leaving all risk in the private sector. So we want the bank to be able to offer its creditors recourse to its unsecured capital, but without risking collapse. We therefore give borrowers the option of repaying shortfalls in the value of collateral either in cash, or in ERNs, issued on the date the loan is terminated, using the minimum allowable conversion rate (e.g. 25 percent) and the greater of the current share price and the average closing price over the term of the loan up to 90 days, and paying the same interest as on three-year Treasury debt. ${ }^{57}$ This would imply the ERNs would be worth a small discount to par. ${ }^{58}$ (However, we expect that collateral

\footnotetext{
${ }^{55}$ Even if the message were not adequately communicated, and money fund losses require government intervention the record of money funds suggest that taxpayers' exposure would be small relative to their current exposure to conventional commercial bank default (even if our reforms were not made).

${ }^{56}$ Raising moderate amounts of capital would generally remain easier in good times than bad, because the increase in asset values that raises the value of equity would probably allow the firm to raise some additional funds as secured debt without it needing to sell more ERNs or equity.

${ }^{57}$ For a country whose sovereign debt is riskier than its bank debt, this rule would have to be modified.

${ }^{58}$ We do this for several reasons: first, we want no adverse signaling effect from the borrower repaying in ERNs. Second, by giving a secured creditor slightly too little on any unsecured part of its loan, we remove any incentive to create sham secured debt, e.g., where trivial collateral is put up for a large loan, with the intent that the borrower will "default" and pay the lender ERNs which were higher priority or otherwise superior to those which could be issued as ordinary unsecured debt. Finally, we want lenders to have an incentive to get the best possible price for seized assets. (By contrast, the current system gives lenders little incentive to get a good price for foreclosed assets.)
} 
would normally be adequate, and risk-wary lenders will increase collateral requirements if they are worried about receiving ERNs.) $)^{59}$

We would also regulate the assets borrowers could use for collateral. All assets held for trading or portfolio investment could be used, but any assets central to the continuation of the bank (or other SIFI), such as proprietary software programs and some intangible assets, would be ineligible for use.

Note that, just as in the private sector now, for example, when banks lend to borrowers, the "capital requirement" (that is, the value of the asset less the amount that the bank is able to borrow) that the bank will face will depend on not only on the asset's price, but also its volatility and liquidity, the bank's strength and reputation, the contractual terms for replenishing collateral, and so on. In our system, the regulator does not need to make any judgment about any of these things--it simply requires the bank to finance with ERNs and equity any amount that cannot be acquired through collateralized borrowing. If a bank can borrow 60 against a bond or pool of loans that has a regulatory value $p$, then we know the market-based regulatory capital requirement is $p$-60, regardless of whether $p$ is 40 or 100 , and regardless of all the other factors that determine the lender's haircut.

Some secured creditors might demand higher haircuts because of the risk of being repaid for any shortfall in ERNs, but for many creditors this risk may be outweighed by the assurance that their funds will not be tied up in a bankruptcy procedure--a creditor would not have to worry about whether it was lending to a firm in distress, or even to a firm that others might think is in distress. (This also eliminates an important bank run dynamic, as we note in section $4 \mathrm{~b}$.)

Derivatives can be treated just like secured debt, with the debtor having the option at termination to pay any shortfall beyond posted collateral in ERNs. In addition, we could make further modifications to the treatment of derivatives to address current concerns about derivatives termination-see Appendix 3.

\section{d. Deposits and Money Market Funds}

We would apply the same rules to funds held in money market funds and in banks. In effect, bank deposits would be issued by money market funds that were captive subsidiaries of the banks. "Government" funds would take the role of insured deposits --- a change similar to moving to the $100 \%$ reserve or narrow banking requirements advocated by many distinguished economists such as Fisher (1935), Friedman (1959), Tobin $(1985,1987)$, and Merton and Bodie (1993). They would be stable value accounts, with issuers required to either hold a small amount of additional collateral or buy cheap insurance from the government to guarantee against the (small) interest rate risk in the value of the

\footnotetext{
${ }^{59}$ Theoretically a sudden large collapse in the value of secured assets could make a bank worth less than outstanding secured debt and, depending on the conversion rate for new ERNs, old ERNs and equity could become almost worthless, but even in this improbable case there would not be a bankruptcy. For example, say the collapse left the bank owing some secured creditors $\$ 20$ billion, while the bank's other assets (net of secured debt) were worth just $\$ 10$ billion. These secured creditors would be given ERNs, and even if the share price used in pricing the ERNs approached zero (which would wipe out old ERNholders and equity and give these creditors close to all the remaining \$10 billion in value), the firm would continue the next day with unsecured capital worth $\$ 10$ billion.
} 
underlying portfolio. (The insurance would not be subsidised; it would be cheap because risks would be low). ${ }^{60}$

In theory, banks create liquidity and transfer risk by issuing short-term deposits and investing in longterm loans with fixed collateral and limited recourse. In recent practice, however, undercapitalized banks in effect provide government debt to depositors, and the banks in turn acquire this debt from the government in return for unsecured bank debt and mispriced deposit insurance. In our system savers who wanted short-term government-backed claims could still get them, without the government providing a large subsidy to the banks. Unsecured medium and long-term ERNs issued by wellcapitalized financial firms, securitized and tranched, would allow for private maturity transformation and risk transfer.

Banks could also offer funds backed by non-government securities. These "prime" funds would be treated like other mutual funds with floating asset values. ${ }^{61}$ Of course, if banks kept portfolios that were short term and low risk, asset value fluctuations would be very small. ${ }^{62}$

Making net asset values reflect changes in value, as with other mutual funds, removes the incentive to move assets out of funds with market net asset values below $\$ 1.00$ that caused the run on the Reserve Fund money market fund. ${ }^{63}$ Furthermore, since it is likely that government-guaranteed deposit accounts would offer a lower interest rate relative to other accounts in our system, the incentive to run to such accounts (which paid more than money funds in the fall of 2008) would also be reduced. ${ }^{64}$

${ }^{60}$ For 2000 to 2010 U.S. government money market funds fluctuated in market value between 99.98 percent and 100.15 percent of par. See Investment Company Institute (2011), Figure 14.

${ }^{61}$ That is, in the U.S. we would abolish the 1983 SEC Rule 2a-7 which allows qualifying funds to both use amortized cost accounting for determining asset value (i.e., ignore changes in asset value due to changes in interest rates), and then use "penny rounding" to avoid "breaking the buck (i.e., round up net asset values as low as $\$ .995$ to $\$ 1.00$ ); see Cook and Duffield (1998) for a description of the history of money market fund rules. The SEC tightened up money market liquidity, credit quality, and portfolio maturity rules in 2010. See SEC (2010) for a summary. Our proposals here are close to the 2012 SEC proposals for reforming money market funds. Mishkin (1999) discusses having banks offer both guaranteed and non-guaranteed accounts.

${ }^{62}$ One significant incentive for financial officers to move funds from "prime" money funds to government funds during the crisis was that prime funds were worth about 99.8 cents per share on average while government funds were worth about 100.1 cents. See Investment Company Institute (2011).

${ }^{63}$ The run on the Reserve Fund money market fund was sparked by a loss of about one percent of the firm's assets. Because the fund was continuing to redeem claims at $\$ 1.00$ when they were worth $\$ .99$, investors who would have sat tight were shares marked to market or below were forced to request withdrawals to avoid being stuck with a disproportionate share of the losses. Requests for withdrawals representing $2 / 3$ of all fund assets were made between Monday morning and 3 p.m. Tuesday when the fund froze accounts. Had all these transactions been processed, remaining investors would have been down to 97 cents. The Reserve Fund fiasco made the alternative of explicitly insured bank deposits more attractive, even as banks were in financial distress

${ }^{64}$ That said, we note that the money market fund problem is small relative to the commercial banking problem. For example, the U.S. government, which lost about \$13 billion on the failure of mid-sized IndyMac, has never lost money on a money market fund, and private investors have lost a total of about 
We think most investors would quickly accept a move to regularly revaluing assets to reflect small changes in value: if a fund held a portfolio with an average 45 day maturity short-term rates would have to spike by 80 basis points overnight to cause a 0.1 percent loss in net asset value (assuming no defaults); most losses would clearly be considerably less, and would tend to be balanced by small income gains in the following weeks as the assets ran to maturity ${ }^{65}$ In any event, allowing uninsured bank accounts to take small losses from time to time will help persuade uninsured depositors that they will not be bailed out.

Thus a bank in Spain, say, might offer accounts backed by Spanish government debt, guaranteed by the Spanish government. It would be required to hold 100 percent collateral against such accounts, but it could also offer additional backing through more collateral or by backing the accounts with unsecured promises convertible into ERNs if the Spanish government defaulted. Such a bank might also issue accounts that represented an "index" of European government debt, which would effectively be a money market mutual fund. So for example, if not backed by additional collateral a depositor in such an account might lose 0.2 percent if Cypriot debt suddenly became worthless, but would not be able to force the bank into default.

We discuss in section 7 the possibility of a transitional phase in which deposits are held in a ring-fenced bank.

\section{e. Lines of Credit}

A major problem during the early days of the current crisis involved off-balance sheet financing. A bank might provide a 364 day line of credit to an off-balance-sheet entity which would then lend long and use the credit line to enable it to borrow short. One result was that as the credit crisis began bank balance sheets actually expanded as these off-balance sheet risks came on balance sheet, even though in reality banks were tightening their lending policies.

As of December 31, 2012 U.S. banks had outstanding $\$ 5.846$ trillion in unused loan commitments. Some lines of credit to consumers may be cancellable with no penalty to the financial institution and so could be ended with no legal liability if the bank were in financial difficulty. Other lines, for example a commitment to backstop commercial paper that a customer might not be able to roll over, may create potentially expensive obligations, as occurred with "structured investment vehicles" (SIVs) and "conduits" in 2007-8. ${ }^{66}$

$\$ 600$ million (almost all due to Reserve Fund) over 40 years. There have been perhaps 21 other cases where sponsors have subsidized funds to avoid "breaking the buck"; see Brady et al. (2012). While we advocate changes in money market fund rules, we are concerned that if they are not accompanied by changes in the rules for more risky commercial banks, the transfer of deposits from money market funds to commercial banks will increase taxpayer risk.

${ }^{65}$ Such small losses will probably be even less problematic when all such funds show tiny market moves. By contrast in the current environment in which almost no money fund ever loses money, managers are scared of being in an outlier fund that loses one percent. Some 90 percent of the withdrawals from prime money funds after Lehman were from "institutional" funds.

${ }^{66}$ Acharya et al. (2010) describe how SIVs and conduits worked, and how they were structured to avoid capital charges on hundreds of billions of dollars in assets. 
We would treat these lines of credit as unsecured debt of the bank. Therefore, if the guarantee to provide credit were unconditional the bank would have to hold cash or government securities for the full amount of the commitment. If, however, the bank could cancel the contract in return for paying some penalty fee, even after the borrower asked for its loan, then only the prospective penalty would count as a liability. If the penalty fee were payable (at the option of the bank) in bank stock or ERNs, on terms similar to those discussed for shortfalls in the value of collateral on secured debt, or if the contract could be cancelled without penalty, there would be no capital charge.

Note that this simple system is possible because we are designing a system that is focused on ensuring that the bank does not fail because of a contract, and so we are largely concerned about what the contract requires in tail states. If, conditional on a tail event occurring, the bank can settle up merely with equity dilution, then the institution's other creditors are protected, as is the government insurer.

\section{f. Wages, Trade Credits, and Legal Claims}

We would treat other claims against the bank as requiring either government-security backing or ERN backing, depending on whether the claims were regarded as capable of bearing loss. For example, if a bank lost a large lawsuit (the law could mandate that) creditors could be paid in ERNs, so protecting against bankruptcy. If a bank promised bonuses to employees it could either put away cash towards the bonuses or retain the option to pay in ERNs, with the maximum amount of ERNs limited by the amount of cash promised.

\section{Downward Spirals, Liquidity, and the Ability to Fail}

\section{a. Stock-Price Downward Spirals}

A common concern is that contingent convertible securities can lead to "downward spirals". The most important reasons for the historically poor-and sometimes disastrous--performance of securities that convert on the basis of market price are significant design flaws which do not exist in our plan.

Most important, we fix the price of potential conversion(s) on the date the security is issued so that the number of shares that ERNholders receive in any conversion is computed using a share price above the price at the time of conversion (the opposite of "death-spiral" bonds). Expressed differently, a bank effectively buys a series of put options against its own stock every time it sells an ERN. So current shareholders share losses with bondholders if equity prices get too low, making the equity less risky.

We also fix the dates of potential conversions, and limit them to one payment at a time.

To elaborate:

(i) How ERNs prevent stock-price downward spirals in conventional finance models

Historically, the worst spirals occurred when conversion gave creditors more than a dollar's worth of stock for every dollar's face value of debt. Consider the following example of a "death spiral" bond, based on some of the securities issued at the turn of the century. Creditors have a bond due to be paid 90. There is one share of stock outstanding. If the value of the stock is $p<25$ the creditors are due to be paid 100/p shares of stock instead of cash; that is, they are to receive stock worth 100 at current market prices in return for their claim of 90 . If the value of the stock is greater than 25 shareholders are paid in cash. Say the value of the firm is just over 115 on the day the bond payment is determined. Then the 
bonds are paid 90 and the stock is worth (just over) 25. But if the value of the firm is just under 115 , the share price must fall discontinuously to (just under) 15 , since the bonds will receive 100 in stock.

By contrast, in our plan bondholders receive stock with a market value less than the debt's par value, which increases the price of the stock, that is, stabilizes prices. Because ERN conversions transfer wealth to the shareholders, they reduce share price volatility relative to conventional debt, as well as relative to "death spiral bonds" (even those that convert at the current market price), and relative to put options against the firm's own stock (as some firms, such as Maytag, have sold to their regret).

To see how ERNs eliminate downward spiral problems, consider a capital structure in which $S$ is the value of shares outstanding, $B$ is the face value of debt, all due imminently, and $V$ is the total value of the firm. Then if the elasticity of share price with respect to firm value, $e,{ }^{67}$ increases as the value, $\mathrm{V}$, falls, the firm is sensitive to downward-spiral problems. We contrast four capital structures:

Conventional debt. $S=\max (0, V-B)$, so $e=V /(V-B)$ for all $\mathrm{S}>0$. For example, if $B=80$ and $V=160$, a 1 percent decrease in $V$ decreases share value by 2 percent, because of 2:1 leverage, but if $V$ falls to 100 leverage becomes 5:1 and a 1 percent decrease in $V$ reduces share value by 5 percent.

"Death-spiral bonds". We define a death-spiral bond as a security that promises to pay bondholders a cash amount of $B$ if $V>V^{*}$, and shares with a market value of $D(V)$ if $V \leq V^{*}$, with $D(V) \geq B$ and $D^{\prime}(V) \leq 0$. The "mildest" form of such a bond is therefore one that promises to pay either cash of B or shares with a current market value of $B$ on the due date. Such bonds have the same elasticity as conventional debt: regardless of how the bonds are paid off, the shareholders receive $V-B$ when $V>B$, and when $V<B$ no number of shares can make the bondholders whole so old equity holders are infinitely diluted and the price per share goes to 0 . It is easy to see that $e$ is even greater for "death spiral" bonds that can convert into shares worth more than B at share prices below the conversion price, ${ }^{68}$ so the downward spiral is even worse than with conventional debt.

Sale of put options against the firm's stock. Consider a firm that has sold put options convertible into $p$ times the number of shares currently outstanding (e.g., with 5 million shares outstanding, and 1 million puts sold, $p=0.2$ ), and for which the puts are exercisable at a price that values the existing equity at $\mathrm{X}$. So if $V>X$ the puts are worthless, so the shareholders own the whole firm, and the elasticity of share value with respect to $\mathrm{V}$ equals 1 . But if $V<X$, then also $S<X$, and the puts are worth $p(X-S)$. Since the total value of puts plus equity equals $V$, we have $p(X-S)+S=V$, so $S=(V-p X) /(1-p)$ and $e=V /(V-p X)$. So the downward spiral is exactly as if the firm had conventional debt with face value equal to $p X$.

$E R N s$. A firm with one type of ERN (all due imminently) must pay either $\mathrm{B}$ in cash, or new shares equal to $p$ times the number of shares currently outstanding, for some $p$, (whichever is worth less). Paying in shares leaves the old shareholders with $\frac{V}{1+p}$, so $S=\max \left(\frac{V}{1+p}, V-B\right)$. So when the ERNs are not converted, $e=\frac{V}{V-B}$ just as with conventional debt. But for $\left(\frac{V}{1+p}\right)>(V-B)<=>V<B(1+p) / p<$ $=>S<B / p$, that is, for all sufficiently low share prices, the ERNs will be converted and $e=1$--exactly as for a firm financed entirely by equity.

\footnotetext{
${ }^{67}$ That is, $e$ is the percentage change in share price per one percent change in firm value.

${ }^{68}$ The elasticity is $e=\left(1-D^{\prime}(V)\right) V /(V-D(V)) \geq V /(V-B)$, for $V \leq V^{*}$.
} 
So the first three of these capital structures (including conventional debt) are always sensitive to downward-spiral problems, but ERNs are robust against such problems at low share prices. ${ }^{69}$

\section{(ii) Imperfect Capital Markets}

The preceding analysis implicitly assumes a conventional "Modigliani-Miller/Arrow-Debreu" world in which the total value of all the claims against the firm is independent of how the firm is financed; total risk within the firm is constant, and ERNs just reallocate some of that risk from shareholders to bondholders making the shares safer. ${ }^{70}$

In spite of this, a possible concern is that--in contradiction to modern financial theory--there might be a downward-sloping demand curve for stock, so that conversions of ERNs into equity which increase the total supply of shares thereby also reduce the share price and subsequently cause more conversions. A downward-spiral argument might then go: "Say that debt is convertible when shares are valued at or below $\$ 100$, and the shares "should" be worth $\$ 110$, but short sellers push their price down to $\$ 90$ and force the firm to make a payment in shares. Because of a downward-sloping demand curve for shares (and perhaps because of a reduced debt/equity ratio that transfers value to the remaining bondholders) the low share price is locked in by the increased supply of shares."

But the evidence suggests that demand curve for shares are not that steep. ${ }^{71}$

Furthermore, since conversions are only payment-at-a-time, banks can minimize any potential problems by issuing ERNs that are only repaid gradually, and to some extent we would require banks to do this through the term structure requirements outlined in section $3 \mathrm{~b}$.

${ }^{69}$ Numerical examples illustrate the analysis (letting $s=$ price per share):

Conventional debt: 800 shares, $B=20,000$. If $\mathrm{V}=50,000$, then $800 \mathrm{~s}+20,000=50,000$, so $\mathrm{s}=37.50$. If $\mathrm{V}$ falls to 30,000 , then $s=12.5$; and if $V$ falls to 20,000 , then $s=0$.

Death-spiral bonds. 800 shares, $B=20,000$. If the bonds are convertible into shares with a face value of $B$ then, as above, if $V=50,000$, then $s=37.50$. If $V$ falls to 30,000 , then $s=12.5$; and if $V$ falls to 20,000 , then $s \rightarrow 0$. If instead the bonds were convertible into shares worth 25,000 (i.e., $125 \%$ of $B$ ), if $s<25$ then $s$ would fall discontinuously from 25 to 18.75 at $\mathrm{V}=40,000$, and fall to zero at $\mathrm{V}=25,000$.

Sale of put options against the firm's stock: 1000 shares, 200 European puts exercisable against the firm at $100, B=0$. If $V=50,000$, then $1000 s+200(100-s)=50,000$, so $s=37.50$. If $V$ falls to 30,000 , then $s=12.5$; and if $V$ falls to 20,000 , then $s$ falls to 0 , as lower asset values reduce $s$, so increasing the value of puts which further reduce $s$.

ERNs: $3331 / 3$ shares, $\mathrm{B}=50,000$ which the firm has the right to convert into 1000 shares. If $\mathrm{V}=50,000$, then all the warrants are converted and $(3331 / 3+1000) s=50,000$, so $s=37.50$. However, if $V$ falls to 30,000 , then $(3331 / 3+1000) s=30,000$, so $s=22.5$; and if $V$ falls to 20,000 , then $(3331 / 3$ $+1000) s=20,000$, so $s=15$.

Conversely, if $\mathrm{V}$ rises to 100,000 , then s rises to 100 in the first four cases, but to 75 with ERNs.

So ERNs give the least volatile stock price, and the greatest protection against downward spirals.

${ }^{70}$ Modigliani and Miller actually consider deadweight bankruptcy costs of debt that would tend to favor structures like ERNs that eliminate those costs. On the other hand, not being able to write a hard debt contract may create its own inefficiencies.

${ }^{71}$ For example, Field and Hanka's (2001) study of IPO lockup expirations showed abnormal returns of $-2.7 \%$ in the period from 5 days before until 50 days after expiration as the number of shares free to trade tripled and trading volume increased by 40 percent. So even a large increase in trading float may perhaps cause a price drop of a few percent. 
Moreover, a dramatic price decline is implausible, because the firm might easily reverse it. If $\$ 90$ million is paid in stock is paid on a particular day, the alternative would have been for the firm to pay more than $\$ 90$ million in cash. So the firm could use the cash it saved to repurchase all the shares that it issued and more, thereby pushing the share price at least back up to its initial level. Since the bank has the choice whether or not to leave the new shares outstanding, it must be better off than if it paid cash. ${ }^{72}$ The anticipation of a possible repurchase would likely prevent a price decline from ever occurring. ${ }^{73}$

Finally, ERNs provide extra protections against downward spirals, whether or not capital markets are efficient.

\section{(iii) Additional protection that ERNs provide against downward spirals}

As we explained in section 3b, ERNs become cheaper to issue when the stock price falls (because newlyissued debt will be more senior to old ERNs). Raising additional capital at low stock prices is therefore easy. Raising it through ERNs also transfers wealth to shareholders, further bolstering the stock price. The larger the share price decline, the larger these effects.

Moreover, since our design means companies never have to pay cash, they cannot be pushed into a liquidity crisis which might, for example, lead to value-destroying fire-sales of assets (see section $4 b$ ).

From a public-policy standpoint we are not directly concerned with whether bank shares are trading below "fair" or "intrinsic" value--we care about whether a low share price causes the bank to have trouble funding itself. But by making it easy and profitable to issue ERNs in bad times, and by ensuring companies never have to pay cash, our design also makes aberrantly low share prices less likely.

\section{(iv) Other issues}

A design mistake in many coco proposals is to force conversion of the entire bond on the day a trigger is breached, even if no payment is due that day. Because the owner of a promised repayment will actually receive the minimum of the amount due and the share price, early conversion always helps bondholders at the expense of shareholders, because now they have a claim worth the full share price. So there can be two equilibria associated with the same firm value --- one with early conversion and a share price below the trigger, and one without early conversion and a share price above the trigger (see Sundaresen and Wang, 2010). But with ERNs there is never early conversion, and on the payment date the bondholder always gets a less valuable return if the share price ends up below the conversion level. ${ }^{74}$

Finally, Hillion and Vermaelen (2004) observe that most issuers of the convertible bonds they studied were already in some financial distress, so issuance provided a negative signal. Our proposal has no

\footnotetext{
${ }^{72}$ However, firms would not be allowed to repurchase ERNs or exchange them for new ERNs with greater seniority without regulatory approval. Firms could institute share buyback plans as they do now, but could not make firm commitments to execute these plans.

${ }^{73}$ Further counteracting the effects of any possible short-selling, we would allow investors to take a 6month zero interest deferral of a stock payment as an alternative to receiving equity (see footnote 46). This option would generally seem unattractive to creditors, but might address the concern of investors who thought the stock was temporarily underpriced because of a downward sloping demand curve but at the same time were prohibited from holding stock.

${ }^{74}$ Theoretically it is possible that selling stock at an above-market price through an ERN conversion can cause the stock to fall by reducing leverage and transferring wealth from shareholders to bondholders, but this ignores the possibilities discussed above of issuing new ERNs and repurchasing stock.
} 
signaling problem, since it makes ERNs effectively mandatory for SIFIs and gives them a large incentive to issue more ERNs. ${ }^{75}$

\section{b. Asset-Price Spirals and Liquidity Spirals}

A potential concern for any system is whether banks (or other SIFIs) can be pushed into a crisis by a downward price shock, increases on haircuts on collateral, or difficulties in rolling over unsecured capital. The fear is that any of these things might force banks to sell assets or reduce new investment (that is, create "contagion", as declines in one market cause investors to liquidate assets in other markets to meet margin requirements) and leading to a "downward spiral" as prices fall until the market finds a new equilibrium. ${ }^{76}$ Our plan helps prevent such crises.

By construction our system rules out solvency crises: first, our requirement that all guaranteed creditors must be fully backed by government securities assures that there are always enough funds to pay them

${ }^{75}$ The sellers in Hillion and Vermaelen's study were also overwhelmingly small firms whose shares were relatively illiquid. This may have magnified the problems created by the design flaws of the kinds discussed at the beginning of this subsection.

${ }^{76}$ A fully levered firm can be thought of as obeying the equation $U=p Q h$ where $U$ is unsecured capital, $p$ is the price of assets, $Q$ is the quantity of assets held and $h$ is the haircut applied by secured creditors. So $Q=U / p h$, and since $d U / d p=Q$ (a one unit increase in the price of assets creates a profit of $Q$ ), $d Q / d p=$ $(Q-(U / p)) / p h=(Q / p)(1-h) / h$ so the elasticity of asset holdings with respect to asset price is $(d Q / d p) /(Q / p)$ $=(1-h) / h$. That is, for every one percent decline in asset prices the capacity to hold assets, even at the lower price, falls by (1-h)/ $h$ percent. Similarly, a one percent increase in $h$ causes a one percent decline in the ability to hold assets, prices held constant. In Shleifer and Vishny (1997), when $p$ falls there is a further decline in $U$ as uninformed investors withdraw funds after observing poor performance, causing a further decline, even as experts know that prices will eventually revert, Geanakoplos (2009) demonstrates the possibility of bad news causing a decline in $p$ that exceeds the amount that any individual holder believes is warranted, as the decline wipes out the capital of the most optimistic holders and increases the required haircuts demanded of new buyers because of increasing asset price volatility. Gorton (2009) argues that the crisis began with a "repo run" --- a sudden increase in haircuts -- against "shadow banks". However, Copeland et al. (2012) show that haircuts remained fairly constant in tri-party repo. Krishnamurthy et al. (2011)) show that haircuts for weaker collateral such as nonagency mortgage backed securities did rise in the bilateral repo market, but this collateral represented a small share of the market and probably had a market value that had fallen relative to book, increased riskiness, and reduced liquidity (so justifying higher haircuts). Interestingly, at the height of the crisis it was possible to borrow against equity securities with a 10 percent haircut; for example see this filing from Fidelity Money Market Trust. Furthermore, if the suppliers of capital were financially weakened then they would have been expected to supply more collateral for the same loan, as in the case of a firm whose credit rating is downgraded. One would generally expect bilateral loans to decline significantly when financial firms become weaker: it is impossible for both firms to post excess collateral to one another without a tri-party agreement (e.g. if Lehman lends Bear 970 against 1000 in securities then Bear will necessarily have an unsecured risk with Lehman, and firms may choose to simplify balance sheets by eliminating offsetting positions. However, because collateralized lending would likely be much more pervasive for less liquid assets in our system, we need to recognize the possibility of an increase in equilibrium haircuts. 
off. Maximally-levered banks must raise unsecured capital or sell assets as losses are incurred rather than all at once in a crisis. ${ }^{77}$ Second, none of a bank's lenders can force it into a default.

Eliminating the possibility of a solvency crisis also greatly reduces the probability of a liquidity crisis: even in bad times creditors need only worry whether the collateral posted to them is adequate, and not whether a loss of general confidence in the bank will leave them with money tied up in a bankrupt firm, so we would not expect to see a troubled firm suffer a sudden loss in secured funding. Also, unsecured funding is all long-term ERNs and equity. So a loss of confidence will not trigger a run of either secured or unsecured debt. Furthermore, when declining asset prices and reduced demand for bank securities give the bank the choice between selling assets and raising new unsecured capital, our system makes raising new funds more attractive, especially when the decline in asset prices is large, because ERNs are cheaper in bad times.

Moreover, even if banks do "put" assets to lenders who re-sell them, any downward pressure on prices is reduced, because banks' losses are mitigated by ERNs. That is, because the banks will both lose less and find it easier to raise new unsecured capital, there will be less downward pressure on prices, even if a new lower equilibrium price level must be found at which the banks will retain all the assets.

Finally, if even so, a bank has problems finding the necessary funds to avoid losing or having to sell assets it posted as collateral the central bank can if it wishes make collateralized loans backed by assets and ERNs; that is, central bankers can make traditional lender-of-last-resort liquidity loans. ${ }^{78}$

\section{c. Liquidity Provision}

Consumers and businesses obtain liquidity both when they make short-term safe deposits in a bank, and when they borrow long from the bank. Maturity is transformed for depositors, and both depositors and borrowers face less risk. But under the current regulatory system these services are in reality provided by the government insurer rather than the commercial banks.

For a depositor this is obvious: the depositor is given a government-guaranteed claim whose value is unaffected by the financial strength of the bank.

\footnotetext{
${ }^{77}$ That is, they cannot take advantage of slow-moving regulatory capital to delay action. However, our system does not automatically require reserves held to be in proportion to market values. A bank may not be required by its lender to post enough additional capital to maintain a constant percentage margin, either because of a long-term contract, or because the lender feels comfortable lending a higher percentage of a lower price. (Of course, if an asset becomes riskier, then secured lenders are likely to demand an increased "haircut".)

${ }^{78}$ At least since Friedman and Schwartz (1963) economists have modeled a bank run as the withdrawal of assets from an otherwise-solvent bank that forces it to sell assets at below-market "fire sale" prices leading to an insolvency that could have been prevented by a lender of last resort offering short-term funding against good collateral, with minimal risk to the taxpayer (see, e.g., Diamond and Dybvig (1983) and Morris and Shin (2003)). But more recently deposit insurance has allowed banks to continue operating well past insolvency, and the concern has been that the withdrawal of private unsecured and uninsured funding could force a bank to sell assets at prices that are below regulatory value (but might reflect market value), with the recognition of losses leading to the bank's failure. So "lender of last resort" has come to be a euphemism for bailout agency, and such financing has piled more risk on to the tax payer.
} 
A borrower from the bank, on the other hand, receives liquidity in the form of not being required to post additional margin to compensate for changes in its financial condition, including a decline in the value of collateral. For example, a home buyer with a mortgage may not have to post additional collateral if the appraisal value of the house falls. But if the homeowner transfers some of the risk of a housing price decline, someone else must take it. ${ }^{79}$ Banks could bear the full risk themselves either if they were sufficiently well funded, or if they raised new risk-absorbing capital as their risks increased. However, under a regulatory capital system it is difficult to tell when a bank is well funded, and banks strongly resist raising risk capital when asset prices have declined: in reality, therefore, banks offload a large part of their risk via the cheap tail risk insurance provided by the government.

In our system government guarantees will still be available through the direct or indirect purchase of government-backed securities. Beyond that, our system allows a bank to provide liquidity in virtually any way that relies on its balance sheet rather than the government's.

As the government stops providing risk transfer and other services on a highly subsidized basis, it is to be expected that the private market will increase its provision. Banks could provide risk transfer and liquidity to borrowers with loans financed by private capital. Short-term very low risk claims against banks will still be available through secured loans and through senior claims against pools of ERNs. Riskless claims against banks could be constructed through a combination of ERNS and put options (see section $3 \mathrm{~b}$ ). These claims would be available to smaller investors through non-guaranteed money market funds (reformed as discussed in section 3d). Because our system relies on banks replenishing capital through senior ERNs rather than junior equity, it makes the private options for the replenishment of unsecured capital less expensive and so more credible. ${ }^{80}$

Merton and Bodie (1993) argued twenty years ago that "There may have been, at one time, synergy created by using insured deposits as the primary source to finance the commercial lending activity of banks, but we see no evidence that such benefits, if any, exist in today's financial system." The more liquid capital markets of today make their claim even more compelling.

\section{d. Bank and SIFI Failure}

One of the important advantages of capitalism is the ability of firms to fail. Our plan allows banks and other SIFIs to go out of business - but with a whimper, rather than a bang.

A bank with a reputation for dissipating assets will find it hard to raise new funds. So it will gradually decline as the value of unsecured claims falls over time through payouts and dissipation. Consider, for example, a completely entrenched management that always earns a (risk-adjusted expected) rate of return on assets below the market rate. Since the bank must offer new investors a fair rate of return, it

\footnotetext{
${ }^{79}$ To be more specific, say a borrower takes out a mortgage for 80 against a building worth 100 , but is not required to provide additional collateral if the building's value falls to 85 . As at this point the bank might only be willing to issue a new mortgage for, say, 68 (80 percent of 85 ), it effectively agreed, as part of the original contract, to provide an unsecured long-term loan of 12 to make up the difference. This contingent unsecured loan provides liquidity to the borrower--but in reality it is the government who is providing that liquidity through the tail-risk insurance it gives the bank.

${ }^{80}$ There is also an incentive in our system for banks to develop more liquid markets for secured borrowing against illiquid assets. In the current system banks may sometimes prefer that assets be treated as illiquid so that there is greater discretion in valuation.
} 
cannot finance a program that will allow it to lose more (in present value) than the total value of its assets less the value of any safe secured claims. ${ }^{81} 82$

Under the conventional bankruptcy system, with no government guarantees, debt financing restricts the ability of management to dissipate assets before reorganization. For example, unsecured creditors can recapture half of their claims in the average U.S. bankruptcy. ${ }^{83}$ Under our system, because of the ability to issue new senior debt as value falls, managements could in equilibrium dissipate all assets available for unsecured claims. This may be a reason why our system is not used by nonfinancial firms. ${ }^{84}$

By contrast, the current regulatory system allows banks to lose much more than equity capital plus unsecured and uninsured debt: over the history of the FDIC, the average bank that failed wiped out 15 percent of assets in addition to unsecured (and uninsured) private capital. Considering the regulatory capital ratio of the average "well-capitalized" bank, this means that in the current system banks can lose a multiple of the amount privately at risk. So by limiting losses to 100 percent of private unsecured investment, our system actually reduces entrenchment in the banking sector.

Furthermore, even financial firms that are not explicitly insured may not be allowed to fail in the future. Will any government be willing to experiment with another failure like Lehman? If not, the alternatives are banning such firms as "too big to fail", or constraining them to operate under conditions that, like our proposal, allow them to fade away. So while our system may allow banks and other SIFIs to dissipate more assets than a non-financial firm without government support, it reduces potential dissipation relative to the current bank regulatory regime.

${ }^{81}$ That is, the firm must run a discounted primary surplus in the future, paying out more than it receives, to have a positive stock price. By way of example, consider a firm that has assets worth $\mathbf{3 0}$ more than its safe secured debt. It somehow commits to paying out $x>0$ percent of assets each year in interest and dividends to existing investors (both stock and bond). However, it also dissipates $y>0$ percent of assets every year. It can issue new securities each year, but new investors understand the equilibrium and so cannot be ripped off. Then in order to make the new securities get a fair return (and leave the existing investors with a stock price of at least zero) the firm cannot raise more than $y=x$ percent per year. For example, say that the firm paid out 5 percent per year and wasted 2 percent. It also raised 4 percent per year externally. Then the value of the current stakeholders' claims would be the present value of all future net payouts (since future investors breakeven) or $V=30((.05-.04) /(.05-.04+.02))=10$ and the present value of future dissipation is 20 . Future investors will put in 20 and receive 20 back, or three times as much per dollar invested as old investors receive. As the net payout rate approaches zero the value of shares, and the return to old investors, approaches zero.

${ }^{82} \mathrm{An}$ analogy is to the financing of countries like the U.S. and U.K. that can issue bonds backed by their own currencies. These countries do not have a blank check, as they will be constrained by the need to provide investors confidence they will get a fair return on their investment --- a constraint that prevents many other countries from borrowing very much money in their currencies. Here, companies are able to pay their debts with their own "currencies" of ERNs and shares; nevertheless they will not be able to raise and dissipate infinite sums, and if there is little confidence in management, then they may have trouble selling securities that would be senior at the time of issuance but could be junior later on.

${ }^{83}$ See Standard and Poor's (2011) which reports average recovery rates of 51\% in 1987-2011, ranging from 78 percent for revolving loans to 22.7 percent for non-senior subordinated bonds.

${ }^{84}$ Other reasons include the likelihood that ERNs would not be treated as debt under current tax law, and that firms that voluntarily converted all their new debt financing to ERNs without regulatory coordination would send a negative signal relative to issuing conventional debt. 
In our system a firm that performs badly will see conversions of ERNs to shares that gradually hand over control of the firm to new owners-a slow-motion version of the way the current bankruptcy system changes control. This will likely provide considerable discipline on management-and more than under the current regime for SIFIs that are not allowed to fail. Of course, even the current system has not protected many SIFIs' managements: the heads of Citigroup, Bank of America, Merrill Lynch (twice), Northern Rock, HBOS, and RBS and many other banks were replaced during the recent crisis.

\section{ERNs, Bond Yields, and Capital Structure}

\section{a. Bond Yields and Capital Structure}

In a Modigliani-Miller/Arrow-Debreu world, holding bank assets and liabilities constant with the new capital structure, banks' aggregate increase in financing costs would exactly equal their loss of government subsidy through deposit insurance. For example, say that U.S. banks currently pay .1 percent of assets for insurance that de facto guarantees all securities not counted towards regulatory equity, and the market would charge three times as much. Then the banks' weighted average cost of capital would rise by 20 basis points.

If a bank chose a capital structure that made equity as risky as it currently is and secured debt was safe then ERNs would be left to bear the entire risk currently borne by deposit insurance. If 20 percent of a balance sheet consisted of ERNs (with the rest equity and secured debt) then ERNs themselves would sell at yield spreads of about 150 basis points relative to riskless assets, under the assumptions of the previous paragraph. ${ }^{85}$ If less secured borrowing were possible so that 30 percent of financing was ERNs then the yield spread would be 100 basis points. ${ }^{86}$

In the absence of government insurance, banks could make ERNs no riskier than current unsecured debt via a relatively small increase in equity. For example, say that in the absence of government insurance a bank today would have 6 percent equity. With ERNs that convert at 25 percent, an increase in equity to at most $6(1 /(1-.25))=8$ percent, with the increase displacing unsecured debt, would make the ERNs as risky as the previous conventional debt. ${ }^{87}$

\footnotetext{
${ }^{85}$ We calculate this by dividing the total assumed value of deposit insurance ( 30 basis points) by the fraction of the capital structure represented by ERNs (20 percent).

${ }^{86}$ For contrast, as of August 6, 2012, the differential between a 5 year CDS against Wells Fargo, the highest rated US bank, and the 5 year CDS against the US Treasury was 44 basis points per year.

${ }^{87}$ Consider a model with a single period, at the end of which the bank will pay the first $D$ in returns to debt holders, and any remaining amount to equity holders. The value of the debt in the bank is initially $d_{0}<D$ and the value of the equity is $e_{0}$. At the end of the period the bank will have the random value $V$. Then with strict priority, debt holders will receive a payoff of $\min \{\mathrm{V} / \mathrm{D}, 1\}$ per dollar promised and shareholders will receive $\max \left\{0,(V-D) / e_{0}\right\}$ per dollar of equity. With ERNs, creditors start sharing losses earlier. Say that debt can be converted into equity at a price of $\alpha$ times the initial price. Then if the bank wishes to issue debt with the same payoff as in the conventional case it has to issue debt worth $d^{*}=d_{0}$ $d_{0} \alpha e_{0} /\left(D-\alpha d_{0}\right)$ and equity worth $e^{*}=e_{0}+d_{0} \alpha e_{0} /\left(D-\alpha d_{0}\right)<e_{0}(1 /(1-\alpha))$.

As before, creditors receive $\min \{V / D, 1\}$ per dollar promised. Equity holders receive $\max \{\alpha V / D$, $\left.(V-D) / e^{*}\right\}$ per dollar invested. An investor who wished to replicate the returns from one dollar of old equity could do so by purchasing $e^{*} / e_{0}$ dollars of new equity and selling short $\left(e^{*}-e_{0}\right) / e_{0}$ dollars of ERNs.
} 
In a Modigliani-Miller/Arrow-Debreu world the increase in equity issuance would be just offset by the reduction in the equity risk premium so that the total cost of capital would remain unchanged. This calculation does not account for the effect of future, possibly more senior, debt issuance, ${ }^{88}$ butprobably much more significant for the real cost of capital--it also makes no allowance for the elimination of bankruptcy costs that conventional creditors may bear in the current system. If our plan is efficient and stabilizing, then the overall effect, net of insurance subsidies, will be to reduce the total cost of capital.

\section{b. How ERNs would have worked in 2008-9}

While we do not know how the path of stock prices would have differed from the one followed in 20089 if we had had ERNs at the time, we can say what would have happened to the ERNs of large banks had the path of stock prices been unchanged.

The stocks of three relatively well-capitalized major U.S. banks---J.P. Morgan, Wells Fargo, and Goldman Sachs---closed at less than 25 percent of their all-time highs on zero to four days during the crisis. Therefore it is unlikely that those banks would have made any payments in stock. However, three other major banks---Citigroup, Bank of America, and Morgan Stanley---all saw their stocks fall by over 90 percent. ${ }^{89}$ All would have issued a considerable amount of stock, though perhaps less so Morgan Stanley, which managed a quicker recovery than the others. ${ }^{90}$

For example, say a bank has a capitalization of $\$ 348$, of which $d_{0}=\$ 320$ is in conventional debt and $e_{0}=\$ 28$ is equity, and assume the bondholders are promised the first $D=\$ 360$ of returns (which includes interest and principle repayment) and shareholders are due the rest. Then we can reproduce the returns on the conventional debt by ERNs convertible at $\alpha=25 \%$ of the stock price on the issue date if we change the capital structure to: $d^{*}=d_{0}-d_{0} \alpha e_{0} /\left(D-\alpha d_{0}\right)(=\$ 312)$ of ERNs that are promised $\left(d^{*} / d_{0}\right) D$ $(=\$ 351)$ if no conversion takes place, plus $e^{*}=e_{0}+d_{0} \alpha e d\left(D-\alpha d_{0}\right)(=\$ 36)$ of equity. So equity's share of the bank has risen from $7 / 87$ to $9 / 87$. Conversion takes place iff the equity in the ERNed capital structure drops from $\$ 36$ to $\alpha \$ 36=\$ 9$ or less, that is, iff $V$ - $\$ 351<\$ 9$, i.e., $V<\$ 360$, and in this case the debt is converted on the payout date into fraction $\left(d^{*} / d_{0}\right)$ of all the post-conversion equity. Thus whether or not conversion takes place, the $d^{*}$ in ERNs receives fraction $\left(d^{*} / d_{0}\right)$ of the return that the original $d_{0}$ of conventional debt received-the return on $\$ 1$ of ERNs replicates the returns on $\$ 1$ of the original conventional debt. Meanwhile, the equity receives fraction $\left(1-\left(d^{*} / d_{0}\right)\right)$ of the first $\$ 360$ in returns (\$9), worth a risk-adjusted present value of $e^{*}-e_{0}=\$ 8$, plus all the returns above $\$ 360$, worth $\mathrm{e}_{0}=\$ 28$, as before. Buying $\$ 9$ of new stock and selling short $\$ 2$ of ERNs would replicate the returns on $\$ 7$ of old stock.

See Appendix 2 for an analytical description of the values of multiple ERNs in a one period capital structure.

${ }^{88}$ The ability to issue subsidized debt in bad times comes from what is effectively insurance sold by bondholders who supplied money in better times; these creditors will charge for the risk that they will bear. They will charge more if they believe management will strategically time future ERN issues, or make dissipative investments.

${ }^{89}$ Morgan Stanley and Bank of America share prices first recovered to more than 25 percent of previous highs in 2013; Citigroup was still below that level as of June 2013.

${ }^{90}$ Citigroup would have faced similar aggregate dilution with a conversion rate of 10 percent as with 25 percent, but the timing would have been different. At 25 percent a sample calculation (assuming constant unsecured debt of about $\$ 450$ billion and debt with an average duration of 40 months) 
In the U.K. the story was similar. HSBC (the only one of the pre-crisis big five that never seemed likely to need government support) would never have required any conversions. Barclay's, which narrowly avoided taking government money, would have had to make conversions on any debt issued from mid2006 to late 2007 that was still outstanding at the end of 2008, since it traded below 25 percent of its all-time peak for six months from late October, 2008. HBOS was taken over by Lloyd's at a price close to 25 percent of its peak, and weak banks RBS and Lloyd's traded far below 25 percent of their peak prices from October 2008 through the end of 2012.

As stock prices fell and ERNs became more equity-like, the effective leverage of the banks would have been reduced, so the calamitous share price declines of weaker banks overstate the prospective losses of ERN holders. Starting with the same leverage ratio, unsecured bondholders would have taken losses, but not nearly as large as implied by stock price declines. For example, if a bank with 50 in equity and 50 in unsecured debt lost 50 , then equity would be wiped out in a conventional model. With $25 \%$ ERNs, equity would have lost 40 and bondholders 10 , or 20 percent of their investment. ${ }^{91}$

\section{Comparison with Other Plans}

\section{a. All-Equity, or All-Equity-Plus-Non-Recourse Debt}

What might be termed the Modigliani-Miller/Arrow-Debreu approach assumes that (pre-tax) cash flows are independent of capital structure and, with perfect capital markets, so is the value of the firm. ${ }^{92}$ If there are no social costs to issuing more equity, but there is an externality associated with issuing risky debt, then banks should be required to issue enough equity so that their debt is not risky.

At the extreme, one could require banks (and SIFIs) to be funded entirely by equity except for guaranteed deposits which are fully backed by government securities. This system would be as safe as ours in terms of limiting the risk put to the government, but would require a debt-to-equity transition of bank balance sheets rather than a debt-to-debt transition. There are also costs in setting capital requirements too high, as well as too low, as we discuss in the next subsection. Also, importantly, our system facilitates maturity transformation by allowing ERNs to be pooled and "tranched" to create a

suggests that dilution would have been 35 percent in the fourth quarter of 2008, with shares increasing by another 60 percent (compounded) in the first quarter of 2009. At 10 percent there would have been a trivial amount of share conversion in 2008 but shares would have increased by 135 percent in the first quarter of 2009. However, this simple comparison ignores the fact that the stock price path would have been affected by the ERN conversion rate---at a 10 percent rate dilution effectively involves selling large blocks of shares at 40 percent of the price that is received with a 25 percent conversion, and in both cases shares are sold at premiums to the market price.

${ }^{91}$ That is, with debt convertible into equity at one quarter of the initial equity price, the equity holders would end up with one fifth of the bank, worth 10, and the debt holders would be left with shares worth 40.

${ }^{92}$ Miller (1995) recognized that incentives could be influenced by capital structure, giving rise to problems like debt overhang. Of course, any increase in firm value from debt issuance due to a reduction in taxes does not increase efficiency. 
ladder of debt backed by unsecured claims against banks; it might be harder to do this with unlevered bank shares. ${ }^{93}$

Moving away from the extreme, and overcoming these weaknesses of a pure all-equity approach, one might require that all unsecured capital be equity. Debt would be permitted but without recourse beyond specified collateral. This would correspond to a simplified version of our plan that did not permit ERNs in lieu of equity. However, unlike ERNs, non-recourse debt has no secondary (unsecured) claim, based on the general financial strength of the bank, in the event that the value of the collateral falls. ${ }^{94}$ An attractive feature of ERNs is their ability to provide additional insurance to debt in this way.

\section{b. Increasing Equity in the Current System}

In the spirit of the discussion in the previous subsection, Greenspan (2010) proposed a 14 percent equity requirement to meet this goal of making (ordinary) debt close to riskless; ${ }^{95}$ Admati et al. (2010) and Admati and Hellwig (2013) proposed 20 percent. ${ }^{96}$ Basel 3 and other plans also propose changing the calculation of risk-weighted assets.

Such proposals are surely moves in the right direction, but still leave us with something like the current regulatory system, except with different regulatory arbitrage opportunities. Unless capital requirements somehow match what the markets would require of non-banks, regulatory arbitrage opportunities will exist, and bank asset portfolios will be distorted. Assets in categories where the requirements are too high (too low) will be less likely (more likely) to be held by SIFls versus other institutions, just as the current system may favor banks holding illiquid leveraged loans and complex derivatives over liquid publicly traded equity (see section 2a).

Minimum leverage ratios create an ad hoc supplementary capital requirement that effectively imposes the same regulatory haircut on all assets, so may take us even further from economic reality and-at least in the long run--lead to even more manipulation. ${ }^{97}$ For example, Deutsche Bank has announced that it plans to meet leverage requirements by (among other things) applying new regulatory rules for accounting of derivatives (which has no effect on safety) and reducing its cash pile (which makes things worse).${ }^{98}$ So while the imposition of leverage requirements may have a role in forcing banks to raise

${ }^{93}$ Other disadvantages of an all-equity plan relative to ours are that the market for corporate control might not work as well (conversion to ERNs automatically changes control-rights when a firm becomes distressed, in contrast to the all-equity case) and that, if capital markets are imperfect, an "ERNed" capital structure may make it cheaper and easier for investors to obtain securities to their taste.

${ }^{94}$ Another weakness of restricting to strictly non-recourse debt is that it would at least severely limit derivatives trading.

${ }^{95}$ See also comments by Jeremy Stein and N. Gregory Mankiw following the Greenspan paper.

${ }^{96}$ The U.K. Independent Commission on Banking (2011) also moved in the direction of higher equity requirements, proposing equity capital of at least 10 percent of risk-weighted assets and primary loss absorbing capacity of at least 17 to 20 percent, including bail-in bonds and contingent convertible bonds. An extra 3 percent equity could be required if the bank is judged to be insufficiently resolvable. 97. But an advantage of the blunter leverage ratios is that the weights are fixed by the regulator (at 1), rather than by the banks themselves. Haldane (2013) provides examplesof risk weights which were miscalibrated by a factor of 50 , and one case in which the required incremental risk capital required for a hypothetical exposure differed for two banks by a factor of over 1000.

${ }^{98}$ See "Deutsche Bank set to shrink to achieve leverage target" by Daniel Schäfer, Financial Times, July 21, 2013. 
more equity in the short run before they have adjusted to new requirements they are not a long-run solution.

If the capital requirements are subject to manipulation banks may be compelled, for signaling reasons, to continue to try to minimize equity issuance. More generally, these proposals do not, of course, have our countercyclical features. And since some risk of failure remains, the potential for regulatory forbearance also remains. Indeed if the rhetoric that with higher capital requirements debt becomes near-riskless is believed, the incentives for forbearance are even greater, and enforcement may also be taken less seriously. If, on the other hand, risk has been truly eliminated it would be more transparent for depositors to directly hold claims against government securities, as we propose.

Moreover, even a 20 percent capital requirement against reported assets would have left many creditors seriously under-protected. Lehman Brothers Holdings Inc. creditors would still have been left $\$ 100$ billion short, for example. ${ }^{99}$ The "Failure 400" banks that imposed losses on the FDIC from 2008-11, had simpler balance sheets but, unlike Lehman, were not subject to fair value accounting, cost an average of 24.8 percent of assets. ${ }^{100}$ Unsecured depositors of the Bank of Cyprus have been haircut by 47.5 percent (about 11 percent of the bank's assets) and still do not have access to most of the rest of their money, despite the bank having 5 percent core tier 1 capital in its last pre-bailout financial statement. The larger the potential measurement error in regulatory capital, the more capital required to avoid taxpayer risk. If the history discussed in section $2 \mathrm{a}$ is a guide, banks will figure out how to report increasing capital ratios and lower risk weights while taking on increasing risks. Finally, the need for a higher capital ratio is exacerbated by the tendency for regulatory capital to be most overstated in the worst states of the world, when it is most relevant to taxpayer risk.

\section{c. Conventional Contingent Convertible Capital (cocos)}

We have already discussed some of the issues with conventional cocos. ${ }^{101}$ Cocos that convert based on regulatory capital will be subject to the same manipulation as the regulatory capital system itself. Because large amounts of money will be affected by conversions, there will inevitably be lobbying against them. ${ }^{102}$ Furthermore, in tough times there may be pressure to relax accounting standards more generally, as in the Congressional hearings on fair value accounting.

The U.K. Prudential Regulatory Authority has agreed to give more time to Nationwide (a mutual building society) to meet new leverage rules, recognizing that its loan portfolio, which is dominated by residential mortgages with an average loan-to-value ratio of 60 percent, is relatively low risk compared to that of more diversified U.K. lenders. See "Nationwide caught short by regulator on capital requirements" by Sharlene Goff, Financial Times, July 23, 2013.

${ }^{99} \mathrm{LBHI}$ reported $\$ 209$ billion in assets and $\$ 20$ billion in equity in the September 14,2008 balance sheet submitted to U.S. Bankruptcy Court. Creditors are now expected to recover $\$ 65$ billion, which would imply that a 20 percent equity requirement would have left them about $\$ 100$ billion short --- more than can be confidently attributed to even broadly defined "bankruptcy costs".

${ }^{100}$ Data accessed on December 10, 2012. Assets were $\$ 361.6$ billion and losses $\$ 89.8$ billion for these 413 banks, according to FDIC Historical Statistics on Banking.

${ }^{101}$ Two discussions of cocos by regulators are Basel Committee on Banking Supervision (2011) and Financial Oversight Stability Council (2012).

${ }^{102}$ For example, Pennacchi et al. (2010) propose a bond ("COERCs") which has a conversion price based on the ratio of the market value of equity plus convertible bonds to the market value of more senior debt, with the trigger setting off a highly-dilutive rights offering effectively underwritten by the 


\section{d. Bail-in, Living Wills, and Resolution Authority}

"Bail-in" involves mandatory partial conversion of unsecured, non-government guaranteed debt as a way to re-capitalize an insolvent bank or other SIFI, with regulators having discretion about the amount of debt to be converted. "Living wills" help by specifying a general road map to resolve a distressed firm. ${ }^{103}$

Bail-in would have been an excellent resolution or potential resolution for some large banks such as Citigroup. ${ }^{104}$ However, many banks have little such debt, ${ }^{105}$ and unless enough bail-in capital is required in addition to equity, banks will have incentives to minimize such claims in their capital structure, adding more secured debt and unsecured guaranteed deposits instead. And if we are to require a certain amount of regulatory equity plus unsecured (bail-inable) debt, we run into our usual regulatory arbitrage problems. ${ }^{106}$ Furthermore, if living wills and resolution authority are triggered by regulatory values rather than market information, there will inevitably be further incentives for gaming, manipulation, and regulatory arbitrage. Of course, only if all a firm's unsecured debt, including its unsecured deposits, is required to be fully bail-inable, is the firm guaranteed to remain solvent.

By contrast, our system does guarantee that SIFIs stay solvent: ERNs effectively pre-specify (and precisely specify) a compulsory, gentle, "bail-in". Their countercyclical feature also facilitates the rebuilding of capital as the gradual "bail-in" takes place

Also, our system's gradual nature means it creates less sharp conflicts of interest between valuemaximization and shareholder-value-maximization than a standard "bail-in" does. Any plan that requires a sudden, large, adjustment encourages regulators to temporize and "kick the can down the road" as in

bondholders that requires shareholders to either finance the repayment of the debt or award bondholders shares with a market value that may exceed the value of the promised repayment. "COERCs" thus requires the substantial contribution of new capital by shareholders rather than the passive conversion of debt, and so may lead to pressure on regulators to intervene and allow the company to pay cash instead. "COERCs" also differ from ERNs in recognizing losses on a whole bond at once rather than one payment at a time, acting as a junior security in a conventional regulatory framework, and in serving strictly to repay old debts and retain solvency, while ERNs are also designed to provide additional recourse to secured debt, and to create counter-cyclical incentives that make it possible for banks to raise new money relatively cheaply in bad times.

${ }^{103}$ Calello and Ervin (2010) proposed "bail-in". The UK created a Special Resolution Regime (SRR) in 2009 in response to the problems caused by its government's lack of legal powers in the Northern Rock crisis; the UK Financial Services Authority (2011) has recently issued a Consultation Paper on Recovery and Resolution Plans. Similar to resolution regimes, Bulow and Klemperer (2009) proposed converting all non-guaranteed unsecured debt of failing banks into equity, with the government then paying the cost of not converting any explicitly guaranteed debt. One difficulty for the US during the financial crisis is that while the FDIC may take over a bank, there was no clear way forward with a bank holding company. ${ }^{104}$ Similarly, Dexia's unsecured and (theoretically) unguaranteed debt was over five times its regulatory capital at the time it asked that it all be guaranteed.

${ }^{105}$ Most of the US banks that failed (and some large banks that did not, e.g., Wells Fargo) had little such debt.

${ }^{106}$ The proposed Federal Reserve rule requiring banks to shift debt now issued by banks to bank holding companies, to increase the amount of equity in banks and make bank holding company debt more bailinable, would be a step in the right direction. However, lobbyists are already quietly fighting the prospect of such a transfer of risk to the private sector. See Nasiripour (2012). 
the Eurozone crisis. In particular, systems based on regulatory accounting values inevitably require flexibility, since two firms with the same accounting deficits can be economically very different, but such flexibility makes it hard to credibly commit to a plan. So it is hard to imagine a "big bang" bail-in solution in which not only do the regulators have confidence, but also everyone else also has confidence that the regulators will have confidence in it when the time comes to use it. By contrast, our plan smoothes the process and clearly, simply, and unambiguously specifies precisely how and when any partial bail-in takes place. So it is much more credible that private creditors will bear losses when institutions lose money, even at the same time as the institutions can continue operating.

\section{e. $100 \%$ Reserve Banking, and Ring Fencing}

Our proposal for deposits, and for other claims that cannot bear losses, is in the tradition of $100 \%$ reserve proposals made by such distinguished economists as Friedman (1959) and Tobin (1987) ${ }^{107}$ and, strikingly, was one of the few things they seemed to agree on. However, unlike strict "narrow banking" plans, allow banks to also engage in other activities such as risky loan-making.

As in "ring fencing" proposals, such as those as the U.K. Independent Commission on Banking (2011), ${ }^{108}$ claims that cannot bear losses are handled separately from other claims. We discuss in section 7 that ring-fencing deposits might be a good medium-term way station towards our full system. But $100 \%$ reserves also go much further than ring-fencing not only in providing much stronger protection for taxpayers from losses in traditional banking operations, but also in protecting other banking operations from sudden failure, in order to remove them too from implicit, as well as any explicit, government support.

As an institution that did not rely on deposits, Lehman showed that narrow banking alone would not be enough to solve our capital regulation problems. And the failing commercial banks showed that simply "ring fencing" non-traditional activities will not be enough to do the trick either. To the best of our knowledge, none of the US banks which required direct payouts from the FDIC in 2009-11 would have been substantially affected by ring-fencing rules: they all lost money the old-fashioned way, through bad loans. ${ }^{109}$ While a few large banks also engaged in investment banking and trading required significant assistance, most of the problem assets of these firms were also in traditional areas such as consumer lending and real estate. ${ }^{110}$

${ }^{107}$ Our proposal for narrow banking accounts within commercial banks closely follows Tobin's proposal for "deposited currency" fully backed by short-term federal funds and Treasury obligations See James (2007) for an advocacy of, and references to, narrow banking proposals.

${ }^{108}$ The U.S. "Volcker rule" and the E.U.'s Liikanen report are also meant to separate commercial banking activity by ruling out activities such as proprietary trading.

${ }^{109}$ We include losses on mortgage securities and purchases of preferred stock as "bad loans" here.

${ }^{110}$ For example, of the $\$ 300$ billion in Citigroup assets placed in a "ring fence" to cap the bank's potential losses, $\$ 175$ billion was consumer home mortgage loans, $\$ 38$ billion was other loans to consumers and small business, $\$ 20$ billion was in commercial real estate, $\$ 5$ billion was financing of auto companies, $\$ 12$ billion was Alt-A residential mortgage-backed securities, $\$ 6$ billion was in structured investment vehicles, and $\$ 45$ billion in prime and subprime residential mortgage based securities, highly leveraged finance, and other. Against this, Citi had a \$39.5 billion deductible. See SIGTARP (2011). 


\section{f. Insurance against Default}

Kashyap, Rajan, and Stein (2008) propose supplementing capital requirements by requiring banks to buy insurance against default from institutions such as sovereign wealth funds and pension funds, which would be required to put up the face value of the policy in "lock-box" accounts. For example, a bank with $\$ 500$ billion of assets might have the option of increasing its capital by two percent or buying \$10 billion of insurance. The insurers would then have an incentive to monitor the banks' books, and so act as an agent against regulatory forbearance. But questions remain. If a bank begins to get into trouble it might not be able to renew its policy, and this could cause a loss of confidence; insurance has problems of moral hazard and of the credibility of the insurers' promises to pay; and we still have the distortions caused by using regulatory capital requirements.

\section{g. Regulating Maximum CDS Spreads}

A clever proposal by Hart and Zingales (2010) is to require SIFIs to maintain their CDS spreads at no more than a given level, say 100 basis points. This has the virtue of regulating strictly on a marketdetermined number. However, there is obviously no equilibrium in which there is any spread above the risk-free rate and no chance of a default. If there were, an arbitrage would exist at any maximum spread greater than zero. So the proposal must always leave a probability of default. In fact, if it is not certain that unsecured creditors will be wiped out in a default (and this proposal does nothing to make it more credible that the government will not bail out institutions that fail), a maximum CDS spread of 100 basis points might imply a much greater than one percent (risk-adjusted) probability of default. ${ }^{111}$

\section{Transition: Sequencing the Reforms}

The easiest of our reforms is the substitution of ERNs for cocos and similar bail-in capital. If all such capital is counted as equity for regulatory capital purposes, then changing to payment-by-payment conversion has no impact on measures of regulatory capital. It also protects taxpayers as much as full conversion. Importantly, by making equity dilution more gradual it cuts incentives for manipulation, and eliminates any incentive for bondholders to short stocks to force early conversion, so makes market triggers viable. The market triggers and payment-at-a-time conversion reduce the wealth and control transfers caused by any one conversion, reducing incentives for manipulation (or lobbying for regulatory forbearance), and so bring both clarity and credibility to the conversion process. Because each payment is the equivalent of a riskless bond minus a simple equity put option, the equity triggers make the bonds much easier than traditional cocos to hedge. If, in addition, the fixed minimum percentage market triggers that we suggest are used, then the seniority of bonds issued in times of stress is increased, reducing procyclicality.

The second step, which might also not be too hard-see below--would be the replacement of all unsecured debt with ERNs. When the first ERNs are issued they, like other bail-in capital, would be junior to traditional senior unsecured debt, so would be relatively expensive to issue--for ERNs to be

\footnotetext{
${ }^{111}$ Note that it is possible for a bank to have a high CDS because of legal or political risks, even when tangible equity is high relative to liabilities. For example, as of August 8, 2012 five year CDS for Goldman Sachs, a firm that is more conservatively financed than the other top US banks, had averaged (and stood at) over 250 basis points for the previous year. Hart and Zingales differ from conventional regulatory requirements in their implicit requirement that equity be raised to account for such risks.
} 
cheap to issue in bad times (from the perspective of existing shareholders), newly issued ERNs must transfer wealth from more junior creditors without transferring as much to more senior creditors, including the government in its role as deposit insurer. When new ERNs are senior to all existing ERNs, and when also all more senior creditors are already safe (and so unaffected by new ERNs), this must be true. So to ensure the counter-cyclicality of our system, the deposit insurer as well as any other potential creditor with priority over ERNs must be made as safe as possible.

The third step could be to create a "ring fenced" banking subsidiary whose liabilities were limited to deposits, ERNs, and equity, as a stepping stone towards our 100 percent reserve system. Assets in the subsidiary would be "haircut" at rates comparable to those demanded by central banks and the private market for secured lending, ${ }^{112}$ to determine its capital requirement (of ERNs plus equity). The lack of other debt (besides ERNs) within the subsidiary, and the use of market-related haircuts would afford taxpayers protections similar to those of secured lenders. ${ }^{113} \mathrm{~A}$ simplified version of a bank balance sheet would then look like Figure $1:^{114}$

\section{INSERT FIGURE 1 HERE}

Ultimately, however, we would like governments to insure only their own securities-otherwise there would inevitably be pressure to reduce collateral requirements and overstate fair values, and for banks to exploit differences between market and regulatory haircuts. So in the long run we would want to transition to government securities fully backing all deposits, by successively tightening the rules about which assets could be held in the subsidiary.

One way to quickly achieve our second step of replacing all unsecured debt with ERNs, would be to link bank executives' pay to the issuance of equity and ERNs. For example, the sum of dividends, buybacks, and new non-ERN debt, plus pay to individual employees in excess of some cap might be limited to a fraction of the net cash inflow from equity and ERNs sold to private investors until the bank had fully converted. The asymmetric information and debt-overhang problems of selling ERNs and equity while

\footnotetext{
${ }^{112}$ For example, as of this writing the Federal Reserve discount window applies haircuts to estimated fair value of 4 percent to 5-10 year agency mortgages, 16 percent to similar duration AAA private label collateralized mortgage obligations, and 41 percent to credit card receivables. The Bank of England haircuts similar duration residential mortgage-backed securities by 17 percent, and commercial mortgage-backed securities by 30 percent.

${ }^{113}$ Our instinct would be to restrict banks to holding simple-to value assets within the ring-fenced subsidiary. For example, derivatives, even if designed to hedge risk within the ring-fence, would be outside the ring fence (and so would not directly affect ring fence capital requirements). Profits and losses on such derivatives could be moved into and out of the ring fence if the hedge performs as expected. Some hedging through derivatives within the ring-fence, as envisioned by current U.K. policy proposals (see Independent Commission on Banking, 2011) might be appropriate, for example, for a "ring-fenced bank" without an affiliated non-ring fenced operation. (But if a ring-fenced bank with a non-ring fenced parent can create a riskless claim by combining a derivative and an asset, it could take the asset out of the ring fence, borrow against the riskless claim, and use the cash from the loan to back deposits.)

${ }^{114}$ For Figure 1 we ignore issues such as lines of credit and derivatives.
} 
the bank still had substantial debt would be at least partly solved by the market's understanding that even executives whose stock was undervalued would be keen to issue it in order to regain fuller control over their pay. ${ }^{115}$

This is not to understate the magnitude of the full transition, which in the (very) long run would be similar to moving to other $100 \%$ reserve systems. Instead of using cheap deposits to fund risky loans, with tail risk assigned to the government, banks would have to find private investors willing to bear this tail risk. ${ }^{116}$ Losing a market participant (the tax payer) who has been taking the other side of trillions of dollars in swaps of unsecured bank debt for safe assets, and doing so at non-market prices, will be an adjustment that banks will not want to make.

Still, there are two important ways in which transition to our full system would be easier than to others. First, because market systems have inherent flexibility they require lower initial levels of capital to achieve any given level of safety. For example, if an asset's market value never changes by more than three percent per time period, a market capital requirement of three percent will guarantee solvency. If the regulatory system only recognizes 10 percent of the difference between market and accounting capital each period, a 23 percent regulatory requirement would be needed to assure solvency. ${ }^{117}$

Second, there is no reason to demand any increases in current equity, since equity will automatically be created as needed once sufficient ERNs have been issued. Rather, the change would involve transferring risk from the taxpayer to bondholders by fully collateralizing government-guaranteed debt. Financially sound banks should be able to transition to our plan relatively easily, with their overall cost of capital rising or falling only by the difference between the value of the deposit insurance they receive and what they pay for it. Banks that believe they have fortress balance sheets, and that Basel rules require them to issue more risk capital than necessary, will be able to hold less capital if they can find counterparties other than the tax payer to bear their tail risk.

Smaller banks, even if not systemically important, should have to transition to collateralizing all deposits in the same way as large banks, and would face increasing capital requirements against the fraction of deposits not so backed. However, if they would be allowed to fail, they would not have to use ERNs to finance other assets.

\footnotetext{
${ }^{115}$ One telling example of how incentives can work is the bonus scheme adopted for key executives by InBev-Anheuser Busch after their leveraged merger, where bonuses were tied to debt reduction. Debt was then reduced much more quickly than previously anticipated, leading to the payment of huge bonuses. The efficacy of tying recapitalization to pay was also demonstrated when US banks, which were generally deeply reluctant to raise equity, raised more capital than required after the first stress tests-an important reason seems to have been that executives wanted to escape being under the thumb of the TARP program which interfered in their pay.

${ }^{116}$ In theory, investors should recognize that they will be taking on less tail risk indirectly through the government, which should make them be willing to take on more in the private markets, but there will anyway be some redistribution of risk away from people who are affected by the government budget but do not participate much in the capital market.

${ }^{117}$ That is, say a bank had regulatory assets of 100 , market assets of 77 , and liabilities of 77 . If the regulatory capital system recognizes 10 percent of the gap each period and so requires the bank to raise that much money, the amount raised in such a case ( 2.3 percent) would be just enough to offset a potential loss of three percent of the 77 .
} 
Of course, banks that would already be insolvent without a government guarantee would not be able to raise enough capital against their asset bases to replace their government guarantees. There is no magic bullet in our system or any other to return them to solvency without either direct or indirect subsidies, or good luck. Treasuries and central banks could provide backstop equity funding (as in 2008) or purchase ERNs if they wished to keep these institutions from failing. ${ }^{118}$

\section{Conclusion}

The current regulatory system is dysfunctional. Regulators face an impossible burden monitoring an ever more complex regime; rules are easily manipulated, distorting banks' incentives, and making eventual failures extremely costly to taxpayers who bear an inefficiently large amount of risk; and the system is pro-cyclical, discouraging new lending in bad times.

Our solution is, as far as possible, to use the market to determine and enforce capital requirements. This does not mean merely moving to mark-to-market regulatory accounting. Instead we use "ERNs" to clearly and credibly allocate losses-as well as profits--to private investors. The market will then determine both the bank's overall requirement for unsecured medium- and long- term capital and the distribution of that capital between equity and (ERNed) debt, and also re-allocate the risks if doing so is efficient. The fact that we are focused on regulating large banks which sell securities on large, liquid capital markets with opportunities for hedging makes it easier, not harder, to have a straightforward regulatory system that works.

Our system respects an important constraint: sudden collapses of systemically important institutions will not be permitted--and any plan that allows them is simply not credible. Regulators and politicians cannot be counted on to permit failures and, importantly, institutions know this. Our solution is to allow banks to fail, but with a whimper rather than a bang.

We also lean against the pro-cyclical wind, making capital raising - and therefore lending - easier rather than harder in recessions. Counter-cyclicality also increases the credibility of the plan, because there will be no incentive to scrap it in bad times.

ERNs are the key to both these things. They are naturally countercyclical, and they rule out sudden failures of banks and other SIFIs. They also mean that markets, not inevitably gameable regulations, determine banks' access to capital.

Using the market as we do also has important advantages:

First, markets don't forbear. Market forces, in conjunction with ERNs, lead to gradual, and automatic change, by contrast with the current system which often relies on discretionary and discontinuous

${ }^{118}$ One possibility would be to require that as a condition for such financing the bank's other unsecured and uninsured debt had to become convertible into equity under the same terms as the government's ERNs. This approach might be thought radical, although it would still subsidize private lenders-just not as much as they have come to expect. Of course, there would be plenty of opposition to all our proposals. 
changes and can force regulators to choose between all or nothing, with a natural bias towards choosing nothing.

Second, market-based systems are more flexible to changing circumstances. ${ }^{119}$ It is not so hard to design systems that would have worked in the last crisis, just as it is always possible to build models with enough complexity that they perform perfectly in-sample, and generals always have flawless plans for refighting the last war. But will these systems have the flexibility to respond as firms respond to changed incentives? Just as mechanical automobile mileage tests that may have worked well when originally implemented have produced results that increasingly diverge from driver results, a regulatory capital system that would have worked well for 2008-style capital structures may be less effective when it is tested in the 2020s. Any non-market regulatory system will "learn negatively" over time, as firms become more adept at building structures to take advantage of the system. By contrast, after the 1998 collapse of LTCM, collateral requirements evolved, so while hedge funds did de-lever during the crisis, ${ }^{120}$ they needed no bailouts like those for commercial banks. ${ }^{121}$

Third, a market-based system is more immune to lobbying. A market-based system does not rely on ratings agencies, internal bank models, or the categorization of assets for risk weighting purposes --though these things may very well be used by private parties if they wish. Excellent plans are routinely undermined by being slowly chipped away at over time, after politicians (and academics) have lost interest. ${ }^{122}$ While some proposals made by articulate and well-paid bank lawyers and accountants to modify regulations will have validity, it will be difficult for politicians to separate those from proposals that will subtly shift risk to taxpayers.

Fourth, by creating as much consistency as possible between the rules and incentives faced by regulated banks and those faced by unregulated competitors engaged in the same activities, we encourage efficient capital structures, efficient organizational forms, and efficient allocations of activities to companies. Currently, some activities are wrongly in-house; others are wrongly pushed out into a shadow system--any system like today's inevitably sustains regulatory arbitrage as a significant line of business.

${ }^{119}$ In the terminology coined by Taleb (2012) subsequent to the first presentations of our work, markets are naturally "antifragile". Some senior regulators have told us privately that they saw the last crisis coming when bank stocks and asset prices began to fall in 2007, or earlier, but with a sclerotic regulatory system and a political system not well equipped to be responsive to early warning signals, they could not prevent a meltdown in the fall of 2008.

${ }^{120}$ Ang, Gorovyy, and van Ingwen (2011) report that gross leverage in hedge funds declined from 2.6 in June 2007 to a low of 1.4 in March 2009.

${ }^{121}$ By contrast, Tett (2009) describes an April 2007 meeting of G-8 regulators who were not concerned about the heavily regulated banks but were concerned about unregulated hedge funds.

122 John Kay makes this point well in the contexts of both banking, and copyright term extension. (One of us (Klemperer) and Kay unsuccessfully fought the latter. As Kay (2011) explains "The proposal has been beaten off several times by a small group of disinterested people - mainly academics. But they are under-resourced, and have other things to do. The lobbyists, in contrast, are over-resourced and have nothing else to do. Wherever the proposal is rejected, its advocates revive it in another forum at another time. Eventually they get their way. The lobbyists never go away.... since there are many issues in public debate, [the public's] attention to any one is necessarily transient. The attention of vested interests to their own concerns, however, is permanent.") 
Finally, however, and crucially, our system is also robust to market error. We do not require that markets are right--or even as right on average as the models of regulators and bankers. What matters is that the risks of error are allocated to private investors - as they are in our market system. There is no need to distinguish liquidity and solvency crises as banks are always solvent, even as central banks retain the ability-if they wish--to act as lenders of last resort by lending on weaker collateral than the market demands.

For all these reasons, our system broadly mimics the systems used to secure the debts of institutions that are not government guaranteed: our treatment of deposits is not far different from the treatment of money market funds; our treatment of other assets requires the banks to borrow on the same standards that they themselves use in lending to clients. Together with ERNs that credibly convert unsecured debts into equity in times of stress, and prevent sudden collapses, this system eliminates distortionary incentives for regulatory arbitrage, facilitates counter-cyclical raising of unsecured capital, and clearly and credibly assigns losses to private investors where they belong. 


\section{References}

AIG, “Collateral Call Status”, 2008.

Acharya, Viral V., Schnabl, Philipp, and Gustavo Suarez, "Securitization Without Risk Transfer", Journal of Financial Economics, forthcoming. Draft dated September 9, 2010.

Admati, Anat R., DeMarzo, Peter M., Hellwig, Martin F. and Paul Pfleiderer, "Fallacies, Irrelevant Facts, and Myths in the Discussion of Capital Regulation: Why Bank Equity is Not Expensive", Stanford

Graduate School of Business Working Paper, March 23, 2011.

“The Leverage Ratchet Effect", mimeo, July 31, 2013.

Admati, Anat and Martin Hellwig, “The Bankers' New Clothes: What's Wrong with Banking and What to Do about It", Princeton University Press, 2013.

Andrews, Edmund L., "Irregularity Uncovered at IndyMac". The New York Times, December 22, 2008.

Ang, Andrew, Gorovyy, Sergiy, and van Ingwen, Gregory B., "Hedge Fund Leverage", NBER Working Paper 16801, February 2011.

Basel Committee on Banking Supervision, "Global systemically important banks: assessment methodology and the additional loss absorbency requirement: Rules text", November 2011.

"Regulatory consistency assessment programme (RCAP) - Analysis of risk-weighted assets for market risk", January 2013.

Bennett, Rosalind L., Vaughan, Mark D., and Timothy J. Yeager, "Should the FDIC Worry about the FHLB?" 2005. Federal Reserve Bank of Richmond Working Paper No. 05-05.

Brady, Steffanie A., Ken A. Anadu, and Nathaniel R. Cooper, "The Stability of Prime Money Market Mutual Funds: Sponsor Support from 2007 to 2011", Federal Reserve Bank of Boston, Working Paper RPA 12-3, August 13, 2012.

Black, Fischer, Merton H. Miller, and Richard Posner, "An Approach to the Regulation of Bank Holding Companies", Journal of Business, Vol. 51 No.3, July 1978, pp. 379-412.

Bulow, Jeremy and Paul Klemperer, "Reorganising the banks: Focus on the liabilities, not the assets", Voxeu.org, 21 March 2009.

Calello, Paul and Wilson Ervin, "From Bail-out to Bail-in", The Economist, January 28, 2010.

Carver, Laurie, "JP Morgan's 'London Whale' losses spark VAR debate." Risk magazine. Published online only, 14 May 2012.

and Michael Watt, "OCC faces vetting questions over JP Morgan Loss." Risk magazine, Published online only, 31 May 2012.

Chen, Nan, Paul Glasserman, Behzad Nouri and Markus Pelger, "CoCos, Bail-In, and Tail Risk", Office of Financial Research Working Paper \#0004, January 23, 2013. 
Committee of European Banking Supervisors, "European Banking Authority 2011 EU-Wide Stress Test Aggregate Report" 15 July 2011. See also individual bank results and other data.

Cook, Timothy Q. and Jeremy G. Duffield, “Money Market Mutual Funds and other Short-term Investment Pools", Federal Reserve Bank of Richmond, 1998.

Copeland, Adam, Martin, Antoine, and Michael Walker, revised March 2012, "Repo Runs: Evidence from the Tri-Party Repo Market", Federal Reserve Bank of New York Staff Reports, no. 506.

Cox, Christopher, "Chairman Cox Letter to Basel Committee in Support of New Guidance on Liquidity Management", 2008.

Diamond, Douglas W. and Philip H. Dybvig, "Bank Runs, Deposit Insurance, and Liquidity", Journal of Political Economy, June 1983, vol. 91, no. 3, pp. 401-19.

Diamond, Douglas W., and Zhiguo He. A theory of debt maturity: the long and short of debt overhang. No. w18160. National Bureau of Economic Research, 2012.

Department of the Treasury Office of the Comptroller of the Currency, Board of Governors of the Federal Reserve System, and Federal Deposit Insurance Corporation, "Regulatory Capital Rules: Standardized Approach for Risk-weighted Assets; Market Discipline and Disclosure Requirements" joint notice of proposed rulemaking. 2012.

Duarte, Estaban (2012), “European Banks Bolster Capital With Shunned Bonds: Mortgages”, Bloomberg News, July 1.

Ellul, Andrew, Chotibhak Jotikasthira, Christian T. Lundblad and Yihui Wang, "Is Historical Accounting a Panacea? Market Stress, Incentive Distortions, and Gains Trading", February 21, 2012.

European Central Bank, “Developments In Banks' Liquidity Profile And Management”, May 2002.

Federal Deposit Insurance Corporation, "Study on Core Deposits and Brokered Deposits", July 8, 2011.

, “FDIC Quarterly", 2012, Volume 6, Number 1.

Federal Home Loan Banks Office of Finance, "Federal Home Loan Banking System Lending and Collateral Q\&A" August 13, 2013.

Federal Reserve Board of Governors, "Comprehensive Capital Analysis and Review 2012: Methodology and Results for Stress Scenario Projections", March 13, 2012

Field, Laura Casares, and Gordon Hanka, "The Expiration of IPO Share Lockups", The Journal of Finance, Vol. 56 Issue 2, pp. 471-500, April 2001.

Financial Accounting Standards Board, "Amendments to the Impairment and Interest Income Measurement Guidance of EITF Issue No. 99-20" FASB Staff Position No. EITF 99-20-1, January 12, 2009.

Financial Stability Oversight Council, "Report to Congress on Study of a Contingent Capital Requirement for Certain Nonbank Financial Companies and Bank Holding Companies", July 2012.

Financial Services Authority, "Recovery and Resolution Plans", Consultation Paper CP11/16, August 2011. 
Financial Services Authority (FSA) Board Report, "The failure of the Royal Bank of Scotland", 12 December 2011.

Fisher, Irving, “100\% Money”, New York: Adelphi Company, 1935.

Flannery, Mark J., "No Pain, No Gain? Effecting Market Discipline via 'Reverse Convertible Debentures'” in H.S. Scott (ed.), Capital Adequacy Beyond Basel; Banking, Securities, and Insurance, Oxford University Press, November 2002.

Friedman, Milton, A Program for Monetary Stability, Fordham University Press, 1959, pp. 65-76. and Anna Jacobson Schwartz, “A Monetary History of the United States, 1867-1960", Princeton, N.J., Princeton University Press, 1963.

Geanakoplos, John, "The Leverage Cycle." In D. Acemoglu, K. Rogoff and M. Woodford, eds., NBER Macroeconomic Annual 2009, vol. 24: 1-65, University of Chicago Press.

, "What's Missing from Macroeconomics: Endogenous Leverage and Default," in Marek Jarocinski, Frank Smets, and Christian Thimann (eds.), Approaches to Monetary Policy Revisited -- Lesson from the Crisis, Sixth ECB Central Banking Conference, November 18-19, 2010, European Central Bank, 2011, pp. 220-238.

Glasserman, Paul and Behzad Nouri, "Contingent capital with a capital-ratio trigger". Management Science 58, pp. 1816-33. Printed online April 27, 2012.

Goff, Sharlene, “Ministers hesitate on diluting bank reform”, Financial Times, October 12, 2012.

Goldman Sachs, "Morgan Stanley \& Co. Reiterate Our Conviction Buy on Exaggerated Market Fears, September 19, 2008.

, “Valuation \& Pricing Related to Transactions with AIG" 2009.

Gorton, Gary B., "Slapped by the Invisible Hand: The Panic of 2007", Oxford University Press, February 2010.

Greenspan, Alan, “The Crisis", Brookings Papers on Economic Activity, Spring 2010, pp. 201-246.

Haldane, Andrew, "Capital Discipline", based on a speech given at the American Economic Association, January 11, 2011.

Haldane, Andrew G., "Constraining discretion in bank regulation", speech given at the Federal Reserve Bank of Atlanta Conference on 'Maintaining Financial Stability: Holding a Tiger by the Tail(s)', Federal Reserve Bank of Atlanta, April 9, 2013.

Hart, Oliver and John Moore, "Debt and Seniority: An Analysis of the Role of Hard Claims in Constraining Management", The American Economic Review, Vol. 85, No. 3 (Jun., 1995), pp. 567-585

Hart, Oliver and Luigi Zingales, "A New Capital Regulation for Large Financial Institutions" revised August 2010.

Hillion, Pierre and Theo Vermaelen, "Death Spiral Convertibles", Journal of Financial Economics, Vol. 71, No. 2, February 2004, pp. 381-415. 
Independent Commission on Banking, "Final Report: Recommendations", September 2011.

Investment Company Institute, "Pricing of U.S. Money Market Funds", January 2011.

James, Kevin R., “The Case for Narrow Banking”, Bank of England slide presentation, 2007.

JPMorgan Chase \& Co., "Report of JPMorgan Chase \& Co. Management Task Force Regarding $2012 \mathrm{ClO}$ Losses." 2013.

Kashyap, Anil K., Rajan, Raghuram G., and Jeremy C. Stein, "Rethinking Capital Regulation", Paper prepared for the Federal Reserve Bank of Kansas City symposium on "Maintaining Stability in a Changing Financial System", Jackson Hole, Wyoming, August 21-23, 2008.

Kay, John, “Don't listen to lobbyists: they never go away”, Financial Times, 21 September 2011.

Keoun, Bradley and Christine Harper, “Merrill to Sell \$8.5 Billion of Stock, Unload CDOs", Bloomberg, July 29, 2008.

Kiyotaki, Nobuhiro \& John Moore (1997), "Credit Cycles", Journal of Political Economy 105 (2), pp. 211248.

Krishnamurthy, Arvind, Nagel, Stefan, and Dmitri Orlov, "Sizing Up Repo", June 2011, Stanford University.

Kroeker, James L., "Testimony Concerning Exploring the Balance Between Increased Credit Availability and Prudent Lending Standards", March 25, 2009.

Lamont, Owen. "Corporate-debt overhang and macroeconomic expectations." The American Economic Review (1995): 1106-1117.

Laux, Christian and Christian Leuz, "Did Fair Value Accounting Contribute to the Financial Crisis?", Journal of Economic Perspectives, 24 (1), Winter 2010, pp. 93-118.

Le Leslé, Vanessa and Sofiya Avramova, "Revisiting Risk Weights: Why Do RWAs Differ Across Countries and What Can Be Done About It?", IMF Working Paper, March 2012.

Lehman Brothers, “Capital Adequacy Review”, September 11, 2008.

Liikanen, Erkki, "High-level Expert Group on reforming the structure of the EU banking sector", Final Report, Brussels, 2 October 2012.

Mariathasan, Mike and Ouarda Merrouche, "The Manipulation of Basel Risk Weights, Evidence from 2007-10", University of Oxford Discussion Paper Series No. 621, September 2012.

McLean, Bethany and Joe Nocera, "All the Devils are Here: The Hidden History of the Financial Crisis", Portfolio Hardcover, 2010.

McSheehy, Will and Hugh Son, "AIG Chief Sullivan Seeks to Relax Rules on Writedowns", Bloomberg News, March 18, 2008.

Merton, Robert and Zvi Bodie, "Deposit insurance reform: a functional approach." Carnegie-Rochester Conference Series on Public Policy 38 (June), pp. 1-34. 1993. 
Miller, Merton H., "Do the M\&M propositions apply to banks?", Journal of Banking and Finance 19 (1995), pp. 483-489.

Mishkin, Frederic, "Financial Consolidation: Dangers and Opportunities", Journal of Banking and Finance 23 (1999), pp. 675-91.

Morris, Stephen and Hyun Song Shin, "Global Games: Theory and Applications", in Advances in Economics and Econometrics, the Eighth World Congress (edited by M. Dewatripont, L. Hansen and S. Turnovsky), Cambridge University Press, (2003).

Moyen, Nathalie. "How big is the debt overhang problem?." Journal of Economic Dynamics and Control 31, no. 2 (2007): 433-472.

Myers, Stewart C. "Determinants of corporate borrowing." Journal of financial economics 5, no. 2 (1977): 147-175.

Nasiripour, Shahien, “Capital Group Opposes Bank Debt Plan”, Financial Times, December 23, 2012. Oyer, Paul, "The Making of an Investment Banker: Macroeconomic Shocks, Career Choice, and Lifetime Income", The Journal of Finance 63, (December 2008), pp. 2601-2628.

Pennacchi, George, Vermaelen, Theo and Christian C.P. Wolff, "Contingent Capital: The Case for COERCs", INSEAD Faculty \& Research Working Paper, December 23, 2011.

Plender, John, "Make Simplicity a priority in banking", Financial Times, December 6, 2012.

Reinhart, Carmen M. and Kenneth S. Rogoff, "This Time is Different", Princeton University Press 2009. and ___ "From Financial Crisis to Debt Crisis",_American Economic Review,_August 2011, 101 (5), 1676-1706.

Rosengren, Eric S., "A U.S. Perspective on Strengthening Financial Stability”, May 24, 2011.

Securities and Exchange Commission, "SEC Approves Money Market Reforms to Better Protect Investors", Press Release, January 27, 2010.

Securities and Exchange Commission Office of the Chief Accountant, Division of Corporation Finance, "Report and Recommendations Pursuant to

Section 133 of the Emergency Economic Stabilization Act of 2008: Study on Mark-To-Market Accounting", December 30, 2008.

Sherman, Matthew, "The Alphabet Soup Explained: An Analysis of the Special Lending Facilities at the Federal Reserve", Center for Economic Policy Research, July 2009.

Shleifer, Andrei, and Robert W. Vishny. "Liquidation values and debt capacity: A market equilibrium approach." The Journal of Finance 47, no. 4 (1992): 1343-1366.

, "The Limits of Arbitrage", The Journal of Finance, Vol. 51, No. 1 (March 1997), pp. 35-55.

Simons, Henry Calvert, "A Positive Program for Laissez Faire: Some Proposals for a Liberal Economic Policy", in H.D. Gideonse, ed. Public Policy Pamphlet, No. 15, Chicago, 1934. 
Special Inspector General for Troubled Asset Relief Program (SIGTARP), "Extraordinary Assistance Provided to Citigroup, Inc.", January 13, 2011.

Standard and Poor's, "Default, Transition, and Recovery: Recovery Study (U.S.): Piecing Together The Performance Of Defaulted Instruments After The Recent Credit Cycle", December 1, 2011.

Stein, Jeremy C., "Monetary Policy as Financial Stability Regulation", Quarterly Journal of Economics, 2012, 127(1), 57-95.

Sundaresan, Suresh, and Neng Wang. "Dynamic Investment, Capital Structure, and Debt Overhang."

Available at SSRN 952540 (2006).

Sundaresen, Suresh and Zhenyu Wang, "On the Design of Contingent Capital with Market Trigger", Federal Reserve Bank of New York, Staff Report, No. 448, November 2011.

Taleb, Nassim Nicholas, "Antifragile: Things that Gain from Disorder", Random House, November 27, 2012.

Tett, Gillian, "Fool's Gold: How the Bold Dream of a Small Tribe at J.P. Morgan Was Corrupted by Wall Street Greed and Unleashed a Catastrophe", Free Press, New York, May 2009.

Tobin, James., "Financial Innovation and Deregulation in Perspective", Bank of Japan Monetary and Economic Studies, 3: 19-29. Reprinted, Y. Suzuki and H. Yomo, (eds.), Financial Innovation and Monetary Policy: Asia and the West, Tokyo: University of Tokyo Press, (1986): 31-42. 1985.

Tobin, James, "A Case for Preserving Regulatory Distinctions", Challenge, Vol. 30, No. 5, November/ December 1987, pp. 10-17.

Tornell, Aaron and Andres Velasco, "The Tragedy of the Commons and Economic Growth: Why Does Capital Flow from Poor to Rich Countries?", Journal of Political Economy, December 1992, 100 (6), 120831.

Tornell, Aaron and Philip R. Lane, "The Voracity Effect", American Economic Review, March 1999, 89 (1), 22-46.

U.S. House of Representatives, Subcommittee on Capital Markets, Insurance, and Government Sponsored Enterprises, Committee on Financial Services, "Mark to Market Accounting: Practices and Implications", March 12, 2009.

Valukas, Antoine, "Report of Antoine Valukas, Examiner in re: Lehman Brothers Holdings et al., Debtors" March 10, 2010.

Wilson, Linus. "Debt overhang and bank bailouts." International Journal of Monetary Economics and Finance 5, no. 4 (2012): 395-414. 


\section{Appendix 1: The Regulatory System, Cost of Capital, and Debt Overhang}

Assume risk-neutral pricing and a riskless interest rate of zero. A firm has existing investments that will return $\theta V$ at time $T$ and nothing before, in which $\theta$ is a random variable distributed on $[0, \infty]$ with density $f(\theta)$, cumulative density $F(\theta)$, and expectation 1 . The market value of the firm's assets is therefore $V$. Debt may be divided into a number of issues with differing priorities, but all debt, with a total face value of $D$, must be paid in full before equity is paid anything.

Let $G_{1}(D / V, \theta) \equiv \int_{D / V}^{\infty} \theta f(\theta) d \theta$ equal the fraction of firm value attributable to states of the world in which the debt is fully paid (and so equity receives a return). Let $G_{2}(D / V, \theta)=\int_{D / V}^{\infty} f(\theta) d \theta=1-$ $F(D / V)$, which is the probability that the debt will be paid in full. ${ }^{123}$ Then the total value of equity is equal to the value of the call option on the firm, $C(V, D, \theta)$, that provides investors with the value of the firm less the face value of the debt in all states where $\theta V>D$. That is, the value of the equity is area $C$ in Figure A.1, and is therefore $C(V, D, \theta)=V G_{1}(D / V, \theta)-D G_{2}(D / V, \theta)$; the total value of outstanding debt is $V\left(1-G_{1}\right)+D G_{2}$, so the average price of debt is $\bar{p}=(V / D)\left(1-G_{1}\right)+G_{2}$.

\section{INSERT FIGURE A.1 HERE}

We now make the firm a "bank" whose financing is distinguished from a "normal firm" in two ways. First, its debt is guaranteed by the government in return for a small insurance premium, $(1-p) D$, which for simplicity we assume is due to be paid the same day the debt is due. So the amount the bank receives for promising to repay $D$ is $p D$, whereas an unsubsidized firm would receive $\bar{p} D$, implying a subsidy to the bank of $(p-\bar{p}) D$. Second, the bank is constrained in its capital structure, because it must maintain a ratio of "regulatory equity" to risky assets of $h .{ }^{124}$ That is, we can think of the market value of the firm's assets as being $V=R+Z$ where $R$ is the regulatory value of the assets and $Z$ is the premium (or discount) of market value to regulatory value. ${ }^{125}$ So debt is constrained so that $p D=$ $R(1-h) .{ }^{126}$ It is reasonable to think of a higher $Z$ implying a stronger economy. The value of equity can now be written as

\footnotetext{
${ }^{123}$ If we assumed that $V$ followed geometric Brownian motion then $G_{1}$ would equal $N\left(d_{1}\right)$, and $G_{2}$ would equal $N\left(d_{2}\right)$ under Black-Scholes assumptions, in which $N(\cdot)$ is the cumulative normal distribution, $\left.d_{1}=[\ln (V / D)]+r+\sigma^{2} T / 2\right] / \sigma \sqrt{T}$ and $\left.d_{2}=[\ln (V / D)]+r-\sigma^{2} T / 2\right] / \sigma \sqrt{T}$ where $r$ is the riskless interest rate, $T$ is the time until option maturity, and $\sigma$ is the standard deviation in returns (per period). Under the Black-Scholes formula an option would have a value of $V N\left(d_{1}\right)$-D $e^{-r t} N\left(d_{2}\right)$.

${ }^{124}$ We might think of this as the bank's "stress test" equity requirement which may exceed its statutory requirement.

${ }^{125}$ So the market value of the firm is $R+Z+(p-\bar{p}) D$, reflecting the value of the insurance subsidy of $(p-\bar{p}) D$; the market value of the firm's equity is $R+Z-\bar{p} D$.

${ }^{126}$ That is, if a firm borrows 98 today and promises to pay back 100 in the future its debt for regulatory purposes is the amount it borrowed, 98 , even if the riskless rate is zero. One reason this accounting is used in practice is that to use the present value of promised riskless repayments would create an incentive to borrow short instead of long.
} 


$$
\begin{gathered}
C(R+Z, R(1-h) / p, \theta) \\
=-G_{2} \frac{R(1-h)}{p}+(R+Z) G_{1} \\
=(R+Z) \int_{[R(1-h) / p] /(R+Z)}^{\infty}\left[\theta-\frac{R(1-h) / p}{R+Z}\right] f(\theta) d \theta
\end{gathered}
$$

Now assume that the bank has the opportunity to make a small (e.g. \$1) new zero net present value investment (so $Z$ will remain constant). For regulatory purposes the new investment will be valued at cost, so it must be financed out of $h$ dollars of equity sold at the market price and $(1-h)$ of debt sold at $p$, assuming that the capital requirement is a binding constraint. We begin by assuming that the returns from new investments are perfectly correlated with those from old investments and are also distributed according to $\theta$.

To find the incentive for existing shareholders to make this small investment we can differentiate (3) with respect to $R$ and then subtract $h$ (the value received by the new equity investors for their shares). The result is

$$
\begin{aligned}
\frac{\partial}{\partial R} C(R+Z, & \left.\frac{R(1-h)}{p}, \theta\right)-h \\
& =-h+\int_{[R(1-h) / p] /(R+Z)}^{\infty}[\theta-(1-h) / p] f(\theta) d \theta \\
& =-h-\frac{(1-h)}{p} G_{2}+G_{1}
\end{aligned}
$$

The intuition is that the three terms on the right hand side of the last line are, respectively, (1) the dilution of old shareholders in order to raise $h$ from new shareholders; (2) the increase in the promised amount of debt repayment, $(1-h) / p$, required to raise $(1-h)$ in funds from debt-holders, times the probability, $G_{2}$, that all the debt, and therefore the marginal debt issued, will be repaid; and (3) the fraction of returns from the new investment that will be earned in states where the firm does not default and so the shareholders are the marginal beneficiary, $G_{1}$.

If insurance is fairly priced and $Z=0$, then $p=\bar{p}=\left(1-G_{1}\right)(V / D)+G_{2}=\left(1-G_{1}\right)\left(\frac{R}{R(1-h) / p}\right)+G_{2}$, which yields $p=G_{2}(1-h) /\left(G_{1}-h\right)$, and substituting into the right-hand side of (4) shows that the net return to equity of $\$ 1$ of new zero net present value investment is then zero. So if the regulatory value of assets equals the market value, insurance is fairly priced, and under our assumption that new investments are as risky as old, then the regulatory system will not distort investment, and the bank will be indifferent about making zero net present value loans. ${ }^{127}$

${ }^{127}$ If insurance is fairly priced but $Z \neq 0$, then $p=\bar{p}=\left(1-G_{1}\right)(V / D)+G_{2}=\left(1-G_{1}\right)\left(\frac{R+Z}{R(1-h) / p}\right)+G_{2}$, so $p=G_{2}(1-h) /\left(G_{1}-h-Z\left(1-G_{1}\right) / R\right)$, and (4) then implies the net return to equity of $\$ 1$ of new zero-NPV investment is $Z\left(1-G_{1}\right) / R$ which has the same sign as $Z$. When $Z$ is positive, an expansion of 
Now, however, assume the price of insurance is fixed at $1-p$ which we will assume is relatively low. We can confirm that the average insurance subsidy per dollar of debt, $p-\bar{p}$, is negatively related to $Z$ because the unsubsidized price of debt $\bar{p}$ rises with $Z .{ }^{128}$ More interestingly, differentiating (4) with respect to $Z$ yields

$$
\frac{\partial^{2}}{\partial Z \partial R} C\left(R+Z, \frac{R(1-h)}{p}, \theta\right)=\frac{-(1-h)^{2} R Z}{p^{2}(\mathrm{R}+\mathrm{Z})^{3}} f\left(\frac{R(1-h)}{p(R+Z)}\right)
$$

which has the opposite sign to $Z$, so the marginal incentive to invest, $d C / d R$, is maximized at $Z=0$. That is, while the average value of insurance per dollar of existing debt always rises as asset prices fall (because $\bar{p}$ rises with $Z$ ), the marginal incentive to make new investment is maximized when $Z=0$, when it equals $p-\bar{p} \cdot{ }^{129}$ As $Z$ rises above zero, the subsidy to investment falls, creating a counter-cyclical effect as we go from "normal" times where regulatory and market values are similar to "good" times where market values exceed regulatory values. ${ }^{130}$ However, we get a pro-cyclical effect when $Z$ falls below 0.131 Unlike the fair insurance case there is still a net subsidy to marginal investment when $Z$ begins to fall below 0 , essentially because new borrowing is available at a subsidized price; although the subsidy per dollar of investment is reduced by new investment when $Z<0$, the number of dollars of debt to which the subsidy is applied increases. ${ }^{132}$ But the marginal subsidy becomes progressively smaller, and at low enough values of $Z$ becomes negative (approaching $-h$ as $Z \rightarrow-R$ ), the circumstance referred to as "debt overhang". Figure A.2 illustrates.

equity and debt in the ratio $h /(1-h)$ reduces the firm's market ratio of equity to debt, so if insurance were priced properly, marginal insurance will be provided too cheaply, creating an investment incentive. The argument for negative $Z$ is parallel.

${ }^{128}$ That is, $\partial \bar{p} / \partial Z=\left(1-G_{1}\right) / D>0$.

${ }^{129}$ The literature on how "debt overhang" deters high-debt firms from issuing more equity and from making good low-risk new investments began with Myers (1977), and a sampling of subsequent important contributions includes Shleifer and Vishny (1992), Lamont (1995), Sundaresan and Wang (2006), Moyen (2007), Diamond and He (2012), Wilson (2012), and Admati et al (2013). Our contribution is to show how regulatory mismarking of asset prices and risk can create a system that is mildly countercyclical in good times while being both expensive and pro-cyclical in bad times.

${ }^{130}$ The reason is that when $Z>0$ an increase in $Z$ decreases the cutoff value of $\theta,(R(1-h) / p(R+$ $Z)$ ), beyond which the shareholders receive the net returns of $\theta-(1-h) / p$ but, because $Z>0$, $\theta-(1-h) / p<0$ in these marginal additional cases, so shareholders' marginal incentive is reduced by an increase in $Z$, implying a counter-cyclical incentive effect.

${ }^{131}$ Paralleling the previous footnote, the reason is that when $Z<0$ a decrease in $Z$ increases the cutoff value of $\theta,(R(1-h) / p(R+Z))$, beyond which the shareholders receive the net returns of $\theta-(1-$ $h) / p$ and, because $Z<0, \theta-(1-h) / p>0$ in these marginal additional cases so shareholders' marginal incentive is reduced by a decrease in $Z$, implying a pro-cyclical incentive effect.

${ }^{132}$ When $Z=0$ shares sell at a premium to book value because of the insurance subsidy. There will continue to be a marginal subsidy at least until $Z+(p-\bar{p}) R(1-h) / p=0$, which is where shares would sell for book value. The reason is that when shares sell for book value investment can be financed by proportionally increasing both debt and shares outstanding. If a new investment is zero net present value (and proportional in risk to old investments) this will have to raise share price because the average market value of assets per share would rise while the average debt per share would remain constant. Since the new investment is zero net present value and insured bondholders are unaffected the gain in shareholder wealth exactly equals the marginal insurance subsidy. 


\section{INSERT FIGURE A.2 HERE}

Finally, we consider the impact on both shareholder value and marginal incentives to invest due to changes in the riskiness of old and new investments--as discussed in the main text, a decline in asset values may make old loans riskier even as the riskiness of new loans does not change.

Obviously, the value of equity rises if old investments become riskier while their value stays the same, because the total (or average) value of subsidized insurance rises (the value of unsubsidized debt falls). It is also straightforward that if we hold constant the riskiness of old investments, and reduce the risk of new investments, then the incentive to make new investments declines because the marginal insurance subsidy on the new investment is lower. ${ }^{133}$

However, an increase in the riskiness of old loans (holding their value constant), while new loans retain historic risk characteristics, may reduce the incentive to make new marginal loans.

To model a difference in riskiness of new and old investments, we can think of new investment as generating returns distributed according to $f(\theta)$, as before, but old investments returns' being distributed according to $\tilde{f}(\psi)$, in which $\psi$ has the same expectation as $\theta$, but is riskier than it in terms of second-order stochastic dominance (so $\int_{0}^{D / V} \psi \tilde{f}(\psi) d \psi<\int_{0}^{D / V} \theta f(\theta) d \theta$ for all $D / V<\infty$ ). For simplicity we assume that a higher value of $\psi$ implies a higher value of $\theta$, so we can write $\theta$ as a function of $\psi, \theta(\psi)$. The marginal return to shareholders from selling debt and equity to finance a new investment (that is, increasing $R$ ) is now (cf. equation (4))

$$
-h+\int_{[R(1-h) / p] /(R+Z)}^{\infty}[(\theta(\psi)-(1-h) / p] \tilde{f}(\psi) d \psi
$$

That is, we have the usual dilution effect of $-h$ but with the shareholders' returns changed by $\theta-(1-h) / p$ per dollar of new investment in all states in which $\psi>\frac{D}{V}=(R(1-h) / p) /(R+Z)$ (which are now the states in which the firm generates enough wealth to fully pay its debt) rather than in the states in which $\theta>(R(1-h) / p) /(R+Z)$.

We can now see whether the incentive for a new investment will rise or fall when old risk is increased by comparing (6) with (4): when old and new investment returns are distributed identically, and also $Z=0$,

\footnotetext{
${ }^{133}$ For example, consider a small new investment that will return $\alpha+\beta \theta, \alpha, \beta>0$; that is, it has net present value $\alpha+\beta$, but is $\beta /(\alpha+\beta)<1$ times as risky as the average current investment per dollar of present value; shareholders' gross return (i.e., ignoring the cost of raising the funds for the investment) will be $\alpha G_{2}+\beta G_{1}$. Since $G_{1}>G_{2}$ (in Fig. A1, $G_{1}=(\mathrm{B}+\mathrm{C}) /(\mathrm{B}+\mathrm{A}+\mathrm{C})>\mathrm{B} /(\mathrm{B}+\mathrm{A})>$ $\left.G_{2}\right), \quad \alpha G_{2}+\beta G_{1}<(\alpha+\beta) G_{1}$ which would be shareholders' gross return from an investment returning $(\alpha+\beta) \theta$, that is, an investment with equal net present value to the investment under consideration, but with the same amount of risk per dollar of returns as old investment. In general, shareholders' gross returns from marginal investment will be the fraction of those returns earned in the states where debt is repaid in full, so if higher returns on old investment imply higher returns on new investment then, holding net present value constant, the riskier the new investment is in terms of second-order stochastic dominance, the greater the marginal returns for shareholders.
} 
shareholders receive a net return on a new investment (ignoring the constant dilution cost of $h$ ) whenever returns per dollar invested, $\theta$, exceed $(1-h) / p$. Then a decrease in the probability of full repayment below $\int_{(1-h) / p}^{\infty} f(\theta) d \theta=G_{2}((1-h) / p)$ means that there are cases in which $\theta(\psi)>$ $(1-h) / p$, but the benefit of the excess returns goes to creditors, making shareholders worse off. But an increase in the probability of full repayment above $G_{2}$ means that the firm avoids default (and shareholders receive net returns from new investment) in some states where $\theta(\psi)<(1-h) / p$, also making shareholders worse off. So in this case shareholders' incentive to make new investments is reduced by any change in the risk of old investments.

When $Z<0$, and new investment and old investments are equally risky, new investment adds to shareholder returns in the state where the bank is borderline bankrupt. ${ }^{134}$ So a decrease in the probability of full repayment will reduce the returns to shareholders from a new investment, just as when $Z=0$, but an increase in the probability of full repayment may either increase or decrease shareholders' incentives to invest--see Figure A.3:

\section{INSERT FIGURE A.3 HERE}

A change in the riskiness of old investment may either decrease the probability of full repayment from $G_{2}\left(\frac{R(1-h)}{p(R+Z)}\right)=1-F\left(\frac{R(1-h)}{p(R+Z)}\right)$ to $1-F_{1}$, or increase the probability to $1-F_{2} \cdot{ }^{135} \mathrm{~A}$ decrease in the probability of full repayment to $1-F_{1}$ would reduce the marginal incentive for shareholders by area $A$, the net returns in all the realizations in which the shareholders are no longer the residual claimant because full repayment is less likely. If instead the probability of full repayment increases to $1-F_{2}$ because of the greater uncertainty, then shareholders' marginal incentive is changed by area $B$ less area $C$, so whether shareholders' marginal incentive is increased or decreased depends on whether the increase in the probability of full repayment is small enough that shareholders benefit more from the incremental full debt repayment states in which $\theta(\psi)>(1-h) / p$ than they lose from the full repayment states in which $\theta(\psi)<(1-h) / p$.

So the effect of an increase in the riskiness of old investments on the incentive to undertake marginal investment, and so its effect on debt overhang, is ambiguous: it may mitigate debt overhang if the probability of the bank's failure due to greater risk increases by a small amount, but exacerbate debt overhang if the probability of the bank's failure either decreases or rises by a larger amount.

\footnotetext{
${ }^{134}$ The firm is borderline bankrupt in the state where $\theta=(R(1-h) / p) /(R+Z)$ so if $Z<0$ it must be that the marginal returns to shareholders from the new investment (ignoring dilution costs), $\theta-\frac{1-h}{p}$, are strictly positive.

${ }^{135}$ The figure is drawn for the case $Z<0$, which implies $F\left(\frac{R(1-h)}{p(R+Z)}\right)$ is to the right of $F\left(\frac{1-h}{p}\right)$.
} 


\section{Appendix 2: Valuing ERNs}

Consider a one period model of a bank that has issued common stock and $N$ outstanding issues of ERNs. Bond issue $K$ has a face value of $D_{K}$ and is convertible into $S_{K}$ shares, that is, at a price of $D_{K} / S_{K}, K=$ $1, \ldots, N$. The bank has $S_{0}$ shares outstanding, and we define $D_{0} \equiv \infty$. We assume $D_{K} / S_{K}>D_{K+1} / S_{K+1}$ for all $K$, so bond 1 has the highest conversion price and so is the most junior. ${ }^{136}$ Let the terminal value of security $K$ when the value of the bank is $V$ be $V_{K}(V)$, so for example the value of equity is $V_{0}(V)$ and the value of the most junior issue of ERNs is $V_{1}(V)$. As in Appendix 1 (but suppressing notation) let the value of a (European) call option to buy the bank at a price of $X$ when the current value is $V$ be $C(X)$, and let the value of the analogous (European) put option to sell at a price of $V$ be $P(X)$. Lastly, let $X_{K}$ be the value of $V$ at or below which security $K$ will be converted.

Debt is converted when doing this increases the value of the shares, so we can think of conversion as being chosen to maximize the firm's share price, which is equal to the value of the firm, less debt paid in cash, divided by shares outstanding, so conversion will be chosen to

$$
\max _{j}\left(\frac{1}{\sum_{i=0}^{i=j} S_{i}}\left(V-\sum_{i=j+1}^{i=N} D_{i}\right)\right)
$$

and the payoff to the owners of security $\mathrm{K}$ is the minimum of the face value of their debt $D_{K}$ and the value they would receive from $S_{K}$ shares, or

$$
V_{K}(V)=\min \left[D_{K}, \max _{j}\left(\frac{S_{K}}{\sum_{i=0}^{i=j} S_{i}}\left(V-\sum_{i=j+1}^{i=N} D_{i}\right)\right)\right]
$$

Using equation (1) we can calculate the values of the bank, $X_{K}$, at which the securities, $K=1, \ldots, N$, will convert. At the value where security $\mathrm{K}$ will be converted share price will equal $\frac{1}{\sum_{i=0}^{i=K} S_{i}}\left(X_{K}-\sum_{i=K+1}^{i=N} D_{i}\right)$ but will also equal $D_{K} / S_{K}$ since other investors are indifferent to paying off security $\mathrm{K}$ in cash or shares. ${ }^{137}$ So the value of the bank, $V=X_{K}$, at which security $K$ will convert satisfies $D_{K} / S_{K}=$ $\frac{1}{\sum_{i=0}^{i=K} S_{i}}\left(X_{K}-\sum_{i=K+1}^{i=N} D_{i}\right),{ }^{138}$ that is,

${ }^{136}$ Note that for ordinary (unsecured) debt with varying (absolute) seniority a similar analytical structure operates with $\left(D_{K} / S_{K}\right) /\left(D_{K-1} / S_{K-1}\right) \rightarrow 0$ for all $K>0$.

${ }^{137}$ An alternative derivation observes that on the date that the bonds come due the value of security $N$ is $V_{N}(V)=\min \left[D_{N}, \frac{S_{N}}{\sum_{i=0}^{i=N} S_{i}} V\right]$. So, on the same date, the value of security $N-1$ is $V_{N-1}(V)=\min \left[D_{N-1}, \max \left(\frac{s_{N-1}}{\sum_{i=0}^{i=N} S_{i}} V, \frac{S_{N-1}}{\sum_{i=0}^{i=N-1} S_{i}}\left(V-D_{N}\right)\right)\right], \quad$ and $\quad$ so on. Therefore $V_{K}(V)=\min \left[D_{K}, \max _{j \geq K}\left(\frac{s_{K}}{\sum_{i=0}^{i=j} S_{i}}\left(V-\sum_{i=j+1}^{i=N} D_{i}\right)\right)\right]$. Since the term $\max _{j \geq K}\left(\frac{S_{K}}{\sum_{i=0}^{i=j} S_{i}}\left(V-\sum_{i=j+1}^{i=N} D_{i}\right)\right)$ is maximized for $j=m$ in those states that the $m$ th and more junior, but not the $m+1$ th and more senior, 


$$
X_{K}=\frac{D_{K}}{S_{K}} \sum_{i=0}^{i=K} S_{i}+\sum_{i=K+1}^{i=N} D_{i}
$$

For example, say $S_{0}=100, S_{1}=100, S_{2}=300, S_{3}=500, D_{1}=1000, D_{2}=1500, D_{3}=1000$. Then conversion prices will be $X_{1}=4500, X_{2}=3500, X_{3}=2000$. So for example if the bank value is 3500 on the date the bonds are due, shareholders are indifferent to the conversion of bond 2: with conversion of all $D_{1}+D_{2}$ debt there are 500 shares and debt of $D_{3}=1000$, while without the conversion there are 200 shares outstanding and debt of $D_{2}+D_{3}=2500$ so, with a total bank value of 3500, the shares are worth 5 dollars each either way.

Equation (2) allows us to write $V_{K}$ either as a share of the bank's value when all debt is converted, plus and minus a set of call options, or alternatively as a fixed claim minus and plus a set of puts.

securities convert, and since security $K$ will convert prior to all more senior securities, security $K$ will convert when the value of the bank, $V$, is such that $D_{K}=\left(\frac{S_{K}}{\sum_{i=0}^{i=K} S_{i}}\left(V-\sum_{i=K+1}^{i=N} D_{i}\right)\right)$.

${ }^{138}$ Alternatively, from the equation for $V_{N}(V)$ in the preceding note, the value of the bank, $X_{N}$, at which security $N$ will convert satisfies $D_{N}=\frac{S_{N}}{\sum_{i=0}^{i=N} S_{i}} X_{N}$. So if $V>X_{N}$, then $S_{N} V>\left(\sum_{i=0}^{i=N} S_{i}\right) D_{N}=>\left(\sum_{i=0}^{i=N} S_{i}\right) V>\left(\sum_{i=0}^{i=N-1} S_{i}\right) V+\left(\sum_{i=0}^{i=N} S_{i}\right) D_{N}=>\frac{S_{N-1}}{\sum_{i=0}^{i-N} S_{i}} V>\frac{S_{N-1}}{\sum_{i=0}^{i=N-1} S_{i}}\left(V-D_{N}\right)$.

So since security $N-1$ will convert at a higher value of $V$ than $X_{N}$, the value of the bank, $X_{N-1}$, at which security $N-1$ will convert satisfies $D_{N-1}=\frac{S_{N-1}}{\sum_{i=0}^{i=N-1} S_{i}}\left(X_{N-1}-D_{N}\right)$. Hence we obtain $X_{N-1}$, etc. 
For calls,

$$
V_{K}(V)=S_{K}\left[\frac{V}{\sum_{i=0}^{i=N} S_{i}}+\sum_{j=K+1}^{j=N} \frac{S_{j} C\left(X_{j}\right)}{\sum_{i=0}^{i=j} S_{i} \sum_{i=0}^{i=j-1} S_{i}}-\frac{C\left(X_{K}\right)}{\sum_{i=0}^{i=K} S_{i}}\right]
$$

So in our numerical example the second bond can be characterized as owning a 30 percent share in the bank if the value is less than 2000, plus a call option to buy another 30 percent at a valuation of 2000 (at which price the most senior bonds, bonds 3 , are paid in full and their half ownership at the lowest values is effectively bought out by the holders of equity, bonds 1 and bonds 2 ), minus a call option for 60 percent at a valuation of 3500, at which value bonds 2 are paid in full (so they do not share in further appreciation). The value of the bond increases as a function of $V$ with a slope of .3 when $2000 \geq V \geq 0$, then a slope of .6 for $3500 \geq V>2000$, and then equals 1500 for $V \geq 3500$.

${ }^{139}$ This is easily checked by computing first $V_{N}(V)$, then $V_{N-1}(V)$, etc. For example, with $N=3$ outstanding issues of ERNs, the most senior bondholders (the owners of bond 3) effectively own $S_{3} /\left(\sum_{j=0}^{j=3} S_{j}\right)$ of the firm less the right of more-junior stakeholders to call this fraction of the firm away, which they will do when the firm is worth more than $X_{3}$, so bond 3 is worth $V_{3}(V)=\frac{S_{3}}{\sum_{j=0}^{j=3} S_{j}}(V-$ $C\left(X_{3}\right)$ ). Bond 2 also owns a share of the firm in the lowest states, increased in states in which bond 3 but not bond 2 is paid in full, and bought out in better states. More precisely, bond 2 is worth $S_{2} /\left(\sum_{j=0}^{j=3} S_{j}\right)$ of the firm plus the right to increase that share to $S_{2} /\left(\sum_{j=0}^{j=2} S_{j}\right)$ by buying out bond 3's share when share price exceeds $D_{3} / S_{3}$ and so when the firm is worth more than $X_{3}$, less the right of even-more-junior stakeholders to buy out all of those shares when share price exceeds $D_{2} / S_{2}$ and so when the firm is worth more than $X_{2}$. So bond 2 is worth $V_{2}(V)=\frac{S_{2} V}{\sum_{j=0}^{j=3} S_{j}}+\frac{S_{3} S_{2}}{\sum_{j=0}^{j=3} S_{j} \sum_{j=0}^{j=2} S_{j}} C\left(X_{3}\right)-$ $\frac{S_{2}}{\sum_{j=0}^{j=2} S_{j}} C\left(X_{2}\right)$. Similarly, bond 1 is worth $V_{1}(V)=\frac{S_{1} V}{\sum_{j=0}^{j=3} S_{j}}+\frac{S_{3} S_{1}}{\sum_{j=0}^{j=3} S_{j} \sum_{j=0}^{j=2} S_{j}} C\left(X_{3}\right)+\frac{S_{2} S_{1}}{\sum_{j=0}^{j=2} S_{j} \sum_{j=0}^{j=1} S_{j}} C\left(X_{2}\right)-$ $\frac{S_{1}}{\sum_{j=0}^{j=1} S_{j}} C\left(X_{1}\right) ;$ and equity is worth $V_{0}(V)=\frac{S_{0} V}{\sum_{j=0}^{j=3} s_{j}}+\frac{S_{3} S_{0}}{\sum_{j=0}^{j=3} S_{j} \sum_{j=0}^{j=2} s_{j}} C\left(X_{3}\right)+\frac{S_{2} S_{0}}{\sum_{j=0}^{j=2} S_{j} \sum_{j=0}^{j=1} S_{j}} C\left(X_{2}\right)+$ $\frac{S_{1}}{\sum_{j=0}^{j=1} S_{j}} C\left(X_{1}\right)$. Using (2), $X_{3}=\frac{D_{3}}{S_{3}} \sum_{j=0}^{j=3} S_{j} ; X_{2}=D_{3}+\frac{D_{2}}{S_{2}} \sum_{j=0}^{j=2} S_{j} ;$ and $X_{1}=D_{2}+D_{3}+\frac{D_{1}}{S_{1}} \sum_{j=0}^{j=1} S_{j}$. Of course, summing over all the claims, the total value is $V$. 
For puts,

$$
V_{K}(V)=D_{K}+S_{K}\left[\sum_{j=K+1}^{j=N} \frac{S_{j} P\left(X_{j}\right)}{\sum_{i=0}^{i=j} S_{i} \sum_{i=0}^{i=j-1} S_{i}}-\frac{P\left(X_{K}\right)}{\sum_{i=0}^{i=K} S_{i}}\right]
$$

So in our example, the second bond can also be described as the combination of a riskless security worth 1500 , short a put option requiring the bondholders to purchase 60 percent of the bank at a price of 3500 , so take 60 percent of the loss as $V$ falls below 3500, plus a put option allowing the bondholders to sell 30 percent of the bank to the senior (third) bondholders at a valuation of 2000 . This describes the value of the bond as 1500 when $V \geq 3500$, declining at a slope of . 6 until it reaches a value of 600 when $V=2000$, and declining at a slope of .3 thereafter until $V=0$.

Issuing ERNs to finance new investment with average risk must increase the value of equity (if new investment is zero net present value) because a proportional debt financing at all seniorities, plus a proportional equity financing, would make shareholders equally well off, and the switch to disproportionately more debt financing as well as the shift to cheaper, more senior debt both benefits equity. In our example the issuance of senior debt issue 3, when 1 and 2 are outstanding, must be beneficial for equity and must be costly to bond issue 2 , which has its seniority reduced. The most junior bonds, bond issue 1, may either gain or lose depending on whether they are effectively more like equity or bond issue 2 .

We can use our numerical example to illustrate how ERNs affect stock prices by assuming a distribution of returns on investment and comparing the case in which the bank has sold only the bonds convertible at 5 and 10 dollars per share with the case in which it can raise additional money for a zero net present value investment financed by bonds convertible at 2 dollars per share. As in Appendix 1, we assume that the riskless rate is zero, investors are risk-neutral, and all investments produce returns that are perfectly correlated and drawn from a uniform distribution starting at zero, so a zero net present value investment will return between 0 and 2 .

Say that prior to the senior bonds being issued the bank has a total value of 3125 , so returns that will be uniformly distributed between 0 and 6250 . At a realized firm value of 2500 or below, all bonds will be converted so 500 shares will be outstanding at a price of 5 or less. At a realized value between 2500 and 3500, stock price will be between 5 and 10 and only the junior bonds will be converted, while in the

${ }^{140}$ This formula can be developed by a parallel argument to that for equation (3), starting by computing first $V_{N}(V)$, then $V_{N-1}(V)$, etc., so, for example, the most senior bond is worth $D_{N}$ minus the value of the right of the other stakeholders to put shares to it. Or, of course, equation (5) can be developed directly from equation (3) by using put-call parity: $V+P(X)=X+C(X), \forall X$.

For example, with $N=3$, the value of the senior debt is $D_{3}-\frac{S_{3}}{\sum_{j=0}^{j=3} S_{j}} P\left(X_{3}\right)$; the value of intermediate debt is $D_{2}-\frac{S_{2}}{\sum_{j=0}^{j=2} S_{j}} P\left(X_{2}\right)+\frac{S_{3} S_{2}}{\sum_{j=0}^{j=3} S_{j} \Sigma_{j=0}^{j=2} S_{j}} P\left(X_{3}\right)$; the value of junior debt is $D_{1}-\frac{S_{1}}{\sum_{j=0}^{j=1} S_{j}} P\left(X_{1}\right)+$ $\frac{S_{2} S_{1}}{\sum_{j=0}^{j=2} S_{j} \sum_{j=0}^{j=1} s_{j}} P\left(X_{2}\right)+\frac{S_{3} S_{1}}{\sum_{j=0}^{j=3} s_{j} \sum_{j=0}^{j=2} S_{j}} P\left(X_{3}\right) ;$ and the value of equity is $V-\sum_{j=1}^{j=3} D_{j}+\frac{S_{1}}{\sum_{j=0}^{j=1} s_{j}} P\left(X_{1}\right)+$ $\frac{S_{2} S_{0}}{\sum_{j=0}^{j=2} S_{j} \sum_{j=0}^{j=1} S_{j}} P\left(X_{2}\right)+\frac{S_{3} S_{0}}{\sum_{j=0}^{j=3} S_{j} \sum_{j=0}^{j=2} S_{j}} P\left(X_{3}\right)$. (The values of $X_{1}, X_{2}, X_{3}$ are as in the previous note.) 
range from 3500 to 6250 all bonds are paid in full. In this case the value of the bonds convertible at 5 will be $(2500 / 6250)(750)+(3750 / 6250)(1500)=1200$. The bonds convertible at 10 will be worth $(2500 / 6250)(250)+(1000 / 6250)(750)+(2750 / 6250)(1000)=660$. The total value of outstanding equity will be $(2500 / 6250)(250)+(1000 / 6250)(750)+(2750 / 6250)(2375)=1265$.

The bank could raise $\$ 875$ of new senior bonds convertible into 500 shares at $\$ 2$ per share to invest in zero net present value projects that would increase the distribution of the firm's payoffs from 0 to 8000 . In this case the senior bonds convertible at \$2 per share (which would happen when the realized firm value was 2000 or less) would be $(2000 / 8000)(500)+(6000 / 8000)(1000)=875$. The value of bonds convertible at $\$ 5$ would fall to $(2000 / 8000)(300)+(1500 / 8000)(1050)+(4500 / 8000)(1500)=1115.625$. The bonds convertible at $\$ 10$ would now be worth $(2000 / 8000)(100)+(1500 / 8000)(350)+(1000 / 8000)(750)$ $+(3500 / 8000)(1000)=621.875$. Equity would rise in value to $(2000 / 8000)(100)+(1500 / 8000)(350)$ $+(1000 / 8000)(750)+(3500 / 8000)(2750)=1387.50 .{ }^{141}$ In this case both of the previously issued bonds decline in value when new debt is issued, but while the most senior debt before a new senior issue must lose priority and so value, the most junior previously issued debt may, in general, either rise or decline in value.

In a multi-period model the relative seniority of bonds that convert at a lower price is mitigated because some short term debt convertible at a higher stock price may be de facto senior to longer-term debt convertible at a higher price. However, our restrictions on repayment schedules ensure that new bonds can be issued with a term structure that is at least as short as outstanding debt, so that when stock prices have gone down firms can issue new bonds that are on the whole senior to existing risky debt.

\footnotetext{
${ }^{141}$ By contrast, if the firm raised the same 875 in the form of equity the firm would be required to sell 72.6468 shares and the value of existing equity would fall to $\$ 1204.46$. The cost of selling new equity would be even greater if outstanding bonds were not in the form of ERNs, since conventional debt receives absolute priority over new equity while ERNs share with equity in the worst states.
} 


\section{Appendix 3: Potential Treatment of Derivatives}

There are two competing problems in derivatives regulation. First, counterparties wish to be protected against a failure that may leave them with unsecured claims and lost hedges that are costly to replace. Second, if counterparties are able to over-state their claims, or are allowed to grab extra collateral that effectively improves their seniority, then other unsecured creditors of the firm may be subject to large losses in the unwinding of a derivatives book.

Part of the first problem, in particular, has been addressed by requiring the clearing of commonly traded derivatives. Implicit in the requirements of the central counterparty clearing house (CCP) will be to assure that when a party fails its positions can be transferred at a cost that generally does not exceed the margin posted, with the CCP holding back-up claims against the failing party, the assets of the clearing house and the CCP's owners. For these contracts we can rely on CCPs to set margins, as on secured debt, with any residual claim against a party that fails payable (at the option of the failing party) in ERNs. While this system still leaves unsecured creditors at risk from a derivatives fire sale (e.g. Lehman's Chicago Mercantile Exchange positions were liquidated at prices that were about $\$ 1.2$ billion below the previous close ${ }^{142}$ ) there should be better protection in our system because of the isolation of risks (i.e. a loss in another part of the bank cannot cause a bankruptcy) as well as the ability to pay in ERNs. Bankruptcies followed by the sudden liquidation of positions would be replaced by increased collateral demands against firms that are under stress.

To protect against counterparty risk in OTC derivatives counterparties have been requiring banks to agree to tri-party clearing, with initial margin placed with the third party and variation margin either moving directly between the counterparties or through the third party. ${ }^{143}$ In addition, regulatory capital requirements on OTC derivatives will be imposed. While beyond the scope of this paper we suggest that in our system it will be possible to design the system in a way that can leave the amount of initial margin up to private investors while limiting the impact of derivatives losses on other creditors.

For example, say that a tri-party contract specified the initial margin ${ }^{144}$ (greater than or equal to zero) posted by both parties, a "model" for valuation that determined variation margin ${ }^{145}$, a termination fee if either party did not post required variation margin and so went into default ${ }^{146}$, and conditions under which a party's initial margin would be increased. If a party defaulted on posting its variation margin it would be liable to pay what it owed, including its termination fee, but would have the right to pay in ERNs. If initial margin rose a firm would have the option of posting the additional funds or offering to

\footnotetext{
${ }^{142}$ See Valukas (2010), p. 1842.

${ }^{143}$ Our focus here is on derivatives where the two counterparties are independent, not where they are, for example, subsidiaries of the same firm.

${ }^{144}$ For a derivatives contract with an initial value of zero the "initial margin" is the amount each party would have to post as collateral upon the initiation of the contract. "Variation margin" is the increase or decrease in the amount a party posts as the value of its position changes. For example, A and B could both initially post 10 with the third party. If the value of the contract then changed by 5 in favor of $A$ then $B$ would have to post an additional 5 in variation margin while A could withdraw 5.

${ }^{145}$ The parties could choose a simple model, even specifying a constant net value of zero if they wished.

${ }^{146}$ Regulators might choose to limit termination fees, for example by requiring that initial margin be at least some percentage of any such fees. Termination fees may be different for the two parties.
} 
cancel the contract without having to pay a termination fee. ${ }^{147}$ The counterparty could then either cancel, leaving one party to owe cash or ERNs to the other, or agree to (permanently) waive the increased margin requirement. In this way a firm that was asked to post additional funds could eliminate contracts at no cost (relative to the "model" price), effectively allowing it to sell out at the price that determined its capital requirement. This eliminates the possibility of distress sales at prices worse than model prices because of a request for additional initial margin --- a potentially more difficult problem with an illiquid custom derivative than with a more liquid exchange-traded derivative. Effectively, we take advantage of the fact that the sum of the counterparties' positions is worth zero. ${ }^{148}$

As an example, prior to the Lehman bankruptcy Nomura had posted \$248 million in collateral with Lehman. After Lehman's filing Nomura submitted a claim for $\$ 722$ million, ultimately settled by giving Nomura a $\$ 250$ million claim. In our system Nomura would have only had a claim against Lehman for the part of the $\$ 248$ million that it had posted, if any, that represented initial margin. If Nomura believed that its position were worth considerably more than the amount that determined its variation margin then it would have thought of itself as an unsecured creditor of Lehman for the difference, and would have had the option to hedge that risk. Lehman's other creditors would have received a higher payoff if Nomura and other derivatives creditors had to accept lower claims. ${ }^{149}$

Firms would face a trade-off in negotiating with counter-parties for higher margin requirements and taking more counter-party risk (through possible payment in ERNs that might not be salable at face value) but possibly getting a better price, with the difference available to hedge counter-party risk if desired. The inability to insist on extra collateral when a counter-party became weaker, without the counter-party being able to cancel the contract without penalty, would push firms towards asking for more initial margin at the start of a contract. The combination of the known zero total value of derivatives contracts and the ability to terminate at the market price would make difficult-to-value contracts effectively liquid (with termination fees serving as bid-ask spreads).

${ }^{147}$ If a party owed both additional variation margin and initial margin we would think of payments as first being applied to variation margin, so if a firm paid all additional variation margin owed but chose not to pay additional initial margin it would exit the contract without penalty.

${ }^{148}$ That is, resolving the default of a loan against an illiquid asset is difficult because the value of the asset is difficult to measure. With derivatives, the total value for the two parties is zero and specifying an allocation based on a well-defined model price tells each party exactly what they will have contingent on a termination. Of course a firm that wishes to hedge the value of an illiquid asset with a liquid derivatives contract will still have the problem of owning an illiquid asset, but with our structure those assets will also not cause firms to collapse because of the right to pay for shortfalls with ERNs.

${ }^{149}$ We are still trying to understand the losses suffered by Lehman in the unwinding of its derivatives positions. It appears that it will collect roughly $\$ 19$ billion from derivatives assets that it had valued postbankruptcy at $\$ 27$ billion, and derivatives liabilities, which Lehman estimated at $\$ 12$ billion after the bankruptcy, are now listed as $\$ 27$ billion. The decline in asset collections reduces the value of the estate; the increase in unsecured liabilities, which will not be paid off in full, takes money from the pool that otherwise would go to non-derivatives creditors. 
Parties would have the option of bundling their bilateral contracts, treating a group of contracts as one with an aggregate collateral requirement and a total penalty for terminating all the contracts in the bundle. $^{150}$

There may be better policies for regulating derivatives --- much more work is needed. We simply wish to illustrate that in our system it will be possible to allow private parties discretion over collateral requirements for derivatives without creating the solvency risk that concerns governments.

${ }^{150}$ Of course firms would still have the option of making unsecured loans to one another in lieu of one party posting reduced collateral, but those loans would now be unbundled from derivatives contracts. The exception would be if, for example, a contract valued A's position at much more than its economic value, did not require $A$ to post much collateral in excess of the contract value, and at the same time imposed a large cancellation penalty, so that de facto A held a large unsecured loan from B. However, even this case does not appear problematic from the standpoint of tax payer risk, because if $A$ defaulted and its ERNs were worthless, B would still have a claim worth approximately its reported value. If regulators are concerned about this possibility they could address it by requiring firms to post a relatively high fraction of potential cancellation penalties. 


\title{
Table 1
}

\section{Marks of Investment Banks vs. Commercial Banks}

\author{
Relative Asset Marks of Securities Firms and Commercial Banks ${ }^{151}$
}

Bank

Commercial Real Estate Subprime CDOs

Alt-A

Bank of America

96

44

Citigroup

95

46

80

Wachovia Bank

91

58

55

Lehman Brothers

85

29

39

Morgan Stanley

75

15

35

Merrill Lynch

22

Source: Goldman Sachs (2008).

${ }^{151}$ It is of course possible, but perhaps unlikely, that commercial banks such as Wachovia Bank were simply vastly more adept in choosing their real estate, subprime, and Alt-A investments than the likes of Morgan Stanley or Merrill Lynch. 


\section{FIGURE 1: \\ Hypothetical Bank Balance Sheet during Transition}

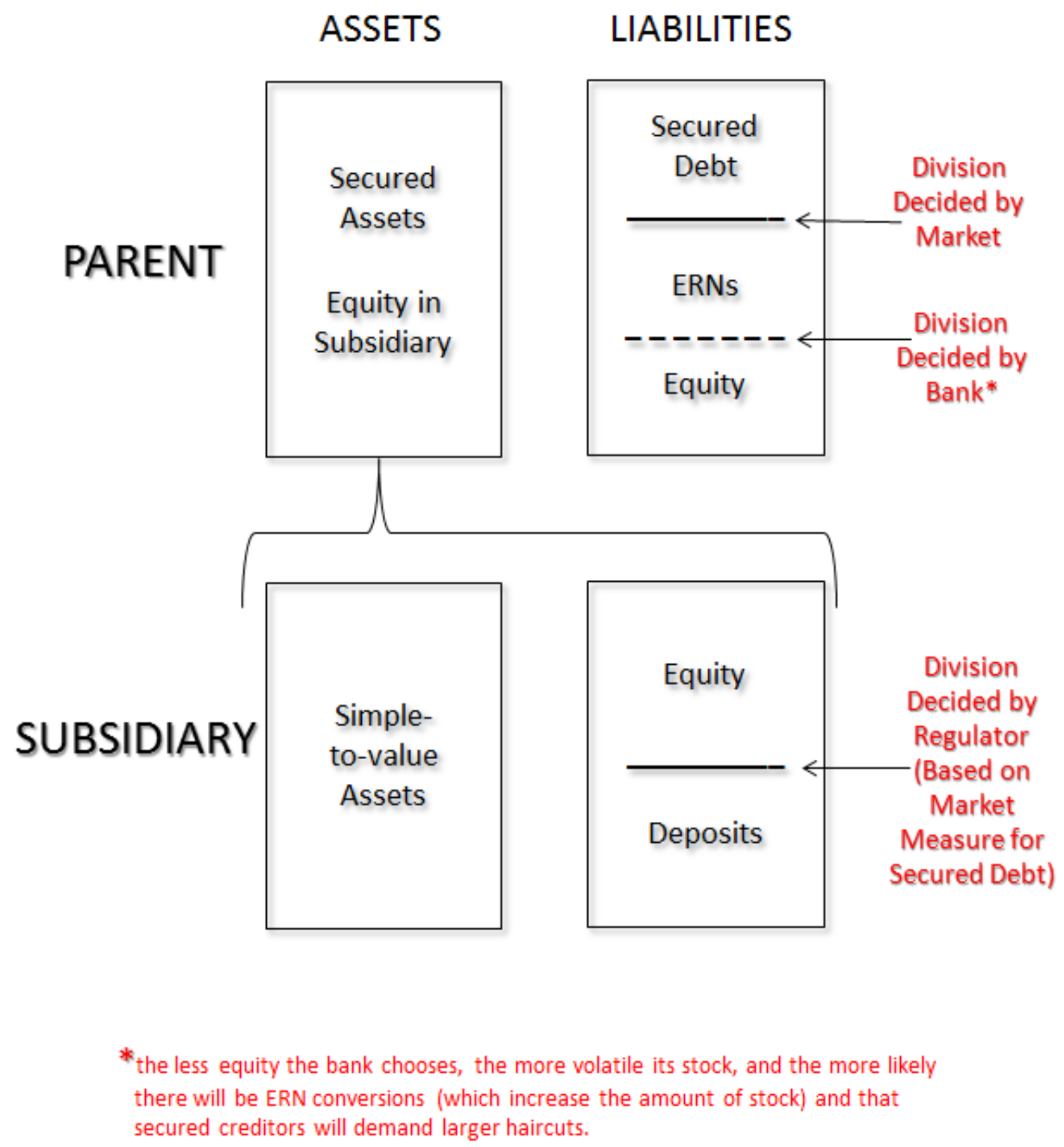


FIGURE A.1

\section{Total Returns}

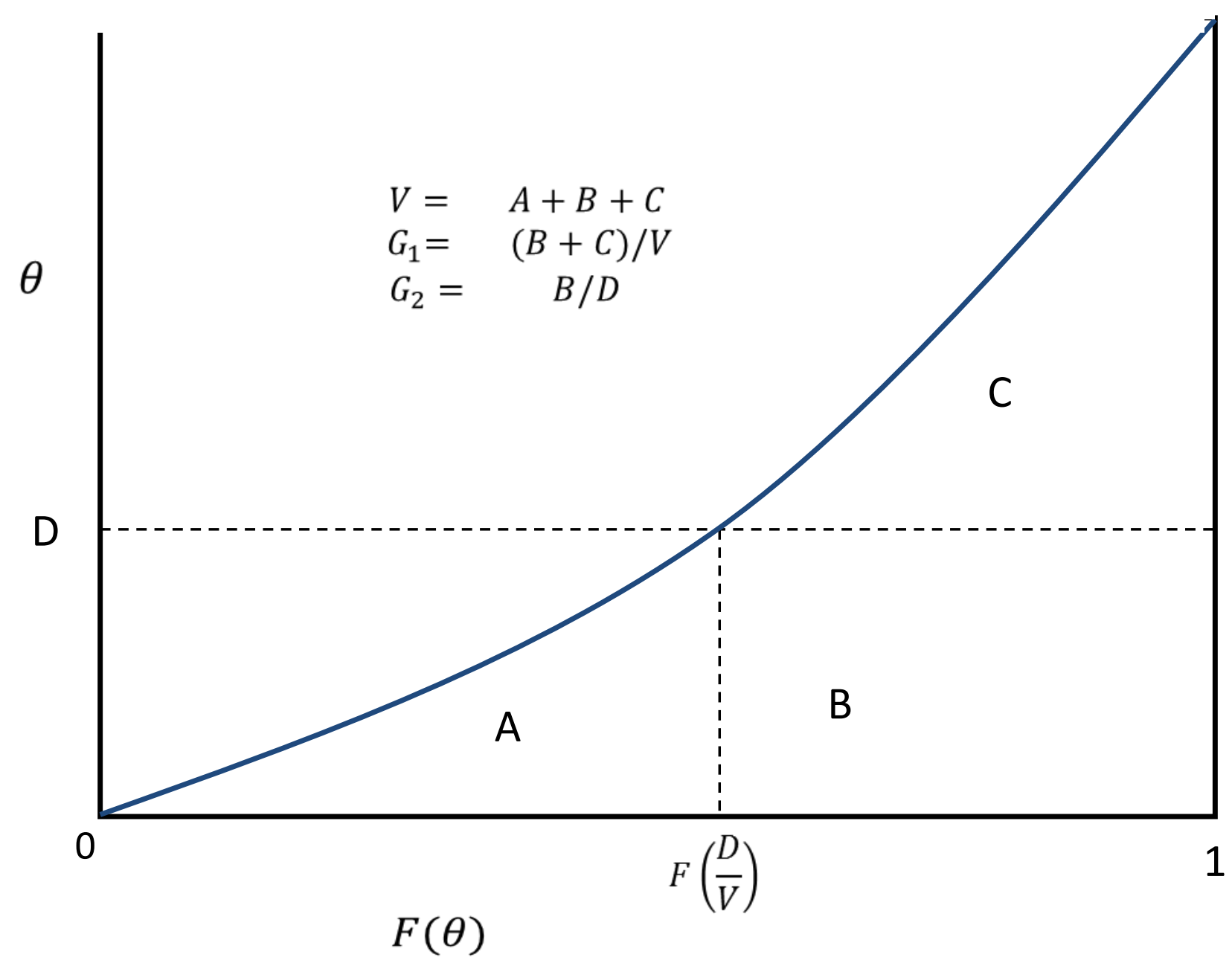

For a regulated bank

$$
V=R+Z, \quad D=R(1-h) / p
$$


Figure A.2

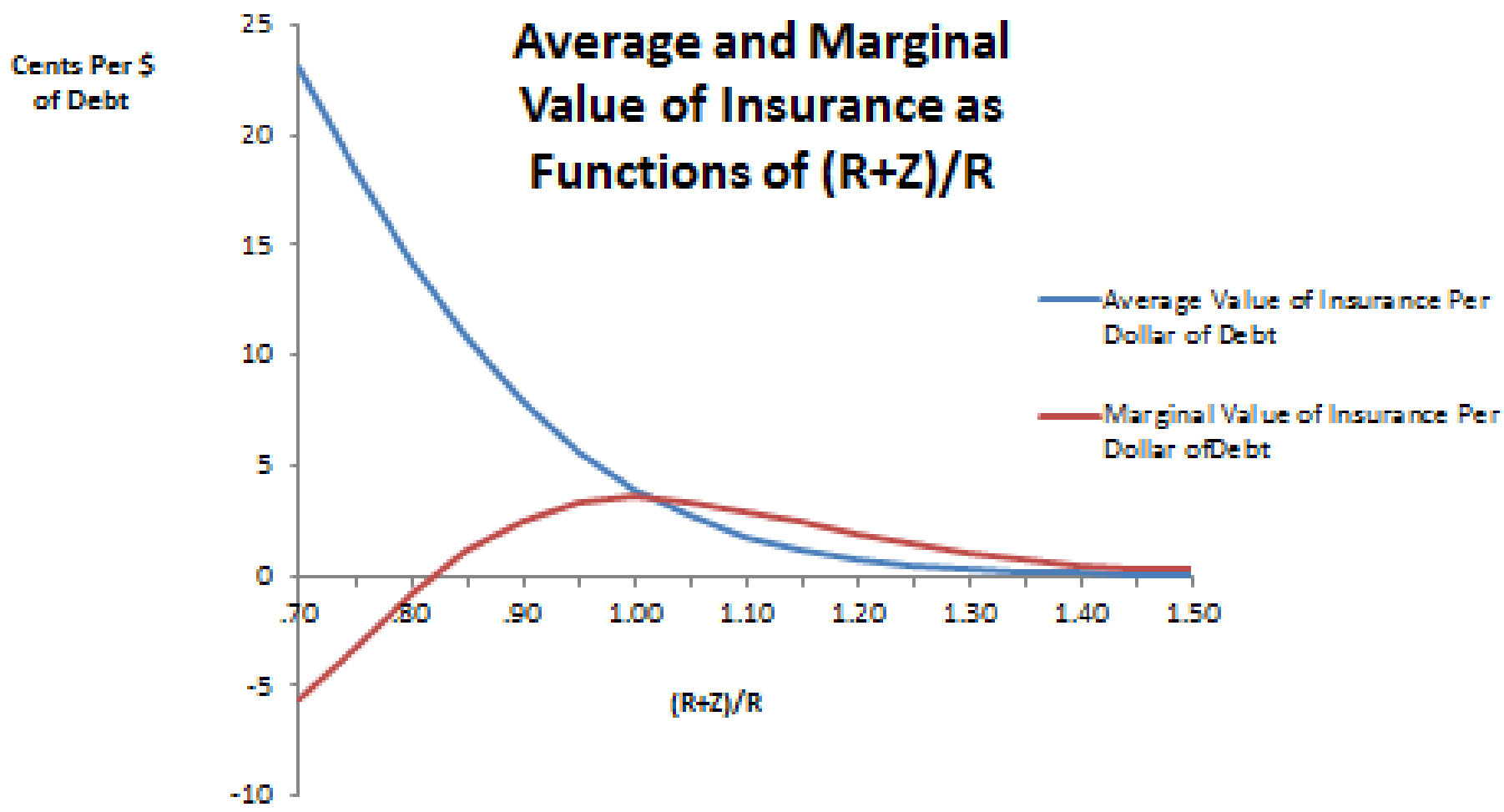

Average Value of Insurance is total value of insurance divided by total debt, measured as a percentage, that is, as cents of insurance per dollar of debt.

Marginal Value of Insurance is the increase in total value of insurance per dollar increase in debt, when capital is raised to maintain a constant ratio, $h$, of regulatory equity, $(R-D)$, to regulatory assets, $R$, also measured as a percentage, that is, as additional cents of insurance per additional dollar of debt.

The calculations in this graph are made assuming a Black-Scholes model, normalized to one period with no dividends, an interest rate of 2 percent, a volatility $\sigma=20$ percent, $p=1$ (free deposit insurance) and $h=.1$.

$Z$ is the premium (discount when negative) of the market value of the bank's assets, $(R+Z)$, to their regulatory value, $R$. 
FIGURE A.3

Marginal Returns

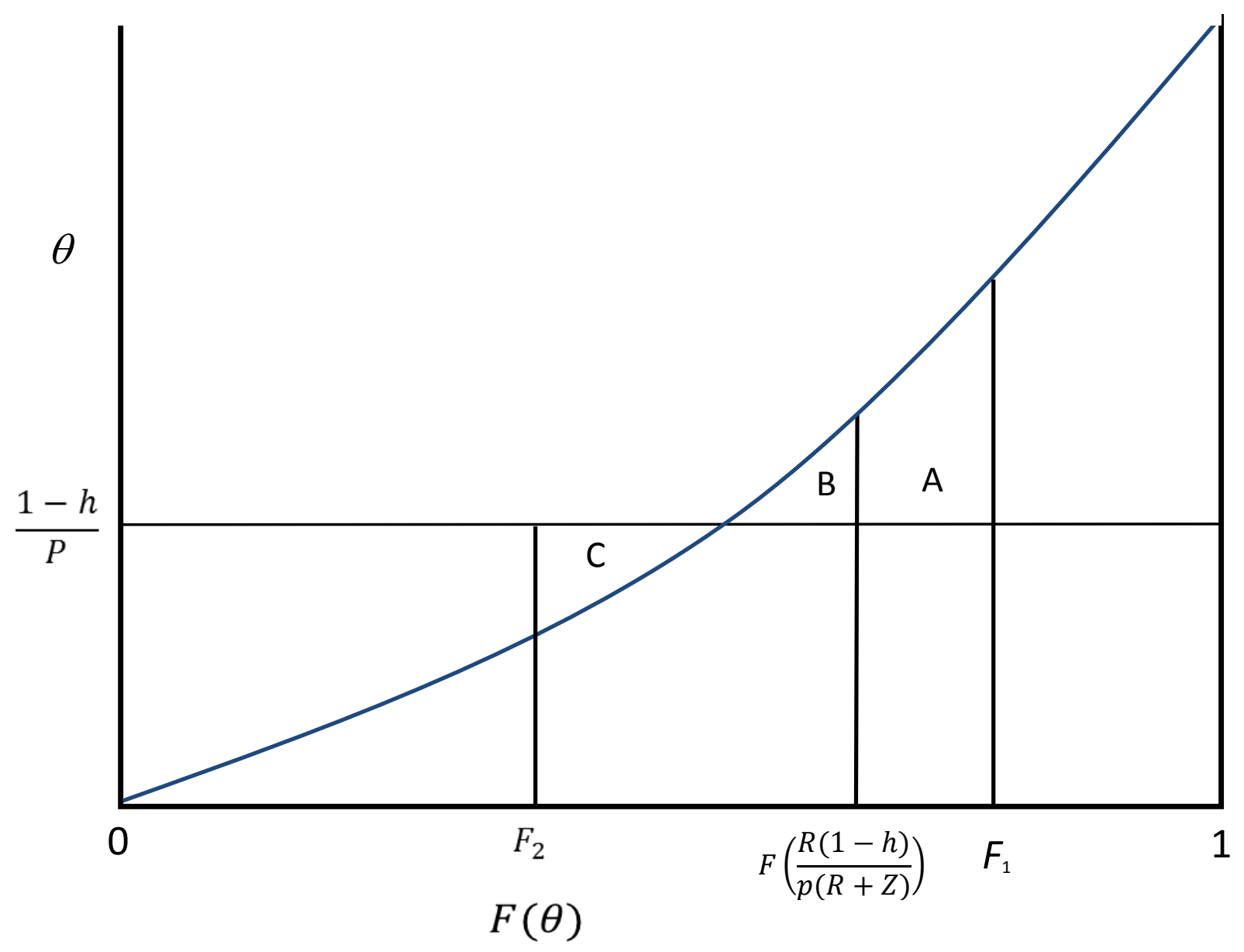

